\title{
Masako Ueda
}

\section{The Interaction}

\section{between Clause-Level}

Parameters and Context

in Russian Morphosyntax

\section{Genitive of Negation and Predicate Adjectives}

Verlag Otto Sagner München · Berlin · Washington D.C.

Digitalisiert im Rahmen der Kooperation mit dem DFG-Projekt „Digi20“

der Bayerischen Staatsbibliothek, München. OCR-Bearbeitung und Erstellung des eBooks durch den Verlag Otto Sagner:

http://verlag.kubon-sagner.de

( $)$ bei Verlag Otto Sagner. Eine Verwertung oder Weitergabe der Texte und Abbildungen, insbesondere durch Vervielfältigung, ist ohne vorherige schriftliche Genehmigung des Verlages unzulässig. 


\title{
Slavistische Beiträge
}

\author{
BEGRÜNDET VON \\ ALOIS SCHMAUS \\ HERAUSGEGEBEN VON \\ HEINRICH KUNSTMANN \\ PETER REHDER · JOSEF SCHRENK \\ REDAKTION \\ PETER REHDER
}

Band 295

\section{Busertecte \\ Stantebibllothek \\ München}


Masako Ueda

HE INTERACTION BETWEEN CLAUSE-LEVEL PARAMETERS AND CONTEXT IN RUSSIAN MORPHOSYNTAX:

Genitive of Negation and Predicate Adjectives 
ISBN 3-87690-534-6

(c) Verlag Otto Sagner, München 1992

Abteilung der Firma Kubon \& Sagner, München

Masako Ueda - 9783954791217 


\section{ACKNOWLEDGEMENTS}

I would like to thank all those who gave me encouragement, support, and advice. I am deeply indebted to Alan Timberlake who carefully read my drafts and gave me generous assistance in developing the ideas presented in this thesis. I am especially grateful for his having taken the time and patience to guide me and to teach me how to think about problems and pitfalls. I would also like to express my gratitude to Michael Flier for many useful comments and valuable advice.

There are many others who helped me produce this dissertation. I would like to thank Emily Klenin and Marianne Celce-Murcia for helpful comments on my earlier drafts, and Noriko Akatsuka for support and encouragement in the final stages of the thesis preparation. Editorial comments from Amy Copperman were also very useful. Many thanks to Karen Robblee for sharing her scanned materials with me, and to Adger Williams for helping me through some of the toughest times.

Everyone at Brown University has been extremely supportive and patient while I was finishing. I am especially grateful to Patricia Arant -- both for providing me with the necessary resources at Brown and for helping me keep things in perspective. A great thanks also to my parents for all kinds of support.

And finally, my deepest gratitude goes to Andrea and Ken with whom I have shared all the happy as well as difficult moments of life during these years. 


\section{TABLE OF CONTENTS}

Acknowledgements i

General Introduction 1

Part I. Genitive of Negation 4

Chapter 1. Preliminaries 4

1. 1. Introduction 4

1. 2. The Data Base 8

1. 3. Quantitative Results 12

Chapter 2. Clause-level Parameters 30

2. 1. Clause-level Parameters and Their Properties 30

2. 2. Interaction among the Three Types of Clause-level Parameters 40

Chapter 3. Strong and Weak Environments for Case Selection 49

3. 1. Strong Environments Triggering G 49

3. 2. Strong Environments Triggering A 58

3. 3. Weak Environments Favoring G 63

3. 4. Weak Environments Favoring A 79

3. 5. Other Weak Environments 97

3. 6. Semantics of A- and G-clauses and Their Relationship to Discourse 109

Notes to Part I 121

Appendix 1 to Part I: Existential and Individuating Verbs 124 Appendix 2 to Part I: Neutral Verbs 
Part II. Predicate Adjectives

129

Chapter 4. Preliminaries

129

4. 1. Introduction

129

4. 2. The Data Base

133

4. 3. Quantitative Results

137

Chapter 5. AS- and AN-clauses

149

5. 1. Strong Environments Triggering AS

150

5. 2. Weak Environments Favoring AS or AN

153

5. 3. Other Environments

171

5. 4. Properties of AS- and AN-clauses

176

Chapter 6. Status of AI-clauses

182

6. 1. Weak Environment Favoring AI

183

6. 2. Other Environments

186

6. 3. Conclusions to Part II

199

Notes to Part II

208

General Conclusions

212

Sources

219

References

220 


\section{LIST OF FIGURES}

Part I

Figure 1. A/G Selection and Object NP's

Figure 2. A/G Selection and Semantic Properties of the Verb

Figure. 3 A/G Selection and the Force of Negation 40

Figure 4. Strong and Weak Environments with Emphatic Negation

Figure 5. Strong and Weak Environments in the Imperfective Past and Present

Figure 6. Strong and Weak Environments with Temporalaspectual-modal Operators

Figure 7. Semantics of an A-clause

Figure 8. Semantics of a G-clause

\section{Part II}

Figure 1. Referential Uniqueness

Figure 2. Strong and Weak Environments with Complements

Figure 3. Strong and Weak Environments without Complements

Figure 4. Semantics of an AS-clause

Figure 5. Semantics of an AN-clause

Figure 6. Degrees of Automaticity in AN-AS form selection 180 
Figure 7. Semantics of an AI-clause 201

Figure 8. PA Form Selection 204

Figure 9. Addressee's Knowledge about the Subject Referent in PA-clauses 206 


\section{LIST OF TABLES}

\section{Part I}

Table 1. General and Basic Corpora 9

Table 2. Quantitatively Tested Clause-level Parameters 13

Table 3. Animate Object 14

Table 4. Proper Object 15

Table 5. Emphatic Negation 17

Table 6. Demonstrative Adjectives and Adjectives in the Neuter $\begin{array}{ll}\text { Singular } & 18\end{array}$

Table 7. The Verb Кметь 19

Table 8. Verbs of Perception and Cognition 20

Table 9. Instrumental Complement 21

Table 10. Perfective Aspect 21

Table 11. Impersonal Infinitives and Infinitives with Modal Verbs 22

Table 12. Periphrastic Future 23

Table 13. Gerund and Participle Constructions 24

Table 14. Topicalized Object (OV Word Order) 25

Table 15. Counterfactuals 26

Table 16. Exclamatives 26

Table 17. Interrogatives 27

Table 18. Imperatives 27

Table 19. Quantitative Parameters: Summary 28 
Table 20. Statistically Significant Parameters

Table 21. Classification of Verbs

Table 22. Emphatic Negation and Other Clause-level Parameters

Table 23. Imperfective Past \& Present and Other Clause-level

Parameters

Table 24. Temporal-aspectual-modal Operators (Perfective Aspect, Periphrastic Future, Counterfactuals, Interrogatives) and Other Clause-level Parameters 41

Table 25. Degrees of Automaticity in Case Selection in the Examples with Emphatic Negation

Table 26. Degrees of Automaticity in Case Selection in the Examples in the Imperfective Past \& Present

Table 27. Degrees of Automaticity in Case Selection in the Examples with Temporal-aspectual-modal Operators

Table 28. Strong Environments for Case Selection 49

Table 29. Weak Environments Favoring G 63

Table 30. Weak Environments Favoring A 80

Table 31. Other Weak Environments 98

Table 32. Individuation (IND) Operating or Different Levels110

Table 33. Existential Interpretation (EI) Operating on Different Levels 


\section{Part II}

Table 1. Excluded Examples and Examples Treated Separately

Table 2. Quantitatively Documented Parameters

Table 3. The Corpus

Table 4. Frequencies of PA-forms in the Presence of

Complements

Table 5. Frequencies of PA-forms in the Absence of Complements

Table 6. Correlation between Frequencies of PA forms and the Clause-level Parameters

Table 7. AS-AN Form Selection in Various Environments 149

Table 8. Occurrence of AI and Various Environments 183

Table 9. Semantic Properties of AS-, AI-, and AN-clauses 203 


\section{General Introduction}

Russian allows variation in many areas of morphosyntax; case selection in the object of a negated verb and form selection of predicate adjectives are two typical examples of such variation. Previous literature on these constructions suggests, on the one hand, that they are sensitive to specific contextual interpretations of the clause. Thus, for example, case selection of the object of negated transitive verbs is said to be affected by the presence of an implicit contrast between the negative situation and the corresponding affirmative (Tomson 1903), or by parameters related to informational structure of the negative clause (Morison 1964, Fuchs 1973, Timberlake 1975). Form selection of predicate adjectives is said to be affected by properties which may be expressed by context: evidentiality (Isač enko 1958, Nichols 1981), temporal-aspectual restrictions (for example, Vinogradov et al. 1960, Gustavsson 1976, Nichols 1981), referentiality of the subject NP (for example, Isačenko 1965, Babby 1975).

On the other hand, the previous literature suggests at the same time that clause-level parameters may automatically determine form. Clause-level parameters are clause-internal properties which can be objectively identified; they cun be properties of a noun phrase, of a verb, or of a whole clause. Thus, case selection of the object of the negated transitive verbs is said to be affected by a number of parameters primarily pertaining to inherent lexical properties of constituents of the negative clause which comprise 
the "individuation hierarchy" (Timberlake 1975). In predicate adjective constructions, certain clause-level parameters strongly favor one particular form: the presence of complements to predicate adjectives nearly automatically triggers the short form (Vinogradov et al. 1960, Š vedova et al. 1980); overt modal categories favor the long form instrumental case (Nichols 1981); and the subject NP without an adjunct favors the long form nominative case (Gustavsson 1976). In the present thesis I will argue that each variant in the two constructions is motivated by a specific semantic interpretation of the clause. This interpretation is generated by clause-level parameters and by context to varying degrees in different environments.

There is another issue to be addressed in conjunction with the semantic properties of the clause. Discourse-oriented studies tend to argue that morphosyntax interacts with discourse, or the manner in which various units of information are related in text. For example, Halliday and Hasan (1979) (for English) and Simmons (1981) (for Russian) describe various types of "cohesive relationships" between textual units. Givón $(1976,1983)$ argues that grammatical agreement interacts with relative topicality and topic continuity of noun phrases in discourse. Hopper and Thompson (1980), introducing the notion of "grounding", demonstrate that this discourse function of a clause correlates with properties of the clause which are considered as components of an interrelated complex called "transitivity". Discourse 
analysists such as Labov (1972) and Polanyi (1985) view that clause-internal properties, including morphosyntax, highlight the specific parts of text which carry more significant information than others. Communicative considerations are said to influence the structural choices in relative clause constructions in English conversation (Fox and Thompson 1990:315). A similar (but stronger) claim is made in García 1979:46-47 in which functional considerations are said to predict syntactic behavior. In Russian the knowledge transaction between the speaker and the addressee is said to interact with word order (Yokoyama 1986). In this thesis I will propose that the semantic property of the clause that motivates each variant in the two constructions not only provides further evidence that morphosyntactic variation can be used as discourse devices, but also suggests different manners in which morphosyntax interacts with discourse. 


\section{Part 1 . Genitive of negation}

\section{Chapter 1. Preliminaries}

\section{1. Introduction}

In Russian there is a choice between the accusative case (A) and the genitive case (G) for the object of negated transitive verbs. Previous works are based on the type of analysis which does not fully treat the effect of context, yet many of them seem to suggest that there are textual parameters involved in this case selection.

Literature indicating the relationship between context and the use of the genitive of negation, to my knowledge, goes back to Tomson (1903:218). In his interpretation of the negative sentences with $A$ and $G$, there are many statements suggestive of the role of context. For instance, in describing one of the four types of sentences with A, he states the following:

Отрищательные повествовательные предлохенна с В. П. объехта являются тогда, хогда отвергается деиствие, с уверенностью предполагаемое, ожидаемое или желаемое говорящим или слушателем.

'Negative narrative sentences with the accusative case of the object occur when an action, which is presupposed with certitude, expected, or desired by the speaker or the addressee, is rejected.' 
In other words, $A$ may be used when the corresponding affirmative is expected by the addressee or the speaker. In the following example cited by Tomson, the affirmative is what the speaker (an angel) of this utterance had wished, and thus the sentence implies that he should have "taken out the soul" ( долхен был винуть ее) (Tomson 1903:218), as directed by God.

(1) Не винул а [из родильниды] душуА.

I did not take out the soul lout of the woman in childbirth ].'

Sentences with $G$ are described by Tomson as lacking the assumption that the corresponding affirmative proposition might be possible; his observation suggests that these sentences have a descriptive rather than a narrative discourse function. Thus, (2) below is understood as a response to a question Ilохахи мне своюо нову шо шляпу! 'Show me your new hat!'. The sentence focuses on the state in which the speaker does not have a hat as a result of not having bought any (Tomson 1903:220).

(2) я не хупил шляпк .

'I did not buy a hat'

Other works also suggest the involvement of context in $A / G$ selection. The relationship between the informational structure of the negative clause and case selection has been pointed out by subsequent works. Morison (1964:293) argues that the placement of logical stress determines case selection. Fuchs (1973:87) argues 
that case selection is motivated by the types of information (new or old) which the verb and the object carry.

Possible influence of context on the use of the genitive of negation can be inferred in discussions concerning the interaction between the scope of negation and A/G selection. According to Timberlake (1975:134), scope or force of negation is one of the major factors affecting case selection. Attenuated force of negation is likely to trigger $A$, while strong force of negation extended to the object is likely to trigger G. Since scope of negation is said to interact with contextual boundness of information (Hajičová 1973:90), case selection may be conditioned by context to a certain extent.

While there are discussions suggestive of possible contextual involvement in $A / G$ selection, there are, however, also observations which suggest that case selection might be determined by clause-level parameters -- properties which can be objectively identified within the clause and have little to do with context. Jakobson (1936:38-39) seems to suggest that A or G may appear regardless of context; a case inherently has a general meaning consisting of a set of features. Although this general meaning may be subject to modifications to varying degrees when the case form occurs in specific contexts, there are no changes in terms of the presence or absence of the given features built into the case. Thus, in the object of negated transitive verbs, the $G$ form consistently has the features [+scope] and [-directionality], 
while the A form consistently has the features [+directionality] and [-scope] (where "+" signifies a positive value and "-" signifies no commitment to the value).

Previous literature on the genitive of negation lists a number of parameters which pertain primarily to inherent lexical properties of the object noun phrase: for example, parameters such as animacy, properness, modification, and concreteness of the object noun which are said to comprise the "individuation hierarchy" (Timberlake 1975:133). Thus, in the following pair, the use of $G$ in the clause with a proper noun Cement is unacceptable $\left({ }^{*}\right)$, while in the clause with a common noun роман 'the novel' it is marginally acceptable $\left({ }^{\circ}\right)$ (Timberlake 1975:124).

(3) Я еше не читала романА Гладхова «Пемент». -романаG Гладхова «Пемент».

'I have not read Gladkov's novel Cement.'

(4) Я еше не читала «Џемент»А.

$$
\text { *«Dementa»G. }
$$

'I have not read Cement.'

Lexical properties of the verb are also said to influence case selection in many sources; the verb иметь and verbs of perception and cognition are said to favor G.

Another variation on the hypothesis that $A / G$ selection is determined solely on the clause level has been put forward in Babby 1980. According to this work, there are two kinds of theme-rheme partition of a sentence, one defined by context and 
the other strictly on the clause level. It is the latter that determines the scope of negation, and thus conditions case selection of the object of the negated verb (Babby 1980:120-121).

The focus of investigation in Part $I$, then, will be to analyze the semantic properties of $A$ - and G-clauses and to examine the extent to which clause-level parameters and context generate these properties. I will also propose, on the basis of the semantic properties of A- and G-clauses, specific discourse functions which $A-$ and G-clauses are likely to have.

\subsection{The Data Base}

1732 relevant examples were collected from 2314 pages of memoiristic texts. 1 By relevant examples I mean sentences with the negative particle He placed immediately before the verb.

There are two types of corpora which I used for two different purposes: the "general" corpus, and the "basic" corpus.

The general corpus consists of all the examples with the negative particle $\mathrm{Be}$ preceding the verb; it is used to confirm the effects of the parameters tested previously in other studies. The basic corpus is the corpus which excludes impersonal constructions with infinitives, infinitives with modal verbs, imperatives, and gerund-participle constructions. My discussion will be based primarily on the basic corpus.

The distribution of $A$ and $G$ in each corpus is presented below. 
Table 1. General and Basic Corpora general compus basic corpus

$\begin{array}{lll}\text { A } & 602(34.8 \%) & 289(26.6 \%) \\ G & 1130 & 797 \\ \text { total } & 1732 & 1086\end{array}$

I excluded the following types of examples from my corpora: 1) those with constituent negation (other than the verb); 2) those with nouns showing case syncretism; 3) those with second genitive forms; 4) those with verbs which can take $G$ in positive sentences; 5) concessive clauses with the particle $H \mathrm{H}$; and 6) idioms, which I will list shortly.

\subsection{Constituent Negation}

Those examples in which the negative particle $\mathrm{He}$ does not immediately precede the verb were excluded; they obligatorily take $A$. In the example below the negative particle $\mathrm{se}$ modifies the adverbial phrase из-за стихов 'because of the poems' rather than the verb $3 а б ы л а$ '[I] forgot' or the verb phrase $3 а б ы л а$ Ирину 'forgot Irina'. Likewise, examples with object negation and subject negation were excluded.

(5) [..] но я не из-за стихов забыла ИринуА (С. 592)

'[...] but not because of poems did I forget IrinaA.'

Those sentences with masculine animate object NP's were excluded because in those nouns the accusative case and the 
genitive case have the same morphological shape both within the singular and within the plural numbers. Examples with feminine animate object NP's in the plural were also excluded for the same reason. First declension neuter nouns (of the type: genitive singular and accusative plural светила 'luminary'), second declension feminine nouns (of the type: genitive singular and accusative plural хвиги 'book'), and third declension feminine nouns (of the type: genitive singular and accusative plural тетради 'notebook'), which do not show syncretism within the same number, but rather across numbers, were included. When these nouns were not modified to indicate number, I differentiated the accusative and the genitive by eliciting the grammatical number of the object NP's from native speakers.

\subsection{Second Genitive}

Examples with a second genitive as the object of a negated verb were eliminated from the beginning. The second genitive desinence $\{u\}$ is distinct from the first genitive desinence $\{a\}$ in the masculine first declension, as in the following example.

(6) Не хочет она мне виноградуG2 дать, [... (C. 658)

'She doesn't want to give me grapes $(\mathbf{2},[\ldots]$ '

Examples of this type were excluded since the motivation for the second genitive may be different from those for the first genitive (Klenin 1978:180). 


\section{2. 4. Verbs Taking $G$ in Affirmative Sentences}

Verbs which can take $G$ in positive sentences, such as ждать 'to wait', ожидать 'to expect', просить 'to ask for', заслухивать 'to deserve' (taking $G$ only in the imperfective aspect), хотеть 'to want' were not included in the general corpus.

\subsection{Concessive Constructions with ur '..ever'}

Concessive sentences inherently convey positive meaning, and thus were excluded from the corpus.

(7) $[\ldots]$ и схоль добрые чувстваА он ни питал х мое маме, $[$...](5.209)

' $[\ldots]$ and no matter what kind feelings $A$ he nourished towards my mother, $[\ldots]^{\prime}$

(8) $[\ldots]$ и чтоА бы ничитал орлов, артиста у михрофона я не слышала. (З. 286)

'[...] and regardless of what ${ }^{A}$ Orlov read, I did not hear an artist at the microphone.'

\subsection{Idioms}

The following is the exhaustive list of the types of examples considered to be idiomatic in my corpus :

не давать/дать кому покояG 'not to give peaceG to someone'

не знать поты $\mathrm{G} \circ$ чём 'not to know an io:a $G$ about something'

не иметь праваG 'not to have the right $G$ '

не иметь понятияG 'not to have any idea'

не принимать/принять участияG 'not to take partG'

не обрашать/обратить вниманияG 'not to turn attentionG' 
не оставлять камняG на хамне 'not to leave a stoneG on a Stone [=to raze to the ground]'

не отрывать/оторвать глазG 'not to tear [one's] eyesG away'

не отводить/отвести, сводить/свести глаз 'not to turn away [one's] eyes ${ }^{\text {' }}$

не поднимать/поднять рукиG против кого 'not to raise a hand $G$ against someone'

не пророкить словаG 'not to let slip a wordG'

не говорить/сказать (ни) словаG 'not to say a wordG'

He смнкать/сомкнуть глаз ${ }^{\prime}$ 'not to close [one's] eyesG'

не ударить палең ${ }^{A}$ п палеy 'not to hit a finger $A$ against a finger [=not to raise a finger]'

не чаять душиG 'to worship'

\section{3. Quantitative Results}

This section is intended to test previous quantitative analyses of clause-level parameters. As shown in the table below, the parameters can be divided into three groups: those pertaining to the object NP, 2 those pertaining to the verb and/or verb phrase, and those pertaining to the clause. The selection of such parameters was based primarily on Restan 1960, Safarewiczowa 1960, Korn 1967, Green 1979, Haka 1981,3 and Mustajoki 1985. There has been little quantitative investigation of the effect of counterfactuals, but the correlation between this parameter and 
case selection was examined in order to test whether $A$ is preferred under attenuated negation.

\section{Table 2. Quantitatively Tested Clause-level Parameters}

I. parameters pertaining to the object NP

1) animate object NP

2) proper object NP

3) emphatic negation on the object NP

4) demonstrative adjectives and headless adjectives in the neuter singular

II. parameters pertaining to the verb and/or verb phrase

5) the verb nMeтb 'to possess'

6) verbs of perception and cognition

7) verbs taking instrumental complements

8) perfective aspect

9) impersonal infinitives, infinitives with modal verbs

10) periphrastic future

11) gerunds and participles

III. parameters pertaining to the clause

12) topicalized object NP (OV word order)

13) counterfactuals

14) exclamatives

15) interrogatives

16) imperatives 
The Yates correction factor was used for calculating the significance of parameters, in accordance with the instructions in Hatch and Farhady 1982:170-171. The significance level was set at $.05=3.84$; the parameter was considered significant if $X^{2}$ was greater than this number. When there were cells whose expected frequencies were less than 5 (and therefore this method could not be used legitimately), the Fisher exact test was employed instead. All examples were classified (positively or negatively) for the given parameter.

The descriptions of the parameters and the results from my corpus follow.

\subsubsection{Animate Object NP}

Animate object NP's are said to strongly correlate with A (Safarewiczowa 1960:124).

(9) Я не забуду -- собакуA. (C. 681)

I will not forget -- the $\operatorname{dog} A$.

The results in Table 3 confirm the significance of this parameter. The percentage of $A$ is overwhelming under animate objects; the value of $X^{2}$ is dramatically high (191.79)

Table 3. Animate Object

\begin{tabular}{lccr} 
& tanimate & -animate & total \\
\hline A & $121(89.6 \%)$ & $481(30.1 \%)$ & 602 \\
G & 14 & 1116 & 1130 \\
total & 135 & 1597 & 1732 \\
$X^{2}=191.79$ & & &
\end{tabular}




\subsubsection{Proper Object NP}

Proper object NP's appear frequently in A (Restan 1960:97). I included kinship terms (Maмa 'Mama', Папа 'Papa', Тетя 'Auntie') among these NP's.

(10) Я ве виню ВсениюА. (క. 159)

'I do not accuse Ksenija ${ }^{A}$.'

The results in Table 4 are in agreement with the previous findings. A is almost obligatory with proper objects; the value of $X^{2}$ is dramatically high (192.32)

\section{Table 4. Proper Object}

$\begin{array}{lccr} & \text { tproper } & \text {-proper } & \text { total } \\ \text { A } & 112(93.3 \%) & 490(30.4 \%) & 602 \\ \text { G } & 8 & 1122 & 1130 \\ \text { total } & 120 & 1612 & 1732 \\ X^{2}=192.32 & & \end{array}$

\section{3. 3. Emphatic Negation}

These are examples in which the object NP is modified by нихахо 'no', or the object is directly preceded by the negative particle ви as in ни..., ни... 'neither....nor' and ни однв 'not a single'.4

(11) Но я положительно не помню ни одного приянахаG Аворниха, [...]. (С. 477) 
'But I positively do not remember a single characteristic ${ }^{G}$ of the yardsman, [...]'

(12) Нихахого дохладаG он, разумеется, так и не сдөлал, (...) (Kr. 103)

'He, of course, did not present any report' $[\ldots .$.$] '$

(13) А мы не видели в төх же «Семи повешениих" ии обреченностиG, ни чисто фнзнологического страхаG смерти, [...] (Kr. 127)

'But we saw in the same "Seven That Were Hanged" neither feeling of doom ${ }^{G}$, nor purely physiological fearG for death, $[\ldots . . .]^{\prime}$

In the test results in Mustajoki 1985:159, $\mathrm{G}$ is almost $100 \%$ obligatory; others, such as Restan (1960:101) and Korn (1967:490), show extremely low percentages of $A(6 \%$ and $1.8 \%)$. Green (1979:179-180) and Haka (1981) have a higher ratio of A (23.8\% and $38.2 \%$ ), but this seems to be due to the choice of examples: Haka included those with other means of emphasis including included examples in which emphatic negation modifies constituents other than the object. The results from my corpus are in agreement with works by Mustajoki, Restan, and Korn; the frequencies in Table 5 show that the parameter of emphatic negation strongly prefers $G ; G$ is almost obligatory under this parameter, and the value of $X^{2}$ is very high (50.13). 


\section{Table 5. Emphatic Negation}

temphneg -emph.neg total

$\begin{array}{lccr}\text { A } & 6(4.9 \%) & 596(37.0 \%) & 602 \\ \text { G } & 116 & 1014 & 1130 \\ \text { total } & 122 & 1610 & 1732 \\ X^{2}=50.13 & & \end{array}$

1. 3. 4. Demonstrative Adjectives and Headless Adjectives in the Neuter Singular

This parameter has been investigated by Restan (1960:102103), who calculated the frequency of $A$ to be $9 \%$ for эт०, $15 \%$ for TO, and 23\% for ч то. I put together examples with это/зтого 'this', то/тоro (antecedent for что/чero), पто/чero 'what', мвогое/многого 'much', всё/всего 'everything', своё/своего 'his/her/its own', Одно/ОдногО 'one thing', and adjectives in the neuter singular without a head noun. These NP's tend to present abstract notions or situations.

(14) И у сестры Baше многогоG не понимаю, [...] (C. 708)

'There is a lot $G$ which I do not understand in your sister's works $[\ldots]^{\prime}$

(15) [...] будь он там, на месте Баталова или других хомандиров полков, он бы наверняха сумел сделать то, чегоG они не сделали. (S. 189) 
'[...] Had he been there, in place of Batalov 0 ' other commanders of the regiment, he would probabl, have managed to do that which ${ }^{G}$ they did not do.'

The value of $X^{2}(19.56)$ in Table 6 shows that the paraneter is significant.

Table 6. Demonstrative Adiectives and Headless Adjectives in the Neuter Singular

+neut.dem. sing, -neut dem.sing, total

$\begin{array}{lrrrr}\text { A } & 39(20.2 \%) & 563(36.6 \%) & 602 \\ \text { G } & 154 & 976 & 1130 \\ \text { total } & 193 & 1539 & 1732 \\ X^{2}=19.56 & & & \end{array}$

\subsubsection{The Verb KMets 'to Possess'}

Quantitative studies indicate that sentences with иметbalmost exclusively prefer G (Restan 1960:101, Korn 1967:491, Green 1979:185). Mustajoki's data (1985:148) also show a strong preference for $G$ in sentences with иметь, but it is also aid that other parameters such as animacy and concreteness of the object noun can block the occurrence of $\mathrm{G}$.

(16) $\mathrm{K}$ руховодству театром он прнзванияG не имел. Ц. 181) 'He did not have a calling $G$ for theater management.'

Table 7 shows that иметь strongly correlates with G; the value of $X^{2}$ is quite high (35.37). 
Table 7. The Verb usets

+ HMETb

- PMETb

total

$\begin{array}{lllr}\text { A } & 1(1.4 \%) & 601(36.2 \%) & 602 \\ \text { G } & 71 & 1059 & 1130 \\ \text { total } & 72 & 1660 & 1732 \\ X^{2}=35.37 & & & \end{array}$

\subsubsection{Verbs of Perception}

Verbs of perception and cognition are said to strongly correlate with G (Restan 1960:100, Green 1979:183, Haka 1981).

(17) [...] именG их му не знаем. (Rb. 273)

'[...] we do not know their names ${ }^{G}$.'

(18) [...] Артемьев не видел домаG, но примерно помнил, где ов его видел. (S. 58)

'[...] Artem'er did not see the house ${ }^{G}$, but remembered approximately where he had seen it.'

(19) По наивности я тогда не понял истинного смыслаG этих слов [...] (Rb. 186)

'Out of naiveté I did not understand the true meaning of these words then.'

The results from my corpus (Table 8) confirm the previous findings. $G$ is almost obligatory $(85.0 \%)$ with verbs of perception and cognition. The parameter is highly significant $\left(X^{2=79.17}\right)$. 
Table 8. Veths of Perception and Cosnition

$\begin{array}{lrrr} & \text { tperc. \& coq. } & \text {-perc. \& cog. } & \text { total } \\ \text { A } & 55(15.0 \%) & 547(40.1 \%) & 602 \\ \text { G } & 312 & 818 & 1130 \\ \text { total } & 367 & 1365 & 1732 \\ X^{2}=79.17 & & & \end{array}$

\subsection{Verbs Taking Instrumental Complements}

The presence of another complement in the instrumental zase is said to correlate with A (Restan 1960:99). I counted examples in which the verb necessarily takes a complement in the instrumental case, and those in which the instrumental signifies instrument or "means.

(20) Мои отношения А п Пашенно друхеским ве назовешь.

\section{(క. 338)}

'One cannot call my relations $A$ with Pašennaja friendly.'

(21) ИвсденировкуА, разумеется, я этим не спасла. (క. 88)

'Of course I did not save the adaptation A by this.'

The results in Table 9 confirm the previous findings: $\lambda$ is almost obligatory with an instrumental complement and the $x^{2}$ for this parameter is quite high (33.98). 
Table 2. Instrumental Complement

\begin{tabular}{lccr} 
& tcomplement & -complement & total \\
\hline A & $26(86.7 \%)$ & $576(33.8 \%)$ & 602 \\
G & 4 & 1126 & 1130 \\
total & 30 & 1702 & 1732 \\
$X^{2}=33.98$ & & &
\end{tabular}

\section{3. 8. Perfective Aspect}

Perfective aspect is said to correlate with A (Restan 1960:97, Korn 1967:491, Haka 1981).

(22) Тах что девическую талнюА мама, конечно, не сохранилаPF. (Rb. 45)

'So that Mama, of course, did not preserve ${ }^{P F}$ a girlish waist ${ }^{A}$.'

The results from my corpus (Table 10) indicate that this parameter correlates significantly with $A\left(X^{2}=39.21\right)$.

Table 10. Perfective Aspect

$\begin{array}{lllr} & +p f & -p f & \text { total } \\ \text { A } & 296(43.8 \%) & 306(29.0 \%) & 602 \\ \text { C } & 380 & 750 & 1130 \\ \text { total } & 676 & 1056 & 1732 \\ X^{2}=39.21 & & \end{array}$




\section{3. 2. Impersonal Infinitives. Infinitives with Modal Verbs}

Infinitive constructions are said to favor A (Haka 1981).

(23) Нихогда мне не забыть прехрасную галлереюА оеразов русских хенщин, созданную ею. (Ја. 79)

'I can never forget the wonderful galleryA of images of the Russian women created by her.'

(24) [..] Ленский не смог побороть стоявшие на его пути препятствия A, [...] (Ja. 109)

'[...] Lenskij could not overcome the obstacles ${ }^{A}$ which stood in his way.'

Table 11 shows the frequencies of $A$ among impersonal infinitives and infinitives with modal verbs. $x^{2}$ indicates that this parameter is extremely significant $\left(X^{2}=189.98\right)$.

Table 11. Impersonal Infinitives and Infinitives with Modal Verbs

$\begin{array}{lllr} & \text { +infinitive } & \text {-infinitive } & \text { lotal } \\ \text { A } & 278(61.4 \%) & 324(25.3 \%) & 602 \\ \text { G } & 175 & 955 & 1130 \\ \text { total } & 453 & 1279 & 1732 \\ X^{2}=189.98 & & \end{array}$

\section{3. 10. Periphrastic Future}

Examples in the periphrastic future were treated separately for measurement of significance under Table 12. 
(25) [...] если Оля не передаст его бабушке, то она больше не будет приносить продуктыА. (Rb. 223) '[...] if Olja does not relay it [the message] to Grandma, then she will no longer bring foodA.'

The results indicate that periphrastic future strongly correlates with $A$. The frequency of $A$ in the positive cell is extremely high (84.6\%); the significance level $\alpha=0.0002831$, which is much lower than .05 , indicates that the parameter is highly significant.

Table 12. Periphrastic Future tperiphr. fut. -periphr. fut. total

A

$$
11(84.6 \%)
$$

$591(34.4 \%)$ 602

G

$$
2
$$

1128 1130

total

13

1719

$\alpha=0.0002831 \ll \alpha=0.05$

\subsection{Gerund and Participle Constructions}

Quantitative works all seem to agree that the ratio of $A$ is relatively lower in gerund and participle constructions than in other contexts (Restan 1960:100, Korn 1967:490, Green 1979:178, Haka 1981).

(26) Не играя это ролй более 12 лет, Елена Митрофановна согласилась выехать и сыграть спектакль «Волки и овџы ) (క. 351) 
'Although she had not played this role $\mathrm{G}$ for more thin 12 years, Elena Mitrofanovna agreed to come over and perform the play "Wolves and Sheep".'

(27) Утром прнлетали их самолеты, бросили бомбу, ве причинившие большого вредаG [...] (Rb. 206)

'In the morning their planes flew over, and dropped bombs, which did not cause great harmG $[. . .]^{\prime}$

As shown in Table 13, I treated gerund and participle constructions together; the parameter is significant $\left(X^{2}=22.32\right)$.

Table 13. Gerund and Participle Constructions

\begin{tabular}{lccr} 
& tger. \& part. & -ger. \& part & total \\
A & $36(19.0 \%)$ & $566(36.7 \%)$ & 602 \\
C & 153 & 977 & 1130 \\
\hline total & 189 & 1543 & 1732 \\
$X^{2}=22.32$ & & &
\end{tabular}

\subsection{Topicalized Object NP (OV Word Order)}

It is not clear whether OV word order prefers A. According to works such as Magner 1955:535 and Timberlake 1975:126, topicalized object NP's are said to prefer A. Quantitative works such as Restan 1960:99 and Haka 1981 indicate that this parameter is not very significant. My corpus contained many examples with $G$ such as the one below.

(28) $[\ldots]$ названия ееG не помню, $[\ldots]$ (Rb. 142) 
'[...] its name ${ }^{G} \mathbf{I}$ do not remember, $[\ldots]$ '

The results in Table 14 suggest that this parameter is not significant; the percentages of $A$ under different word orders do not show any directionality of change. The value of $x^{2}$ is extremely low.

\section{Table 14. Topicalized Object (OV Word Order)}

$\begin{array}{lllr} & \text { +OV } & - \text { OV } & \text { total } \\ \text { A } & 195(35.8 \%) & 407(34.3 \%) & 602 \\ \text { C } & 350 & 780 & 1130 \\ \text { total } & 545 & 1187 & 1732 \\ X^{2}=0.30 & & & \end{array}$

\subsection{Counterfactual Sentences}

There has apparently been little investigation of quantitative significance of this parameter. Green (1979:172) reports three (of twelve) examples with A.

(29) $\{\ldots\rfloor$ он стал бы замечательным ахтером, если бы не предпочел профессиюА юриста. (Кr. 28)

'[...] he would have become a remarkable actor if he had not preferred the profession A of lawyer.'

My calculation is based on more examples than are found in previous works; it indicates that $A$ is preferred under this parameter (65.1\% of all the examples of counterfactuals) and that this parameter is significant $\left(X^{2}=16.58\right)$. 
Table 15. Counterfactuals

tcounterfactual counterfactual total

$\begin{array}{llll}\text { A } & 28(65.1 \%) & 574(34.0 \%) & 602 \\ \text { G } & 15 & 115 & 1130 \\ \text { total } & 43 & 1689 & 1732 \\ X^{2}=16.58 & & & \end{array}$

\subsection{Exclamatory Sentences}

$A$ is said to be preferred in interrogative and exclamatory clauses (Restan 1960:98, Haka 1981). I considered all sentences ending in an exclamation mark exclamatory, but I did not include examples where the negative clause was a subordinate clause within an exclamatory sentence.

(30) В хахом медвехьем уголхе не знали и не произвосили благоговейо имя Федотовой (Ја. 79)

'In what god-forsaken place would people not know and pronounce reverentially Fedotova's name ${ }^{A}$ !'

The results from my corpus (Table 16) do not confirm strong preference for $A$ in this environment. The parameter cannot be considered significant $\left(X^{2}=3.82\right)$.

Table 16. Exclamatives

$\begin{array}{lccr} & \text { texclamative } & \text {-exclamative } & \text { total } \\ \text { A } & 26(48.1 \%) & 576(34.3 \%) & 602 \\ \text { G } & 28 & 1102 & 1130 \\ \text { total } & 54 & 1678 & 1732 \\ X^{2}=3.82 & & & \end{array}$




\section{3. 15. Interrogative Sentences}

The results from my corpus indicate that interrogatives significantly correlate with $A\left(X^{2}=16.99\right)$.

(31) Она хе Ягудина, ту не знаешь эту семенху A? (Rb. 179)

'She is a Jagudin, don't you know this familyA?'

Table 17. Interrogatives

$\begin{array}{llcr} & \text { +interrogative } & \text {-interrogative } & \text { total } \\ \text { A } & 40(58.8 \%) & 562(33.8 \%) & 602 \\ \text { G } & 28 & 1102 & 1130 \\ \text { total } & 68 & 1664 & 1732 \\ X^{2}=16.99 & & & \end{array}$

\subsection{Imperative Sentences}

Previous quantitative works indicate that $A$ is preferred in this environment (Restan 1960:98, Korn 1967:490).

(32) Не строн из себя баришню, [...] (Rb. 85)

'Don't make a lady out of yourself, [...]'

Table 18 shows that the percentage of $A$ is in fact lower with the imperative than that in other contexts; $x^{2}$ is not high enough for this parameter to be considered significant $\left(X^{2}=1.66\right)$.

Table 18. Imperatives

$\begin{array}{lccr} & \text { timperative } & \text {-imperative } & \text { total } \\ \text { A } & 4(19.0 \%) & 598(34.9 \%) & 602 \\ \text { G } & 17 & 1113 & 1130 \\ \text { total } & 21 & 1712 & 1732 \\ X^{2}=1.66 & & & \end{array}$




\section{3. 17. Summary}

The data from my primary corpus have largely confirmed the previous quantitative findings; most of the parameters which have been said to be significant seem, indeed, to affect case selection. Below is the list of clause-level parameters and their values of $x^{2}$.

\section{Table 19. Quantitative Parameters: Summary}

1. parameters pertaining to the object NP
1) animate object NP
191.79
A
2) proper object NP
192.32
A
3) emphatic negation
50.13
G
4) neut. sing. dem. etc.
19.56
G

II. parameters pertaining to the verb or the verb phrase

5) иметь 'to possess' $35.37 \quad$ G

6) verbs of perc.\&cog.

79.17

G

7) predicate instr.

33.98

A

8) perfective aspect

39.21

A

9) infinitives

189.98

A

10) periphrastic future

$0.0002831<<\alpha=0.05$

A

11) gerunds \& participles 22.32

G

III. parameters pertaining to the clause

12) OV word order

0.30

13) counterfactuals

16.58

A

14) exclamatives

3.82

15) interrogatives

16.99

A

16) imperatives

1.66 
These parameters were treated separately, but some of them cooccur. How, then, do these clause-level parameters interact with one another? In the following sections I will examine the relationship between case selection and combinations of these clause-level parameters. 


\section{Chapter 2. Clause-level Parameters}

\subsection{Clause-level Parameters and Their Properties}

The previous section has confirmed the significance of eleven clause-level parameters which are relevant to examples in the basic corpus. They can be divided into three groups: clauselevel parameters interacting with referential uniqueness of the object, clause-level parameters interacting with semantic properties of the verb, and clause-level parameters interacting with force or scope of negation. They are listed in the table below:

\section{Table 20. Statistically Significant Parameters}

I. parameters interacting with referential uniqueness of the object

1) animacy of the object

2) properness of the object

3) demonstratives and headless adjectives in the neuter singular

II. parameters interacting with semantic properties of the verb

1) the verb rimetb

2) verbs of perception and cognition

3) verbs taking instrumental complements

III. parameters interacting with force or scope of negation

1) perfective aspect

2) periphrastic future

3) counterfactuals

4) interrogatives

5) emphatic negation 
In the subsequent sections I will examine each group of parameters in detail.

2. 1. 1. Clause-level Parameters Interacting with Referential Uniqueness of the Object

This group of parameters suggests that the occurrence of $A$ may be correlated with the NP's ability to refer to a unique individual. Proper nouns usually present unique individuals and entities selected out of a set of people or things; unique individuals and entities are those individuals and entities which the addressee is assumed to be able to single out of a set in terms of a distinct property or properties. Animate entities tend to be more frequently referred to and commented on in discourse, and consequently they tend to present referentially unique entities.

Neuter singular demonstratives это 'this', тo 'that', and प т० 'what, which' and other headless adjectives and pronominal adjectives tend to represent abstract notions, situations, or properties. These NP's, by definition, do not have a function of singling out a specific member out of a set, but rather have a definitional or what Donnellan calls an "attributive function" (Donnellan 1966:285-289) in most cases. For instance, in the following example the demonstrative 3 то does not single out a notion or situation or property as a member distinct from all the other members of a set: it merely refers to whatever type of appropriate manner of stroking the person's hair. 
(33) Ках поглаху [Махса по волосам]? ЭтогоG я не знала. (С. 357)

'How shall I stroke [Max's hair]? I did not know such a thing [lit. this] ${ }^{G}$.'

The demonstrative $\mathrm{TO}$ 'that' in the following example does not refer to a unique entity or activity, but rather any kind of entity or activity which fits the description presented by the subordinate clause.

(34) Татищев не отвергал тогоG, что радует глаз в ухо. (Kr. 151)

'Tatiščev did not reject anythingG that [lit. that which] pleased [lit. pleases] the eye and ear.'

Headless adjectives in the neuter singular are also definitional; for instance, the object ryqmee below does not refer to a unique entity, but anything that fits the description of being better.

(35) ЛучшегоG в хизни не едала! (ङ. 120)

'I have not eaten [anything] $G$ better [than this] in [my] life!'

My data thus suggest that the NP's which are likely to refer to unique entities trigger $A$, while the NP's which tend not to do so trigger G. It seems possible then to order object NP's linearly as shown below. Proper nouns are most likely to refer to unique individuals, while abstract nouns are least likely to do so; concrete nouns can be considered as constituting an intermediate category. 
The likelihood of the occurrence of $A$ increases towards the left, while that of $G$ increases towards the right. 5

\section{Eigure 1. A/G Selection and Object NP's}

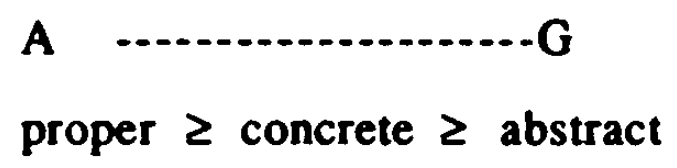

\section{1.2. Parameters Interacting with Semantic Properties of the}

\section{Verb}

My data indicate that there are two groups of verbs which are correlated with case selection; the verb $и м е т ь$ and verbs of perception and cognition favor $G$, while verbs with instrumental complements favor A. A close inspection of the semantic properties of the verbs identified thus far and other verbs reveals that the verbs in my corpus, as shown in Table 21 below, can be divided into three groups: existential, individuating, and neutral. Exhaustive lists of the "existential" and "individuating" verbs from my corpus other than иметs, verbs of perception and cognition, and verbs taking instrumental complements are given in Appendix 1 at the end of Part 1. 


\section{Table 21. Classification of Verbs}

I. existential verbs

1) the verb uм ть

2) verbs of perception and cognition (e.g., видеть/Увидеть 'to see', знать 'to know')

3) verbs of possession (e.g., дерхать 'to hold')

4) verbs with an effected object (e.g., Готовить/приготовить 'to prepare', писать/написать 'to write')

5) verbs of approval and tolerance (e.g., допускать/допустить 'to allow', видерхввать/видерхать 'to stand, tolerate')

6) verbs of provision and acquisition (e.g., доставлять/доставить 'to provide', получать/получнть 'to receive')

II. individuating verbs

1) verbs with instrumental complements (e.g., називать/назвать 'to name')

2) verbs implying change in one property of an entity as a result of the action (e.g., извивать/взвить 'to twist', оглушать/оглушить 'to deafen')

III. neutral verbs

(e.g., бросать/бросить 'to throw аway', читать/прочвтать 'to read')

According to my quantitative data, $G$ is more likely when the negative clause focuses on the absence of an entity or 
individual described by the object NP in a particular domain. The verb $M \in T$ is is strongly correlated with $G$. This verb, when negated, reports the absence of an entity in a certain domain. Иметь can thus be called an "existential" verb. Verbs of perception and cognition also correlate with $G$ and, like under negation, define a domain in which an entity is absent, in this instance the perceptual and cognitive domains. While under negation, is likely to report the absence of an entity in the given physical domain in general, verbs of perception and cognition report the absence of an entity within a more restricted domain; the entity may exist in the given physical domain, but it may not exist within the perceptual or cognitive domain.

The verb иметь and verbs of perception and cognition are not the only verbs which, under negation, report the absence of entities in one or another domain. Verbs of discovery (of the type ват hold') can be considered as verbs of possession. Under negation, the нанти-type verbs report the absence of an entity in a physical and/or perceptual domain as a consequence of failure to discover. The дерхать-type verbs are similar to the verb of possession u $\mathrm{M} \in \mathrm{T} b$ in that they, under negation, repoit the absence of an entity in a physical domain. Verbs with an effected object (e.g., $\Pi \mathrm{P} \not \square м \mathrm{I} \mathrm{b}$ 'to think up') are existential in that they, under negation, report the absence of an entity in a domain as a result of failure to produce. Verbs of approval and tolerance (e.g., Tepnets 
'to tolerate', признать 'to recognize'), under negation, report the absence of an entity sanctioned in a mental space. Verbs of provision and acquisition, under negation, report the shift in the domain in which some entity is absent. Verbs of possession, verbs of an effected object, verbs of approval and tolerance, and verbs of provision and acquisition can be viewed as constituting a group of "existential" verbs, together with verbs of perception and cognition and иметь; when negated, they all report the absence of an entity in some or another domain.

In contrast to existential verbs, verbs with instrumental complements, which correlate with $A$, have a totally different semantic property. This is clearly the case with the verbs of the predicative type (e.g., считать, 'to consider ( $x$ as y)'), whose instrumental complement is obligatory. The object and the complement governed by such verbs may be interpreted as an embedded subject and a predicate nominal ' $x$ is $y^{\prime}$; since the controller of a predicate nominal is said to be obligatorily referential (Nichols 1981:48), the object of such verbs is likely to be presented as referentially unique.

Constructions with an instrumental complement denoting means or instrument tend to focus on the manner or means by which the described action is carried out, rather than focusing on the presence or absence of the entity presented by the object NP. The negative clause below denies the manner in which the 
oratorical speeches were presented rather than focusing on their presence or absence.

(36) Ов не расџвечивал ораторские выступленияА пестрыми «"дветами храсноречия», не рисовался перед слушателями, во говорил выразительно и хиво. (Kr. 34)

'He did not adorn [his] oratorical speeches $A$ with bright "colors of eloquence", did not pose in front of the audience, but spoke expressively and lively.'

Verbs with instrumental complements, then, are likely to presuppose the existence of definite entities as their objects, and in this sense they can be labeled as "individuating" verbs.

Other verbs also share the property of individuation with the verbs with instrumental complements. These are verbs which imply change in one property of an entity as a result of the action. For instance, the verb разбивать/разбить 'to break' reports that the property of the object changes from 'being unimpaired' to 'broken'. These verbs presuppose the existence of a definite entity which is affected.

The verbs which belong neither to existential nor to individuating verbs may be called "neutral" verbs; 6 this means that their interpretations are variable in comparison with existential and individuating verbs. They include verbs of exchanging (e.g., переменять/переменить 'to alter') and verbs which do not denote actions changing the nature of the object (e.g., читать 'to read'). Verbs of transfer of the type уносить/унести 
'to carry away' also belong here; these verbs presuppose an individual that changes location, unlike verbs of provision and acquisition, which are primarily concerned with reporting the novel presence of an entity in a domain. More neutral verbs are given in Appendix 2.

These three groups of verbs described above can be represented in Figure 2. The likelihood of the occurrence of A increases towards the left, while that of $G$ increases towards the right.

Eigure 2. A/G Selection and Semantic Properties of the Vert

A $-\mathbf{G}$

individuating verbs $\geq$ neutral verbs $\geq$ existential verbs

\section{1. 3. Parameters Interacting with Force or Scope of Negation}

These parameters report whether or not the given situation can be contrasted with other possible situations.

Counterfactuals refer to various degrees of hypotheticality (Comrie 1986:88). They present a situation distinct from situations which are presupposed to be actual in terms of degree of probability. Interrogatives, especially rhetorical questions, can also present the given situation as distinct from other situations: the given situation to which the speaker does not subscribe and others which (s)he believes to be true. 
Perfective aspect in negative clauses may report that a potential, expected, or desired situation failed to hold by the time of reference (Forsyth 1970:104). The given temporal-aspectualmodal domain, then, may be presented as unexpected and exceptional, and contrasted with other comparable temporalaspectual-modal domains in which such an event would normally hold.

The periphrastic future can be used in a sense similar to собиратвся 'to plan [to do something]' or хотеть 'to want [to do something]' (Forsyth 1970:128-129). This construction, under negation, may therefore report the failure to carry out a hypothetical or expected or intended action; in other words, it may contrast the given hypothetical world in which the situation does not hold as distinct from other comparable hypothetical domains in which such a situation might hold.

Counterfactuals, interrogatives, perfective aspect, and periphrastic future can be grouped together as 'temporalaspectual-modal operators'; the force of negation in these constructions is attenuated because they can imply other temporal-aspectual-modal domains in which the corresponding affirmative situation holds.

As for imperfective present and past and emphatic negation, parameters which correlate with G, they share a different property. 
Emphatic negation negates both the verb and the object, and it can be considered as complete negation which focuses on the general absence of the entire situation. Imperfective aspect in the past and present tenses follows suit to a certain extent; it can deny the general presence of the described situation over a period of time (or report a "continuous state of nonperformance" (Chaput 1985:226)).

Thus, this group of parameters in relation to the likelihood of $A$ and $G$ can be represented in the following fashion.

\section{Eigure 3. A/G Selection and the Force of Negation}

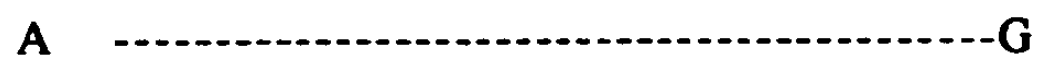

temp.-asp.-modal oper. $\geq$ impf. pst. \& prs. $\geq$ emph. neg.

In the subsequent sections I will present the percentages of $A$ in various combinations of the parameters located in Figures 1 to 3 .

\section{2. Interaction among the Three Types of Clause-level}

\section{Parameters}

2. 2. 1. Combinations of Clause-level Parameters and Case Selection

Various combinations of the clause-level parameters and the frequency of $A$ are presented in Tables 22-24 below. Here "\#" refers to the raw number of examples and "A\%" to the percentage 
of A. Concrete nouns are defined as those nouns denoting tangible entities and individuals; all other common nouns, together with это, что, то, многое, and headless neuter singular adjectives, are treated as abstract nouns. Discussion follows the tables.

Table 22. Emphatic Negation and Other Clause-level Parameters

abstract concrete proper

$A \# / G \#(A \%) \quad A \# / G \#(A \%) \quad A \# / G \#(A \%)$

$\begin{array}{lllll}\text { exist. verbs } 0 / 33(0) & 0 / 26(0) & 1 / 3(25) \\ \text { neutral verbs } 0 / 4(0) & 1 / 16 \quad(5.9) & 1 / 0 \quad(100) \\ \text { indiv. verbs } & - & - & & -\end{array}$

Table 23. Imperfective Past \& Present and Other Clause-level Parameters

\begin{tabular}{llll} 
& abstract & concrete & proper \\
& $A \# / G \#(A \%)$ & $A \# / G \#(A \%)$ & $A \# / G \#(A \%)$ \\
\hline exist. verbs & $5 / 179(2.7)$ & $14 / 109(11.4)$ & $13 / 3(81.3)$ \\
neutral verbs & $11 / 77(12.5)$ & $41 / 50(45.1)$ & $12 / 0(100)$ \\
indiv. verbs & $6 / 9(40.0)$ & $9 / 9(50.0)$ & $6 / 0(100)$
\end{tabular}

Table 24. Temporal-aspectual-modal Operators (Perfective Aspect. Periphrastic Future. Counterfactuals. Interrogatives) and Other Clause-level Parameters

\begin{tabular}{llll} 
& \multicolumn{1}{l}{ abstract } & concrete & proper \\
& $\mathrm{A} \# / \mathrm{G} \#(\mathrm{~A} \%)$ & $\mathrm{A} \# / \mathrm{G} \#(\mathrm{~A} \%)$ & $\mathrm{A} \# / \mathrm{G}$ (A\&) \\
\hline exist. verbs & $13 / 82(13.7)$ & $23 / 42(35.4)$ & $12 / 0(100)$ \\
neutral verbs & $22 / 48(31.4)$ & $58 / 32(64.4)$ & $12 / 0(100)$ \\
indiv. verbs & $12 / 9(57.1)$ & $15 / 4(78.9)$ & $5 / 0(100)$
\end{tabular}


First, let us examine Table 22 in comparison with Tables 23 and 24. It is clear that $G$ is almost obligatory (except for the cells with proper object NP's) under emphatic negation, regardless of the degree of referential uniqueness of the object or the semantics of the verb.

In both Tables 23 and 24, certain combinations of object NP's and verbs almost automatically trigger one case: abstract NP's governed by existential verbs trigger $G$ and proper NP's governed by non-existential verbs trigger $A$. The percentage of $A$ among abstract NP's governed by existential verbs is $2.7 \%$ in Table 23 and $13.7 \%$ in Table 24; these frequencies of $A$ are very low. The percentage of A among proper NP's governed by neutral and individuating verbs is $100 \%$ in both Table 23 and Table 24 .

In other combinations of object NPs and verbs, the presence of temporal-aspectual-modal operators triggers A more frequently than imperfective present and past. For instance, when common object NP's are governed by neutral verbs, the percentages of $A$ in Table 24 are consistently higher than those in Table 23: the percentage of $A$ among abstract object NP's is $31.4 \%$ in Table 24, while it is $12.5 \%$ in Table 23; the percentage of A among concrete object NP's is $64.4 \%$ in Table 24 , while it is $45.1 \%$ in Table 23. The same relation also holds in examples with concrete object NP's governed by existential verbs; the percentage of $A$ is $35.4 \%$ in Table 24 , while it is $11.4 \%$ in Table 23. 
Within Tables 23 and 24 , it is clear that the percentage of $A$ increases in accordance with the likelihood of the object NP's to refer to specific individuals. Thus, in Table 24 , the percentage of $A$ is the highest among proper NP's and the lowest among abstract nouns; for example, the frequency of $\mathrm{A}$ is $100 \%$ in proper object NP's governed by neutral verbs, 64.4\% among concrete object NP's, and 31.4\% among abstract object NP's. Similarly, in Table 23 the frequency of $A$ is $100 \%$ in proper object NP's governed by neutral verbs, $45.1 \%$ among concrete object NP's, and $12.5 \%$ among abstract object NP's.

The effect of semantic properties of the verb, like referential uniqueness of the object, can be seen in Tables 23 and 24. In Table 23, the frequency of $A$ is the lowest in examples with concrete object NP's governed by existential verbs $(11.4 \%)$; it is somewhat higher in examples with neutral verbs (45.1\%); and it is the highest in examples with individuating verbs (50.0\%). The same can be said about Table 24 . The combination of concrete object NP governed by existential verbs has the lowest frequency of A (35.4\%); the combination of concrete object NP's governed by neutral verbs has a somewhat higher frequency (64.4\%); and the combination of concrete object NP's governed by individuating verbs has the highest frequency of $\mathrm{A}$ (78.9\%).

In summary, except for the environment of emphatic negation, which overrides almost all the other parameters, referential uniqueness of the object, semantic properties of the 
verb, and scope or force of negation correlate with case selection to varying degrees.

Let us now convert Tables $22-24$ into tables which represent which case is selected and to what extent case selection is automatic (Tables 25-27).

\section{2. 2. Degrees of Automaticity in Case Selection}

Tables 22 to 24 can be converted into Tables 25 to 27 below with the following notations:

G: G predominant (85\% or above)

G>A: $G$ prevalent (less than $75 \%$ but always larger than A)

$G=A: A$ and $G$ equivalent

G<A: A prevalent (less than $75 \%$ but always larger than $G$ )

$\mathbf{G}<$ A: A very much outweighs $G(75 \%-85 \%)$

A: A predominant (85\% or above)

?: absolute number of cell extremely small; given percentage not very reliable

-: no examples

Table 25. Degrees of Automaticity in Case Selection in the Examples with Emphatic Negation abstract

exist. verbs $\mathbb{G}$

neut. verbs $\mathbb{G}$

indiv. verbs concrete

$\mathbb{G}$

$\mathbb{G}$
$\mathbb{A}$ ?

proper

G>A? 
Table 26. Degrees of Antomaticity in Case Selection in the

Examples in the Imperfective Past \& Present

abstract concrete

proper

$\begin{array}{llll}\text { exist. verbs } \mathbb{G} \quad \mathbb{G} & \text { G }<<A\end{array}$

neut. verbs $\mathbb{G} \quad G A \quad \mathbb{A}$

indiv. verbs $\quad G A A \quad G=A \quad A$

Table 27. Degrees of Automaticity in Case Selection in the

Examples with Temporal-aspectual-modal Operators

abstract

exist. verbs $\mathbb{G}$

neut. verbs

GA

indiv. verbs G<A concrete

GA

G<A

G<eA proper

A

A

A

As noted above, emphatic negation yields $G$ almost automatically; properties of the object NP and the verb are almost irrelevant, except when emphatic negation clashes with the parameter of proper NP (Table 25).

When one looks at Table 26, it is clear that, in the imperfective past and present, case selection in many of the cells is determined on the basis of the verb and the object. Existential verbs trigger $G$ in common object NP's; neutral verbs, when governing abstract NP's, trigger G; and proper NP's trigger A almost automatically when governed by neutral and individuating 
verbs. In the other remaining cells, case selection is less automatic. The combination of neutral verbs and concrete object NP's and the combination of individuating verbs and abstract object NP's favor $G$, but the frequencies of $A$ cannot be considered marginal. When individuating verbs govern concrete object NP's, both $A$ and $G$ are equally possible.

In Table 27 the presence of proper object NP's triggers A, while the combination of existential verbs and abstract object NP's triggers $G$ nearly automatically. In the remaining cells $A$ or $G$ is favored, but case selection cannot be considered automatic. The gray area not showing near-automatic case selection is thus larger in this table than that in Table 26. In Table 27 four cells show near-automatic case selection, while in Table 26 five cells do so.

The cells showing near-automatic case selection are the environments in which case is primarily determined by the clause-level parameters. I will call these environments "strong environments", as opposed to "weak environments", those in which case selection is less automatic. The difference among environments is represented graphically below (Figures 4 to 6 ).

The dark solid zones connected with $A$ or $G$ indicate strong environments. The patterned zones, both dark and light, represent weak environments. The darkness of the dotted zones is proportional to the degree to which case selection is likely to be determined on the basis of clause-level parameters. The presence of two parallel dotted zones, which extend both from $A$ and $G$, 
indicates that the motivation for case selection in those environments is unclear; these are either environments for which there is not sufficient data to indicate the degree of automaticity in case selection, or those environments in which $A$ and $G$ seem to occur equally. It seems that there is little contextual influence on case selection in the strong environments, while context interacts with case selection in weak environments. I will test this hypothesis on individual examples in the subsequent sections. I will also attempt to document some general properties of $A$ - and G-clauses in this process. 
Eigure 4. Strong and Weak Environments with Emphatic Negation \begin{tabular}{|l|l|l|l|l|}
\hline $\begin{array}{l}\text { prop }+ \\
\text { neut./ind. }\end{array}$ & $\begin{array}{l}\text { prop }+ \\
\text { ex. }\end{array}$ & $\begin{array}{l}\text { con. }+ \\
\text { neut. }\end{array}$ & $\begin{array}{l}\text { con. }+ \\
\text { ex. } \\
\text { ebst. }+ \\
\text { neut. }\end{array}$ & $\begin{array}{l}\text { ebst. }+ \\
\text { A }\end{array}$
\end{tabular}

Eigure 5. Strong and Weak Environments in the Imperfective Past and Present

\begin{tabular}{|c|c|c|c|c|c|c|}
\hline $\begin{array}{l}\text { prop + } \\
\text { neut./ind. }\end{array}$ & $\begin{array}{l}\text { prop + } \\
\text { ex. }\end{array}$ & $\begin{array}{l}\text { con. }+ \\
\text { ind. }\end{array}$ & $\begin{array}{l}\text { con. + } \\
\text { neut. }\end{array}$ & $\begin{array}{l}\text { abst. + } \\
\text { ind. }\end{array}$ & $\begin{array}{l}\text { con. + } \\
\text { ex. } \\
\text { ebst. + }\end{array}$ & $\begin{array}{l}\text { obst. + } \\
\text { ex. }\end{array}$ \\
\hline & & $\because \because \therefore: \therefore: \therefore: \therefore: 8$ & & & neut. & \\
\hline
\end{tabular}

Eigure 6. Strong and Weak Environments with Temporalaspectual-modal Operators

\begin{tabular}{|c|c|c|c|c|c|c|}
\hline $\begin{array}{l}\text { prop + } \\
\text { neut./ind. }\end{array}$ & $\begin{array}{l}\text { prop + } \\
\text { ex. }\end{array}$ & $\begin{array}{l}\text { con. }+ \\
\text { ind. }\end{array}$ & $\begin{array}{l}\text { con. + } \\
\text { nevt. }\end{array}$ & $\begin{array}{l}\text { abst. + } \\
\text { ind. }\end{array}$ & \multirow{2}{*}{$\begin{array}{l}\text { con. + } \\
\text { ex. } \\
\text { obst. + } \\
\text { neut. }\end{array}$} & \multirow[t]{2}{*}{$\begin{array}{l}\text { obst. + } \\
\text { ex. }\end{array}$} \\
\hline & & & $\because \because: \because: \because$ & $\because \because \therefore: \because: \because: \because 8$ & & \\
\hline
\end{tabular}




\section{Chapter 3. Strone and Weak Environments for Case Selection}

The following are the environments which were considered "strong".7 They are divided into two groups: one triggering $G$ and the other triggering $A$.

\section{Table 28. Strong Environments for Case Selection}

I. strong environments triggering $G$

1) common object NP's cooccurring with emphatic negation

2) abstract object NP's governed by existential verbs

3) imperfective past and present

3a) concrete object NP's governed by existential verbs

3b) abstract object NP's governed by neutral verbs

II. strong environments triggering $A$

1) proper NP's governed by neutral and individuating verbs in the imperfective present and past

2) proper NP's cooccurring with temporal-aspectual-modal operators

In the analyses of individual examples below, I will argue that all the strong environments triggering $G$ consistently yield one interpretation of the negative clause, while all the strong environments triggering $A$ consistently yield another interpretation.

\section{1. Strong Environments Triggering G}

First let us examine the strong environments triggering G. All 
the environments listed in Table 28 suggest that $G$ is motivated when the given negative clause invokes a certain type or set, but does not distinguish any particular member from others within it. Discussion of each of the strong environments triggering $G$ follows.

\section{1. 1. Emphatic Negation and Common NP's}

The examples with emphatic negation and common object NP's are subdivided into two groups: those with abstract object NP's and those with concrete object NP's. The former combination reports the absence of any portion or aspect which constitutes the abstract notion described by the object NP. The following are some examples with abstract object NP's.

(37) Маша [...] очень сердплась на Артемьева за то, что тот не проявлял нихахого вниманияG $\mathrm{K}$ этон, очевидно, очень хорошей, но совершенно ве нравившеися ему хендиние. (S. 26)

'Maša [...] was very upset by Artem'ev because he did not show any [bit of] attentionG to this, obviously very attractive, but not-at-all-liked-by-him woman.'

(38) Нихахого различияG мехду нами нихто из преподавателен нихогда не делал. (Kr. 10)

'Not one of the teachers ever made any distinction ${ }^{6}$ among us.'

In the first example above, the emphasis is on the absence of any bit of attention that Artem'ev showed towards the woman, 
and in the second example it is on the absence of any hint of distinction made by any of the teachers. In each example the focus is on the absence of any behavior which can be characterized by the given abstract notion. This can be seen as emphasis on the absence of any single member which constitutes a set.

The clauses with $\mathrm{Hи...,} \mathrm{ви...'neither...,} \mathrm{nor...'} \mathrm{are} \mathrm{similar} \mathrm{to} \mathrm{those}$ presented above. These clauses report the absence of any of entities which fit the description of the object NP's.

(39) Я не помню ни шумного успехаG, ни просто успехаG «Горького џвета» (Š. 130)

'I remember neither a roaring success $G$, nor simply a success $\mathbf{G}$ of "The Bitter Color"'.

(40) Дахе в молодости я нихогда не овудала ни одиночества, ни недостатхаG жизненных перехивания. (Ja. 48)

'Even in youth I felt neither loneliness ${ }^{G}$, nor lack $G$ of reallife experiences.'

The first example reports that there was no manifestation of any of the two abstract notions -- a roaring success or a simply success -- in the speaker's memory. The sezond example reports that there was no feeling which can be characterized by any of the two abstract notions, loneliness or lack of real-life experiences. 
When concrete NP's occur with emphatic negation, the negative clause emphasizes the absence of any single member of the type of entity described by the object NP.

(41) $\mathrm{K}$ сохалению, нихахого письмаG от Вас я не получил. (S. 152)

'Unfortunately, I have not received any letter $G$ from you.'

(42) $[\ldots]$ но [Он] ве вбил в стену ни одного ГвоздяG, $[\ldots]$ (Rb. 14)

'[...] but [he] did not hammer in a single nailG into the wall, [....]

The first example reports the absence of any single letter received by the speaker, and the second example the absence of any single nail hammered into the wall.

The following example, with definite objects which presuppose a specific grave and a specific funeral, reports that no relevant property about any of the listed entities exists in the speaker's memory.

(43) Я прошла со всеми на хладбище, но не помню ни могильG, ни похоронG. (C. 264)

'I went along with everyone to the cemetery, but I remember neither the graveG, nor the funeralG.'

Similar interpretations are found in examples with abstract object NP's governed by existential verbs. 


\section{1. 2. Abstract Object NP's Governed by Existential Verbs}

Abstract object NP's governed by existential verbs yield an interpretation similar to the ones which have been observed so far. Consider the following examples in the imperfective aspect:

(44) Mи не знали расхлябанностиG, разгильдяистваG, с ранних лет были приучены $\mathrm{x}$ вехливости, увахению $\mathrm{x}$ старшим. (Kr. 11)

'We did not know lack of discipline ${ }^{G}$, sloppiness $G$, we were trained from early years to be polite, to respect our elders.'

(45) Ее советы нихогда не носили харахтераG поученин. (Ја. 79)

'Her pieces of advice never carried the characterG of sermons.'

(46) Мастера высмеяли Броневсхого за то, что он не звает терминологии. [...] В общем, вичего хорошего ему эта интрига не принесла. Дальнеишен его судьби не знаю. (Rb. 191)

'Master craftsmen ridiculed Bronevskij for the fact that he did not know the terminology. [...] In general, this intrigue did not bring anything good to him. I do not know his further fate ${ }^{G}$.'

In example (44) the object NP's deny the presence of any manifestation of lack of discipline or sloppiness in the work of the individual; example (45) denies the existence of any hint of sermon in the individual's advice. Example (46) denies the 
presence of any of the further developments in Bronevskij's life (which can be characterized as 'his further fate') in the speaker's knowledge.

Negative clauses with object NP's governed by existential verbs cooccurring with temporal-aspectual-modal operators report a set of entities with no distinct properties. The following example has the verb иметъ 'to possess' in a counterfactual negative clause.

(47) Не стала бы говорить об этом эпизоде, өсли би он ве нмел глубокого смыслаG: лучшие артисти Малого төатра не признавали искусства, оторванного от хизвеннон правды, только человек интересовал их. (Ја. 66)

'I would not have started talking about this episode, if it did not have any [bit of] profound meaning $G$ : the best actors of Maly Theater did not acknowledge art ripped away from the vital truth, only a human being interested them.'

The speaker in the negative clause above reports the actual presence of some fact which can be characterized by "deep significance". Thus, the negative clause does not present one particular entity as being distinct from others in a set, but merely reports the existence of some entity which fits the property presented by the object NP.

Here is an example with a perfective verb.

(48) Панченко, хотя и потерял много крови, еще не почувствовал слабостиG. (S. 81) 
'Pančenko, even though he had lost much blood, still had not started feeling any weakness $G$.'

The negative clause above in the perfective aspect denies the existence of any sensation which could be characterized as weakness by the time of reference.

Examples with concrete object NP's governed by existential verbs in the imperfective past and present yield similar interpretations.

3. 1. 3. Concrete Object NP's Governed by Existential Verbs in the Imperfective Present and Past

In the aforementioned environment, negative clauses invoke a set of entities, without distinguishing any particular member out of it, in a certain domain. Here are some examples.

(49) Петровскин в то время не имел семьй. (S. 42)

'Petrovskij at that time did not have a familyG.'

(50) я от вас подархаG не получала. (5. 96)

'I did not receive any gift $G$ from you.'

(51) $[\ldots]$ на нен же пуговињы болтаются, она в хизни иголхй в рухах не держала... (Rb. 179)

'[...] there are buttons hanging loosely on her, she has not held a [single] needle $G$ in her hands in her life...'

In the first example above, the object NP is nonreferential; the negative clause yields an interpretation that there was no entity of the type described by the object NP in the given domain. In the second example above, the speaker states the absence of any gift 
received by her. In the third example, the speaker denies the presence of any single needle held in the woman's hands in her life. Each of these three examples denies any entity which fits the description in the given domain; a type or set of entities is invoked, but none of the members is presented as distinct.

The following is an example with a definite object NP.

(52) Своего ответаG не помню -- ов потонул в горе... (C. 78)

'I do not remember my reply -- it has sunk into sorrow.'

In example (52) the speaker knows that she gave an answer, but no property or information about it was available in her memory. Instead of invoking a set of entities, the clause here invokes a set of properties, without presenting any of its members as distinct.

3. 1.4. Abstract Object NP's Governed by Neutral Verbs in the Imperfective Present and Past

Let us examine some examples with abstract object NP's governed by neutral verbs in the imperfective aspect.

(53) Мама не любила хозянстваG -- тах нам после говорили ○ нея, и хоть я помню, хах она метила (...) белье, и дахе вышивала порои, крестиком, и заказывала обеды и ужины, и поливала уветы; (...) (С. 24)

'Mama did not like housekeeping .- so they told us afterwards about her, although I remember how she sewed [letters] $[. .$.$] on the linen, and even embroidered every now$ 
and then in cross-stitch, and ordered lunches and dinners, and watered flowers; [...]'

(54) Ахтерских удач в спектакле было много. Всех и не перечтешь. С годами спектакль «Порт-Артур» не терял свежестия, а ках бы ухреплялся корнями и рос. ('́. 322) 'There were many successes by actors in the play. One cannot enumerate all of them. Over the years the play "Port Arthur" did not lose [its] freshness $G$, it, as it were, put down roots and grew.'

The imperfective aspect in the first example above suggests that the speaker's mother did not like any activity which can be labeled as housekeeping.

The second example reports that, in spite of many years of being performed, the play never lost its freshness. In other words, the freshness could have been lost at any time during the given period, but this situation never took place at any point in the temporal-aspectual domain; the negative clause focuses on the total absence of any temporal-aspectual points at which the situation held.

The observations here are consistent with those made earlier. The parameters automatically triggering $G$ thus seem to invoke a certain set of members, none of which is viewed as distinct. Let us now turn to strong environments triggering $A$. 


\section{2. Strong Environments Triggering A}

The strong environments triggering $A$ yield an interpretation different from those triggering $G$.

\section{2. 1. Proper NP's Governed by Neutral and Individuating Verbs}

\section{in the Imperfective Present and Past}

Let us look at the following example.

(55) Хонечно, пресса ве приветствует «Проститутху»А. (Цૅ.

'Of course, the press does not welcome "The Prostitute"A'. Here the play is a unique entity, with its distinct properties already assumed, within a set of plays. This interpretation is further supported by конечво 'of course', to acknowledge the negative properties of that particular play, that is, the properties which present the play as a distinct type from other types of plays which might not be evaluated so harshly.

The example below also yields a similar interpretation.

(56) Глаза у Синцова стали сердитмми. Он не любил НадюА и сенчас подумал о неи. (S. 27)

'Sincov's eyes became angry. He did not like $\operatorname{Nadja}^{A}$ and had started thinking about her now.'

In (56) the proper NP refers to a unique individual. The properties distinguishing her from other individuals are already assumed to be known. The neutral verb 'to like', does not interfere with this interpretation since it does not strongly report the presence or absence of the entity presented by the object NP. The 
combination of the verb and the object NP thus seems to present the individual as a distinct member of a set of individuals.

The following example involves a proper NP governed by an individuating verb in the imperfective.

(57) И знаете, в нем [ИГоре] было известное блаГородство, не обижал олюА, та уже ходила в третин класс, тихая, застенчивая девочка, ен пришлось преодолеть в доме отчужденность, даже враждебность, [...] (Rb. 193)

'And, you know, there was a certain nobility in him [Igor'], he did not insult $\operatorname{Olja}^{A}$, she was already a third-grader, a quiet, shy girl, she had to overcome alienation at home, even hostility, [...]'

Olja is a unique individual whose properties which differentiate her from other individuals are assumed to be known. The individuating verb 'to insult', which implies change in the property of the object, further reinforces referentially unique interpretation of the object NP. Thus, the combination of the verb and the object NP seems to present the given individual as a distinct member of a set of individuals.

In the next section we will look at examples occurring with temporal-aspectual-modal operators. 


\section{2. 2. Proper NP's Cooccurring with Temoornl-aspectual-modal}

\section{Operators}

When proper NP's cooccur with temporal-aspectual-modal operators, focus on a particular member of a certain set is almost automatic.

The following example has a proper object NP governed by an existential verb 'to see'.

(58) Rах! Марию ПаперА не видела? Вон хе она -- разве не видишь меч? (C. 378)

'How [could you not]! You didn't see Marija PaperA?' There she is -- don't you see the sword?'

Marija Paper is a unique individual; she is therefore viewed as a unique individual with various properties which differentiate her from other people. This interpretation is reinforced by the fact that the object NP is in an interrogative clause. The speaker questions the possibility that the addressee has not seen Marija Paper; this can be interpreted as implying that her distinct properties are so obvious that the addressee could not have failed to identify her. In other words, the proper NP, together with the interrogative, presents the individual as unique, whose many properties differentiating her from other individuals should be obvious to the addressee.

Similar interpretations are possible with examples with proper object NP's governed by neutral verbs, as shown in the example below. 
(59) [...] домработница не онала, пускать нас или нет, провела не в хомнату, а $\mathrm{x}$ с е $б$ е, на хухню, дахе стахана чая не предложила, опять же от растерянности, не позвала ОлечкуА х бабушхе и дяде, [...] (Rb. 123)

'[...] the maid did not know whether to let us in or not, she led us not into the sitting room, but to her place, into the kitchen, she did not even offer a glass of tea, and, again, out of dismay she did not summon OlečkaA to [see] her grandmother and uncle, [...]'

Here Olečka is a unique individual whose properties distinguishing her from other individuals are already assumed to be known. The verb in the perfective aspect lines up with this presentation of the individual. The perfective aspect, together with this property of the object NP, suggests that the action was not carried out by the maid on this occasion, although such action is expected to be carried out by the time of reference; this suggests a special relationship between the child on one hand and the speaker and his mother on the other hand (that is, she is not merely a child, but a child who has special relationship to the speaker and the speaker's mother).

The following example involves a proper NP governed by an individuating verb in the perfective and yields an interpretation similar to the one which we have just observed.

(60) Анну Андреевну я не провалила. Но и особых лавров она мне не принесла. (ऽ. 312) 
- I did not make a complete mess of Anna AndreevnaA. But the role did not bring me special laurels either.'

The object NP refers to a unique role in a play among a set of roles; this alone makes the entity distinct from other possible members of the set. In addition to the inherent property of the object, however, the verb in the perfective aspect 'to make a complete mess of suggests that the speaker could have played the role better; some properties were expressed well, but there were many other properties of the role which should have been better expressed by the speaker. Thus, the verb in the perfective aspect and the property of the object NP present the role as having various properties which make it a distinct member of a set of roles.

The strong environments triggering $A$ thus almost automatically present object referents as unique individuals. In contrast to clauses with $G$, then, negative clauses with $A$ can be said to distinguish one member out of a set of individuals.

We shall now turn to examples occurring in weak environments and examine what motivates case selection there. The questions to be asked are whether similar semantic operations of the types observed here take place even in the examples in weak environments, and, if this is the case, what is motivating such semantic operations. 


\section{3. Weak Environments Favoring $G$}

The following is the list of weak environments favoring G:

\section{Table 29. Weak Environments Favoring G}

I. object NP's cooccurring with imperfective past and present

1) concrete object NP's governed by neutral verbs

2) abstract object NP's governed by individuating verbs

II. object NP's cooccurring with temporal-aspectual-modal operators

1) concrete object NP's governed by existential verbs

2) abstract object NP's governed by neutral verbs

I will analyze and compare near-minimal pairs -- examples with the expected $G$ and examples with the somewhat unexpected A occurring in these environments. ${ }^{8}$

3. 3. 1. Concrete Objects Governed by Neutral Verbs in the Imperfective Present and Past

The following two examples involve the verb пропускать 'to miss, skip' with спектакли 'performances, shows' as the object NP.

(61) Обычно Николай не пропускал сиектахлен с моим участием, но в этот вечер почему-то остался дома. (క. 101) 
'Usually Nikolaj did not miss performances ${ }^{G}$ with me in them, but on that evening, for some reason, [he] stayed at home.'

(62) Оленька не пропускает спектаклиА с участием Нихолая Мариусовича, смотрит, учится. (ङ. 143)

'Olen'ka does not skip the peformances $A$ with Nikolaj Mariusovič in them, watches them, studies them.'

The object NP in example (61) presents a set of performances with no particular distinct member. The context reinforces this meaning. The negative clause reports that he did not miss any of his wife's performances in general. 9

The negative clause in (62) also has the plural of cпехтакль 'performance, show'. Here, however, the interpretation of the object NP is modified by the context. The text following the negative clause presents motivations for Olen'ka's not skipping Nikolaj Mariusovič's performances; they were worth studying. This entails the following interpretation of the negative clause: '(while she might have missed other performances which were not worth studying,) she did not miss Nikolaj Mariusovič's performances because they were worth studying'. Thus, the group of entities 'N. M.'s performances' is presented as distinct from other possible performances in this context.

Let us look at another near-minimal pair involving the verb отхривать 'to open'.

(63) А мамаша профессора, [...] вовсе стала, что называется, 
весело В АО в О и носила на шее массивную золотую मепь с золотым медальоном. А что было в медальоне, нихто не знает, медальона она никогда не отхрывала, может там был чеи-то портрет, и хто знает, возмохно, портрет подрядчиха!.. (Rb. 32)

'But the professor's mother [...] completely became what is called a merry widow and was wearing a massive gold chain with a gold medallion on her neck. But what was in the medallion, nobody knows, she never opened the medallionG, it's possible that somebody's portrait was there, and who knows, possibly the [railroad] contractor's portrait!..'

(64) Пришла беда. В ярости стида и негодования, повмав Володю на воровстве у кого-то ив пансионеров, Алехсандр ЕГорович творит нещадную расправу над скном, -- даже Лёре он не откривает аверьА, в хоторую она стучится. (С. 112)

'There came misfortune. In a frenzy of shame and indignation, having caught Volodja stealing from one of the guests, Aleksandr Egorovič creates a merciless punishment for his son, -- even for Laura does he not open the door $A$ on which she is knocking.'

In (63), the object NP is definite and referential. The speaker of this text is commenting on the fact that, for all those years (while she was wearing the medallion), she could have shown what was inside of her medallion, but she did not show it on any of the 
possible occasions during this period of time. The focus is thus on the absence of any member of a set of temporal-aspectual points in which the given action could have occurred.

In (64) the object NP is also definite and referential. This example is slightly different by virtue of the presence of an oblique argument 'even for Laura', which suggests that this situation is unusual. The context is also different from the previous example in that there is reference to Aleksandr Egorovič's unusual degree of anger against his son. The reading of the negative clause should then be as follows: 'If Laura knocks on the door, under normal conditions he would definitely open the door, but this particular occasion was quite unusual in that he did not do this even for Laura'. Thus, the negative clause presents the given occasion as a distinct member of a set of comparable occasions.

Again, the examples suggest that case selection in this group of examples is determined not purely by the presence or absence of clause-level parameters, but also by the way in which context characterizes the nature of the negative situation.

Let us move on to another group of examples.

\section{3. 2. Abstract Object NP's Governed by Individuating Verbs}

The following set of examples involves the verb прермвать to interrupt'. The object NP's тPYA 'labor' and nотоX potentially have concrete submeanings of 'a piece of tangible work' (such as an article or book) and 'a stream of water' respectively, but in the 
following instances, they both refer to activities ('work or effort for building the museum' and 'flow of despair that God does not exist').

(65) С хаким мухеством вынес он свое «увольнение от долхности»! Ках, подавив в себе чувства печали и негодования, -- он дахе на самое коротхое время не прерквал своего трудаG по созданию нового Музея! Полученнын удар не сделал его ни разочарованним в слухении просвешению, ни озлобленным. (С. 342-343) 'With what courage did he endure his "dismissal from his job"! How -- having repressed the feelings of sorrow and indignation in himself -- did he not interrupt his work $G$ in creating the new Museum even for a short period of time! The blow received made him neither disenchanted in the service of enlightenment nor embittered.'

(66) И вот ма сиАим вавоем в глубокон тихон редахдионнон комнате; он отбросил рукописи и книги, без конда говорим... Он слушает мон рассказ о моен будушен книге, в ее перепишу, пришлю, и он не прерывает потохА моего утверждающегося отчаяния, что нет Бога, мое полное отвержениеА веры. Все знакомо өму. Понятно. И хорни видны. Он не ополчается на мон протест против его веры, не спорит. Он берет мон руки и смотрит в глаза, [...] (С. 551) 
'So now we are sitting together in a deep quiet editorial office; he had thrown aside the manuscripts and books, we talk endlessly... He listens to my story about my future book, I will rewrite it, [and] send it in, and he does not interrupt the flow of my consistent despair, that God does not exist, my complete rejection of faithA. Everything is familiar to him. Understandable. Even the roots [of the problem] are clear. He does not take up arms against my protest against his faith, he does not argue. He takes my hands and looks into my eyes, [...]'

In (65) the prepositional phrase дахе ва самое сороткое врема 'even for the shortest time' indicates that the speaker emphasizes the absence of any single stretch of time in which the speaker's father gave up on his project during the given period of time. The example thus reports a certain duration of time and the absence of any portion of it in which the situation held.

(66) is part of a text about the speaker's meeting with her friend. The text surrounding the negative clause suggests that the speaker's main focus is on how special he was and how special this meeting was. The negative clause therefore can be interpreted as evaluating the given event as something extraordinary and different from similar experiences she had had: 'In similar instances people interrupt such a flow of my despair that God does not exist, but this occasion was special in that this sort of event did not hold.' 
The examples above indicate once again that context contributes considerably to the generation of the interpretations of A- and G-clauses. $G$ is likely when the both clause-level parameters and context refer to a set of members with no special characteristics, while $A$ is likely when context interferes with clause-level parameters and distinguishes a specific member out of a set.

In the following two sections we will look at examples with temporal-aspectual-modal operators.

\section{3. 3. Concrete Object NP's Governed by Existential Verbs with}

The following set of examples involves the verb натти 'to find'.

(67) А у ребят бнло договорено: если попадутся, то ни в коем случае не вцдавать подземного хода, умереть, но не вцдавать: өсли эсэсовиу обнарухат погреба д то, что в погребах, то расстреляют всех хителен дома. И, хогда мальчихи увидели немнев, они стали уходить не $x$ Подвемному ходу, [..] -- ОНи Уходили в дальнюю противополохную сторону, (..). Эсэсовцы шли за ними, стреляли и настигли их, [...] Илью пристрелили внизу, а Саша тах на заборе, мертвыи, и повис. [...) Немы нашли и бочки с хонфетно начинкои, но подземного ходаG не вашли. (Rb. 264)

'But the boys had an agreement: if they are caught, under no circumstance should they give away the underground path, 
die, but not give it away: if the SS men find the cellars, and what is in the cellars, then they will shoot all the inhabitants of the house. So when the boys saw the Germans, they started going not towards the underground path, [...] -- they went in the opposite direction, [...]. The SS men went after them, shooting, and caught up with them, [...] they killed Il'ja from below, and $\mathrm{Saša}$ also on the fence, he hung [from the fence] dead. The Germans even found the barrels with candy filling, but they did not find the underground path $G$.' (68) -- Секретер точво для этого угла был создав!

-- Да, веди сами идут в руки, когда их ищешь. (...l

-- A mарманку А до сих пор не нашла (C. 538)

"The writing desk has been made just for this corner!" "Yes, things come into your hands by themselves, when you look for them."

"But I still haven't found a street organ A up until now."

The text preceding the negative clause in (67) makes reference to an agreement which indicates that it was extremely important for the people in the ghetto to keep the Germans from finding the underground passage. The text here therefore can be understood as focusing on the fact that the path remained unknown to the Germans. In this context, then, the negative clause can be interpreted as emphasizing the definitive failure of the type of event described (the Germans' finding the path), which kept the passage unknown to the Germans. 
In (68) the text preceding the negative clause refers to an assumption shared by speaker and by the addressee that one always finds the right things for one's apartment if one looks for them. Then, the object NP in the negative clause can be interpreted as referring to a specific type of street organ rather than any street organ -. the kind that is appropriate for the speaker's home. Thus, the negative clause presents a member as distinct from other members of the same set at two levels. At the level of the object, the entity is presented as a distinct type of member out of a set in terms of a specific property. At the level of temporal-aspectual-modal domain, the given temporal domain (up until the temporal point referred to as do cux nop 'up until now') is presented as exceptional in contrast with other temporal-modal domains. This can be paraphrased as follows: 'while comparable events would normally take place in similar circumstances, it is unusual that up to this point the given event has not taken place.'

In the following two examples the object NP's are both referential and definite, and are governed by the verb зиать 'to know'.

(69) Он рассхазывал о Капри. Сзади, (..) неслась струнная музыха. Неухели -- 3 дня назад я не знала этого голосаG? Глуховатого, тихого... (С. 657)

'He talked about Capri. String music was heard in the background. Did I really not know this voice $G$ three days ago? [Such a] low, quiet [roice]...' 
(70) Вы не мухчины, вы хрысы! [...] Вы хотите попрятаться по углам, но таких углов нет, они нандут вас всюду! Вы говорите: акдии не будет? А где восемьсот человех с Прорезноп улиды? Вы не знаете дорогуА $х$ яме? Вам $\theta$ послезавтра покажут, пропдете по неи в последнии раз. (Rb. 294)

'You are not men, you are mice! [...] You want to hide in the corners, but such corners don't exist, they will find you anywhere! You say: there won't be any action? Then where are the 800 people from the Proreznaja Street? You don't know the roadA to the pit? They will show it to you the day after tomorrow, you will go down it for the last time.'

In (69) the speaker feels that the voice which she heard for the first time sounds familiar; the text following the negative clause suggests the speaker's feeling that the type of voice described here as 'quiet and low' must have existed in her knowledge before. The negative interrogative, then, questions the existence of a certain type of voice.

In (70) the negative clause is part of the text where the speaker criticizes the people who were still afraid to rise up against the Germans and pretended to know nothing about what would happen to them (that is, they would be taken along the road to the pit and would be executed). In this context, then, the negative clause does not merely question the existence of such a road in the addressee's knowledge: rather, it questions the 
addressee's knowledge of the specific properties of the pit -- that they would be killed after going through it .. of all its possible properties and urges the addressee to take appropriate measures.

The situation with examples with abstract object NP's governed by neutral verbs is similar to the one with examples with concrete NP's governed by existential verbs.

3. 3. 4. Abstract Object NP's Governed by Neutral Verbs with

\section{Temporal-aspectual-modal Operators}

The following set of examples involves verbs in the perfective aspect: забыть 'to forget' implies a disappearance of a certain piece of information into oblivion, while зарыть 'to bury' implies covering up of a certain entity. 10

(71) Вах приятно сознавать, что вы, несмотря на мелхие неудачи, не зарыли вашего талантаG, а продолхали неустанно работать. (Ја. 82)

'How pleasant it is to realize that you, in spite of your small failures, have not buried your talent $G$, but have continued to work tirelessly.'

(72) Взяла Шатрова и сыграла на пороге своего семидесятипятилетия тридњатилетнюю!

Вак же было на самом деле? Я мучилась сомнениями? Терзалась? Лихорадочно твердила забитии техст?

Ничего этого не было. [...] 
Золотистия парих завили, тах же как завивали его двенаддать лет назад. Мон затылок по-прехнему долхен был доставлять удовольствие публихе. (...) Техст вспоминать не пришлось. Внутреннее развитие действия, задачи, кускиА не забила: техст возникал сам собон. (马. 352-353)

'S atrova took up and played a thirty-year old on the threshold of her seventy-fifth birthday!

How really was it? Was I tormented by doubts? Did I fall into pieces? Did I try feverishly memorizing the forgotten text? No such thing happened. [...]

The golden wig was curled up, just as it was curled twelve years ago. The back or my head, as before, was to bring satisfaction to the andience. [...] It was not necessary to work at remembering the text. I had not forgotten the internal development of the act, the problems, the pieces $A$ : the text came back on its own.'

The text in (71) is part of a congratulatory speech about the addressee's long successful career as an actress. This suggests that the speaker's focus is on the presence of her talent which remained unharmed. The negative clause in this context can be interpreted as reporting the total failure of the type of event (described in the negative clause), which left the talent intact.

The text of (72) hints at a general expectation that people could not play the role which they had played twelve years ago in 
exactly the same way, and that it would take time to recall the text. The negative clause, then, can be interpreted in the following way: 'While in most instances, one might be expected, in general, to have forgotten the internal development of the acts, problems, and pieces under such a circumstance, this is an exceptional instance in that (surprisingly) I had not done so'. Thus, the given situation is presented as a distinct situation out of a set of comparable situations.

Let us look at some examples with $G$.

(73) Сколько слез я пролила за это время -- описать нельзя. Главное, страдаю я, что ты, бедная, ходишь в старом пальто. Все время молюсь за тебя, а горяG не отвела. Твою шубку отдала вычистить, в субботу вечером пришла взять, а она вся в пятнах [...]. А мастера лгут, что тах и было [...]! (ङ. 63)

'How many tears have I poured during that time -- it is impossible to describe. Above all, I have been suffering from the fact that you, poor thing, are going around in an old coat. I have been praying for you all the time, but have not averted misfortuneG. I had turned in your fur coat for cleaning, came to pick it up on Saturday evening, and it has spots everywhere [...]. And the workmen lie and say that it had been like that $[. .$.

The negative clause in (73) introduces an episode about the unfortunate incident with the addressee's fur coat. The G-clause, 
then, is most appropriately understood as stressing the definitive absence of the type of event (managing to completely avert misfortune), which resulted in the incident.

Other examples which do not constitute minimal or even nearminimal pairs, but their semantic properties are similar to the examples cited thus far. $A$ is selected when the negative clause presents a distinct member out of a set, while $G$ is selected when the negative clause presents a set with no distinct members in it.

(74) Он [дедушка] видел его [Иосифа] насквозь: врет, будто дете увезли в Польшу, -- детен расстреляли; врет, будто где-то еше сохранились гетто, -- они уничтожены вместе с их обвтателямн; врет, будто немџы возьмут Мосхву и вонна скоро ковчится, -- они обещали взять Mоскву eme в охтябре. ХизньА им здесь никто не сохранит, все врет скотина, думает только о своен uкуре, а ве о спасенви люден. (Rb. 232)

'He [Grandfather] saw right through him [Iosif]: he lies [when he says] the children have been taken to Poland, -- the children have been shot; he lies [when he says] some ghettoes have been preserved somewhere, -- they have been eliminated together with their inhabitants; he lies [when he says] the Germans will take Moscow and the war will end soon, -- they had promised to take Moscow way back in October. No one here will preserve their life ${ }^{A}$, 
everything which the swine says is a lie, he is thinking only about his own skin, not about saving people.'

The negative clause in (74) is located in the grandfather's response to Iosif's texts about the people in the ghetto. The negative clause here can be interpreted as contrasting what Iosif, the alternative speaker, says (a set of the alternative speaker's texts) and the speaker's text about the status of the people in the ghetto. The negative clause can be read as follows: 'while Iosif presents all these texts related to the fate of the people in the ghetto, what my text ("no one will actually protect the life of our people") on the same issue is distinct from those of Iosif in that it carries the truth'.

(75) В феврале же 1926 года Радин одерхал вастоящую победу как ахтер и рехиссер в «Торговдах славон» [...].

Несколько повднее театра бывш. Корша эта пьеса прошла на сцене МХАТ под названием «Продавыы славы». Ставил ее молодои рехиссер Н. М. Гончарков, руководил постановкон К. С. Станиславскин.

В главных ролях: у нас -- Радин и Топорхов. В МХAT -- Лухскин и Вишневскин.

Невольное соревнованиеА театр бывш. Корша не пронграл.

Критик М. Загорския писал в «Новом зрителе» 23 июня 1926 года: 
«Каах это ни обидно, но все же приходится схазать, что актерски этот спектакль разыгран был значительно лучше в «Вомедии» [...], чем в МХAT. (\$. 190)

'In February of 1926 Radin sustained a genuine victory as an actor and director in "The Tradesmen of Fame" [...].

A little later than the former Kors Theater, this play went on stage of the MXAT under the name of "The Merchants of Fame". The young director N. M. Gončarkov directed it; K. S. Stanislavskij led the staging.

In the major roles: we had Radin and Toporkov, in the MXAT Theater - Lużskij and Višnevskij.

The former Korš Theater did not lose the unintentional competition A.

The critic M. Zagorskij wrote in The New Spectator on the twenty-third of June, 1926:

"No matter how annoying this is, still, one must say that in terms of acting this play was performed significantly better at 'The Comedy' than at the MXAT. [...]'

The text above emphasizes Radin's remarkable accomplishment as director and actor in 1926. This is reinforced by the text following the negative clause, in which a critic presents the fact that Radin's theater sustained the competition with MXAT as something impressive. The negative clause, then, can be interpreted as follows: 'while under normal circumstances, theaters like this might be expected to lose a competition with 
MXAT, in this particular case (because of Radin's excellent acting and directing) this theater did not do so'.

\section{3. 5. Summary}

Observations from sections 3.3.1 through 3.3.4 indicate that Aand A-clauses in the weak environments yield interpretations similar to those in the strong environments. G-clauses report a set of faceless members, while A-clauses report a distinct member of a set. In this section, however, uhlike examples in 3.1 and 3.2 , we have encountered more examples in which these two kinds of interpretation operate on levels other than the level of entity: on the level of property, on the level of temporal-aspectual-modal domains, and on the level of text. Also, the influence of context on the interpretation of the examples in this section is greater than on the interpretation of the examples in 3.1 and 3.2. In the strong environments, clause-level parameters nearly automatically impose specific interpretations. In contrast, in the weak environments $G$ is likely when the clause-level parameters and contextual interpretation line up, while $A$ is likely when there is a certain amount of contextual interference.

Contextual influence is also found in the weak environments favoring $\mathrm{A}$, which $\mathrm{I}$ will examine in the subsequent sections.

\section{4. Weak Environments Favoring A}

The following is the list of weak environments which favor A: 


\section{Table 30. Weak Environments Favoring A}

I. proper NP's governed by existential verbs in the imperfective present and past

II. object NP's cooccurring with temporal-aspectual-modal operators

1) concrete object NP's governed by neutral verbs

2) abstract object NP's governed by individuating verbs

3) concrete object NP's governed by individuating verbs

Both examples with the expected $A$ and with the unexpected $G$ will be analyzed.

\section{4. 1. Proper NP's Governed by Existential Verbs in the}

\section{Imperfective Present and Past}

The following are some examples with $\mathrm{A}$.

(76) Мпльк, дорого папа! Он всю жизнь хопил для детен, [...] в скопленное за хизнь распределил с трогательнов отровстов заботлхвостью и справеливостью. Я не помню МаринуА. Лёра плачет. На ней что-то черное. На gмпочках проходит Андрей. (C. 502)

'My dear Papa! He saved [money] for his children all his life, [...] and distributed what had been saved over his life with a touching fatherly thoughtfulness and fairness. I do not remember MarinaA. Laura is crying. She is wearing something black. Andrej walks by on tiptoes.' 
In the example above, the object NP names a unique individual; thus, already on the object level there is reference to a distinct member within a set. The context also seems to support this interpretation. The speaker retained other close family members in her memory. This reinforces the difference between the given individual and other individuals: the former, unlike the others, was not in the speaker's memory.

In the example below, the object NP also inherently presents a distinct member out of a set.

(77) Оспорить мохно -- все. Оспорят и это.

Я знаю все, что мне возразят, по-своему искахая и перетолховывая рассхазанную здесь правду. Эти люди не знали Марину А... (C. 758)

'One can question -. everything. This will also be questioned.

I know everything people will raise an objection to [me], distorting in their own ways and reinterpreting the truth told here. These people did not know Marina ${ }^{A} . . . '$

In addition to the inherent property of the proper NP, the clause is located in a context which reports that people misunderstood Marina. In other words, they did not know the most essential and true properties of Marina. The context, then. presents distinct properties among many properties attributable to the individual.

The following example, in contrast, has an unexpected G. 
(78) Помню, что я очень обижалась на Черневского, хоторын после спектакля упорно говорил: «Пусть Санечха не рассказмвает, что не видела Гликерии Николаевни ${ }_{\text {в }}$ «Много пума (из ничего]», не верю: нельзя, не видев, тах удачно сыграть.» (Ja. 102)

'I remember that I was very angry at Černevskij, who after the performance, adamantly said: "Don't let Sanečka say that she has not seen Glikerija Nikolaerna $G$ in "Much Ado [about Nothing]", I don't believe it: one cannot, without seeing her, play [the role] so successfully."'

The critic here insists that one would have to see how Fedotova acts in order to reproduce her acting so successfully. Then, the negative clause is understood as focusing on a set of properties which constitute Fedotova's acting (for example, intonation, gesture, voice, posture) rather than Fedotova as a distinct individual. The clause can thus be read as follows: 'she had not seen any of the properties of Fedotova in the play'.

The following example with $G$ yields a similar interpretation.

(79) Ио семи Ане в Парихе «Власть тьмы» играли четыре раза. От волнения и непосильного напряхения у нехоторих из нашнх артистов сел голос. Нехоторые на последнем спектакле свои роли буквально прошептали.

Я берегла нервы и голос. В день «Власти тьмы» с утра готовилась быть Матренон. В свободнын день 
отдыхала в номере. ПарихаG не видела... и вишло пообхчному: что Парих, что Серпухо -- все одно. (ड́.345) 'During the seven days in Paris they played "The Power of Darkness" four times. From agitation and excessive tension the voice of some of our actors went hoarse. Some literally whispered their roles during the last performance.

I spared my nerves and voice. On the day of "The Power of Darkness" I prepared myself to be Matrena from the morning on. On free days I rested in my hotel room. I did not see [any aspect of] Paris G... and things came out as usual: whether it is Paris or Serpuxoj -- it's all the same.'

In the example above, the object is a proper noun, which might be expected to refer to a unique entity. The context, however, seems to present Paris not as a distinct city within a set of cities. In this text, 'seeing Paris' is understood as seeing various cultural aspects of Paris which overwhelmed actors and distracted them from performing in their usual fashion. The negative clause, then, can be interpreted as reporting that the speaker saw none of Paris' overwhelming cultural aspects (properties) before her performances.

Similar interpretations are present in examples with concrete object NP's governed by neutral verbs with temporal-aspectualmodal operators as well. 


\section{4. 2. Concrete Object NP's Governed by Nentral Verbs}

\section{Cooccurring with Temporal-aspectual-modal Operators}

The following near-minimal pair contains the perfective verb С \& т $b$ 'to take off. The object NP's in both examples are referential and definite.

(80) Задержавшись, я могла бы явиться, как обычно являлась х Топорковым, одетая буднично, с лиром лоснящимся от вазелина. Торопясь, я не сняла легкия кондертний гримА [...] в ве переоделась. (క. 269)

'At the expense of arriving late, I could have appeared, as I usually appeared to the Toporkovs, dressed in daily clothes, with my face shining with vaseline. Being in a hurry, I had not taken off my light concert makeup $A[\ldots]$ and had not changed clothes.'

(81) И они сели, все еще дерхась за руки. Только тут Маша вспомнила, что она не снала плата и беретаG. C беретом дело было легхо поправить, она просто стряхнула его с волос левои, свободно рухоћ, но плащ невозмохно било снять, [...] (S. 31)

'And they sat, still holding hands. Only then it occurred to Maśa that she had not taken off the raincoat and the beret $\mathrm{G}$. With the beret the situation was easy to correct, she simply shook it off her hair with her left free hand, but it was impossible to take off the raincoat $[. . .]^{\prime}$ 
The context in (80) makes references to what the speaker usually did before going to the Toporkovs -- she would take off her concert make-up and change clothes. The gerund торопясі suggests that this was an unusual occasion in which the speaker had to hurry. The negative clause, then, can be read as follows: 'While on a number of other comparable occasions I took off my make-up, but this particular occasion was unusual in that $I$ did not'. In other words, the given occasion is presented as a distinct member of a set of comparable occasions.

In the context of (81) Maša notices the inappropriateness of wearing her coat; this is indicated by the adverbial только тут 'only then', implying that she should have taken off her garments long time ago. The negative clause can be interpreted as focusing on the fact that it had become definitively too late for the given action to be appropriate any longer. The clause suggests the unavailability of any more occasions in which her action of taking off her coat and beret is considered appropriate.

Let us look at another pair of examples. This one involves verbs which imply transfer of entities.

(82) Много вешен ношеных и белья -- [Георгия] оставил, сложив в узел, разрешил взять хозяезам.

--Мы обрадовались -- то время трудное было, вонна, ничего не достать, а у нас был маленькин ребенок, -сказала хозянка, -- но я не унесла узелА, оставила его там, где он был. А потом пришли какие-то два знакомые 
Георгия [...] стали рыться в вещах и на глазах унесли уэел с собон. (С. 721)

'[Georgij] left a lot of used clothes and linen, and having put them into a bundle, allowed the landlords to take it.

"We were overjoyed -- it was a difficult time, the war, you could not get anything, and we had a small child, -. the landlady said, -- but I did not take away the bundleA, I left it where it was. And then some two acquaintances of Georgij came [...] started to dig through the things, and took the bundle with them in front of my very eyes.'

(83) Портрет был загрыт парусннон, мне хотелось посмотреть, но я не поднял парусинк, завөрнул портрет в чистую мешковину, (..) и отправился х Ганху. (Rb.103)

'The portrait was covered with a piece of cloth, I had wanted to take a look, but I did not raise the clothG. I wrapped up the portrait into a clean sack, and went to Gajk.'

The text preceding the negative clause in (82) is about how the speaker needed the bundle and how glad she was when her tenant offered it to her family. In this context, the failure to take the bundle is an unexpected occasion. Then, the negative clause here can be viewed as presenting the given occasion as distinct from other comparable occasions: 'while a person under such a circumstance would take such a bundle right away, this occasion is unusual in that such a situation did not hold.' 
The text in (83) indicates that the speaker had wanted to see how his mother was depicted in the picture, but ended up not doing so before he carried it away; there was no other further occasion in which he could see it after that. The focus, then, is on the definitive absence of the type of event described and its consequence -- the speaker never had a chance to see the picture.

Just like in weak environments favoring $G$, case selection among examples containing concrete object NP's governed by neutral verbs with temporal-aspectual-modal operators is motivated not only by clause-level parameters, but also by context.

\section{4. 3. Abstract Object NP's Governed by Individuating Verbs}

\section{Cooccurring with Temporal-aspectual-modal Operators}

$A$ is slightly favored over $G$ in abstract object NP's governed by individuating verbs; the frequency of $G$, however, is by no means marginal.

Let us look at some examples with A.

(84) «Конечно, и у них тоже потери большие», -- подумал об артиллеристах и пехотиныах Климович, продолжая подниматься на бархан.

Но даже и эта мисль не смягчила его все нараставшее раздражениеА против командира стрелкового полка. Климович делил свои потери на те, что он должен был понести и понес, [...] и на те, что он понес иэ-за плохого взаимодеиствия с пехотой Оба 
сегодняшних танха, [..] могли бы и не сгореть, өсли 6 пехота с самого начала шла за танками вплотную, хах она ходила потом, хогда взяли этот бархан. (S. 211) "Of course, they, too, had great losses," -- Klimovic thought about the artillerymen and infantrymen, as he continued to climb up the sand-dune.

But even this thought did not soften his ever growing irritation against the commander of the infantry regiment ${ }^{A}$. Klimovič divided his losses into those which he had to suffer and suffered, [...] and those which he suffered out of poor coordination with the infantry. Both of today's tanks, [...] would not have burnt, if the infantry from the very beginning had been going closely behind the tanks, as it went later, when they took this sand-dune.'

The text following the negative clause above presents two categories of losses: the necessary losses which Klimovic had to bear and the unnecessary losses caused by poor interaction with the infantry. Klimovič's growing anger against the commander of the infantry regiment stems from the losses of the latter type. This suggests that the anger stemming from the losses of the former type would have been softened by the same thought. The reading of the negative clause is as follows: 'While this thought would have softened the type of anger stemming from the necessary losses, it did not soften this one (because it stemmed from the unnecessary losses)'. 
The following was the only interrogative clause with an individuating verb and an abstract object NP.

(85) $\mathrm{Kax}$ он [Сереха] горевал, что не успел мне поднять на четвертыи этах хирпичи! Умолял меня подохдать до завтра, [... -- а завтра он встанет и мне их внесет!

Разве тахие юноши не исхупали трудностиА эпохи? А столько их было, таких! В тон голоднон, героическон MockBe! (C. 634)

'How he [Sereża] grieved that he had not managed to carry the bricks up the fourth floor for me in time! He begged me to wait until tomorrow, [...] -- and tomorrow he would get up and bring them in for me!

Did such young men not redeem the difficulties ${ }^{A}$ of that period? And there were so many of such [young men]! In that hungry, heroic Moscow!'

The context seems to focus on presenting a distinct group of individuals in a set. The text preceding the negative clause above presents outstanding properties of a young man ( helped the speaker tremendously. The text following the negative clause emphasizes that there were many young men like Sereža. In this context, then, the negative clause can be interpreted as presenting those young people as a distinct group. The reading of the negative clause is as follows: '(there might have been other people in this hungry, heroic Moscow, but) is it not young men 
like Sereża who redeemed the difficulties of the epoch? (i.e., it is these who redeemed the difficulties of the epoch)'.

There are some examples with $G$.

(86) Наш театр теперь называется «Комедия РСФСР щ $3 »$, во вовая вывеска не изменила в судестве нашего делаG. вонечво, горы бумаг, масса гонтролеров, но художественная часть не подвергается значительнон ломке. Идет репертуар, с хоторым можно примириться: [...] (క. 152)

'Our theater is now named "Comedy RSFSR No. 3", but the new name did not in essence change our business $G$. Of course, mountains of papers, lots of inspectors, but the artistic part is not subject to significant change. Repertoire which it is possible to tolerate is being played.'

In the example with $G$ above, the object NP is modified, just like the examples with $A$ above. The negative clause thus can be potentially understood to present the entity as a distinct member of a set of various activities. The context, however, does not support this sort of interpretation. The text following the negative clause indicates that the main focus here is on the fact that the quality of the performance never dropped. In this context, then, the negative clause can be interpreted as reporting the definitive absence of the event, which left the important part of the theater untouched.

The following example is similar to the previous one. 
(87) Поэт пошутил. Луна не «канула», она не перестала быть тем, чем была для люден тысячелетиями, луннын свет не потерял своей поэтическо прелести. И планета марс оттого, что мы захинули на неө вымпел, ве изменила своего загадочного мерданияG. От познания храсота мира не убывает, а увеличивается. (క. 369)

'The poet was joking. The moon did not drop, it did not stop being what it was for people for thousands of years, the moonlight did not lose its poetic beauty. And the planet Mars, because we dropped a pennant on it, did not change its mysterious twinkling $G$. The beauty of the world does not diminish from knowledge, but increases.'

The text above is about the current state -- the unchanging beauty -- of the stars despite recent scientific discoveries in space. The focus of the negative clause, then, is on the definite absence of the type of event described by the negative clause, which left the mysterious twinkling intact.

The examples above again confirm that G-clauses yield an interpretation focusing on a set in which no member is presented as distinct, while A-clauses yield an interpretation differentiating a particular member of a set. The analysts of these examples indicate that not only clause-level parameters, but also context contributes to the generation of these interpretations. This will be further demonstrated in our last group of examples favoring A: 
concrete object NP's governed by individuating verbs cooccurring with temporal-aspectual-modal operators.

\section{4. 4. Concrete Object NP's Governed by Individuating Verbs}

Ceoccurring with Temporal-aspectual-modal Operators

Concrete object NP's governed by individuating verbs favor A strongly, but $G$ is still possible. Let us first examine clauses with $A$ in the perfective aspect.

(88) Они по своен беззаботности так еще и не успели до хонда устроиться с Машен, даже не отремонтировали комнату A. (S. 280)

'Sincov and Maša, because of their lightheartedness, had not managed to settle down completely, they had not even [completely] repaired the room ${ }^{A}$.'

The text preceding the negative clause (88) attributes Sincov and his wife's failure to settle down to their lightheartedness. This property presents these individuals as distinct from other comparable individuals, and consequently the negative clause can be read as follows: 'While people in similar circumstances would have already settled down, Sincov and Maša were so lighthearted that they have not even repaired their room.'

Presentation of a distinct member out of a set is also found in the following example with $A$.

(89) В хвартире матери погибли бумаги моего отва с письмами Репина, Куинджи и других. Чудом уделела библиотеха в глубокои стенно нише: у обессиленных 
ГОЛОдом Люден не хватило сил ОтОдвинуть загораживавши нишу тяхеленнын зеркальнин шхаф. КнигиА не сохгли. (Kr. 314)

'In my mother's apartment my father's papers with letters of Repin, Kuindži, and others were destroyed. The library in the deep niche in the wall survived miraculously: the people who had been weakened by hunger did not have energy to take away the heavy mirrored closet which was barricading the niche. They had not burnt the books ${ }^{A}$.'

The plural form of the object NP in (89) indicates that the NP may be interpreted as representing a set without differentiating any of its members. The text preceding the negative clause, however, suggests that most of the belongings of the family had been destroyed. In this context, then, the negative clause can be interpreted as follows: 'unlike other things which they had burnt, they did not (manage to) burn these books'.

Let us now turn to examples with $G$. The following example, like the two previous ones, is in the perfective aspect.

(90) Играя Шуру Лебедеву, я ненавидела мелких людишек, охрухавших Иванова; беря его под защиту, бросала вызов обшеству. Мон резкия тон не удовлетворил редензета, но я тонаG не изменила. «Резкости» от меня требовал Н. Н. Синельников. (Ј. 337)

'Playing Ś ura Lebedeva, I hated petty people who surrounded Ivanov; taking him under my protection, I 
threw down a challenge to the society. My harsh tone did not make the reviewer happy, but I ended up not changing the toneG. N. N. Sinel'nikov had demanded "harshness" from me.

The text surrounding the negative clause in (90) presents the speaker's strong determination to preserve the harsh tone. This is manifested in the speaker's detestation of petty people and Sinel'nikov's instruction to act with "harshness". In this context, the negative clause is interpreted as emphasizing the total absence of the desribed event, which left the harshness intact.

Another similar example follows.

(91) В начале зимнего сезона -- снова рехиссерсхая работа. Ввоху на роль генерала Стесселя В. П. Шарлахова. [...]. Ввод оказался удачным, Шарлахов спектакляG не посрамнл. Но я все хе огорчена: зачем велихолепному агтеру Зубову изменять своему истинному призванию? (క. 324)

'At the beginning of the spring season -- a director's work again. I bring in V. P. Śarlaxov for General Stessel's role las a substituting actor]. [...] The substitution turned out to be successful, Šarlaxov did not disgrace the playG. But I am still embittered: why does a great actor like Zubov have to betray his true calling?'

The text in (91) refers to the successes of the substitution. The negative clause then can be considered to emphasize the 
definitive absence of the described event, which left the play unharmed.

The following contains a verb in the perfective past.

(92) -- Вахая ты странная! -- схазала, негодуя, Марина. -Почему ти не остановила трамванА, не вызвала милицнонера, не составила акт? Был хе хоть один храсвоармеев в трамвае -- в шлемө! Не заявила, что ты -

- член Союза писателен, [...] (С. 638)

"How strange you are!" Marina said, indignantly. "Why didn't you stop the streetcar ${ }^{A}$, call for the militia man, make a complaint? There was at least one Red Army man in the streetcar -- wearing a helmet! You didn't announce that you were a member of the Writers' Union, [...]'

The negative clause above is part of Marina's quote in which she evaluates her sister's behavior as strange; in Marina's view it is obvious that she should have stopped the streetcar on such an occasion. The negative clause, then, can be interpreted as follows: 'While on such occasions you are expected to make a complaint, it is strange that you did not on this particular occasion.'

The example below is a counterfactual clause which contains a verb in the perfective aspect, but the object $N P$ appears in G.

(93) -- Я сам сегодня одними убитыми девятнадыать человек потерял,-- с сердџем сказал Красюк. 
-- И свонХ столько не потөрял би, өсли би днем тех танковG не схег,-- безхалоство схазал молчавшии до chx nop Caekxo. (S. 216)

"[Counting] only the dead, I myself lost 19 men today," Krasjuk said in anger.

"And you wouldn't have lost so many of yours, if you hadn't burnt those tanks $G$ during the daytime," Saenko, who had been silent until then, said mercilessly.'

The object NP here is in the plural form, which does not differentiate a specific member out of a set of tanks; nonetheless, the noun is modified and can also be considered as presenting a specific group of tanks out of a set. In this context, however, the focus of the argument between the two officers is on the quantity of men and tanks lost in the given battle. The tanks have referents, but to these officers it does not matter which tanks they lost; the .entities are thus not presented as distinct members of the set of given tanks in terms of some special property, but as tanks which could have been available in the battle --'if there had been a sufficient number of tanks. Krasjuk would not have lost his men (but in reality since he was deprived of some of his tanks, he lost his men). The negative clause comments on the existence of some tanks lost, but do not distinguish them out of a set in terms of any specific property. 


\section{4. 5. Summary}

The examples from this section confirm that $G$ is correlated with reference to a general set which consists of members, without presenting any of them as distinct, while $A$ is correlated with reference to a distinct member of a set. The examples in 3.4 are similar to those in 3.3 in two respects. First, in many of the examples from both sections the two types of interpretation operate not only on the level of entity, but also on other levels. Second, there is much contextual influence on the interpretation of many of the examples from both sections. What is different about the weak environments favoring $A$ and the weak environments favoring $G$ is that contextual interpretation lines up or interferes with clause-level parameters in different ways. In the environment favoring $G$, contextual interpretation and clauselevel parameters tend to line up to trigger $G$, while contextual interpretation tend to interfere with clause-level parameters to trigger $A$. In the weak environments favoring $A$, contextual interpretation and clause-level parameters tend to line up to trigger A, while contextual interpretation tend to interfere with clause-level parameters to trigger $G$. In section 3.5 I will examine the other remaining weak environments.

\section{5. Other Weak Environments}

The following is the list of other weak environments. For the first group of environments, there was not sufficient data to 
determine which case was favored. The environment with concrete object NP's governed by individuating verbs in the imperfective past and present appears to allow $A$ and $G$ equally.

\section{Table 31. Other Weak Environments}

1. proper NP's cooccurring with emphatic negation

II. concrete object NP's governed by individuating verbs in the imperfective past and present

\section{5. 1. Proper NP's Cooccuring with Emphatic Negation}

To this point we have observed that A-clauses report a distinct individual out of a set, while G-clauses report a set of entities without any specific properties. It is interesting to see what happens when strong parameters inherently triggering these two interpretations cooccur. Proper nouns refer to unique individuals, while emphatic negation emphasizes the absence of any distinct individual within a set. Instances in which the two parameters cooccur are not numerous, as shown in Tables 22-24, but they occasionally occur in 'neither...nor...' constructions, which do not necessarily yield a nonreferential interpretation of the object NP. Case selection in these examples seems to be heavily dependent on context.

Examples (94) and (95) have proper object NP's and existential verbs.

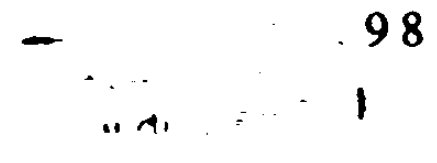


(94) Натура Маруси взяла верх над болезнью: она поправилась. Во все те зимние и полувесенние дни я не помню ни папы, ни ЛерыG. Может бить, они вавоеі өздили по городам Италин? (С. 116)

'Marusja's nature gained the upper hand over the illness: she recovered. During all those winter and early spring days I remember neither Papa $G$ nor LauraG. Maybe they were travelling together in the cities of Italy?'

In the example above, the verb, on the one hand, inherently implies a set of entities with no distinct properties in the cognitive domain; proper NP's, on the other hand, inherently imply the presence of various properties differentiating a specific entity out of a set. Here, context seems to line up with the former. The text following the negative clause indicates that the speaker is interested in these two individuals' property -- in what these two individuals were doing -. during the time of Marusja's illness; this is indicated by the reference to traveling in Italian cities as their possible property. Thus, the negative clause is best interpreted as focusing on the unavailability of any property (in the speaker's memory), concerning these individuals during the given period of time; in other words, the speaker knows that there is a set of properties regarding these individuals, but she cannot retrieve any of them.

The following example is similar to the one above. 
(95) Но и трех строх нечем заполнить мне о лете 1906 года после смерти мамы. Я не помню ни Добротворских в то лето, ни Тетй, ни наших домашних на даче, ни отъевда маруси в Москву (веровтно, с Лёрон и Андргіе $x$ вачалу учения). (С. 223)

'But I do not have anything to fill even three lines about the summer of 1906 after Mama's death. I remember neither the Dobrotvorskijs, nor AuntieG, nor our family members at the dacha, nor Marusja's departure for Moscow (probably, with Laura and Andrjuša towards the beginning of her study).'

In the example above, the text preceding the negative clause emphasizes the lapse of memory about the days after the speaker's mother died. The negative clause, then, can be interpreted as focusing on the fact that there should have been some properties regarding these individuals during those days, but none of them is available in the speaker's memory.

In contrast to examples with $G$, texts cooccurring with $A$ reinforce the interpretation focusing on a distinct member of a set, as in the following example.

(96) -- [...] Тн что, собираешься посадить мне еще девчонку на голову? Этого не будет никогда! (...)

И решил я поговорить с отыом. Отеम не видел ни олюА, ни Анну МоисеевнуА, в наши с мамои споры не 
вмешивался. И хогда остались мы один на один, я ему говорю:

-- Что-то надо решать с Олей.

-- Забрать? -- спрашивает отед и смотрит на меня. [...] И хотя он схазал только два слова: «Надо подумать», -- я понял, что отед на моеи стороне. (Rb. 150)

"m[...] Are you planning to put yet a girl on my head? This will never be! [...]"

And I decided to talk with Father. Father had seen neither $\operatorname{Olja}^{A}$, nor Anna MoiseevnaA, he did not interfere with the arguments between Mama and me. And when we were alone, I say to him:

"One must do [lit. decide] something with Olja.

"To take [her]?" asks Father and looks at me. [...] And although he only said three [lit. two] words: "[We] have to think [a bit]," -- I saw that he was on my side."

Here, too, proper nouns occur as objects of a perception verb. The context, however, is different from the one in the previous example. In this episode, the speaker and his mother have an argument over what to do with the orphaned Olja. The speaker's mother refuses to have anything to do with Olja because she had been treated coldly by Anna Moiseevna, Olja's mother, in the past. The speaker, who wants to help out Olja, then goes to talk to his father in order to obtain his father's support on this matter. This is indicated by the text following the negative clause $([\ldots]$ я понял, 
पто отед на Moek cтopoke. '[...] I saw that Father was on my side'). In this context, then, the negative clause can be interpreted as follows: 'Father, in contrast with Mother, had seen neither Olja nor Anna Moiseevna, (and was more likely to support my attempt to help out Olja; consequently I decided to talk to him).' Thus, the negative clause can be viewed as presenting Father distinct from Mother in that he had not seen these two individuals.

The following example is somewhat different from the previous two in that it contains a neutral verb.

(97) Публиха мевя [в роли Дхессихи] попросту не заметила. [...] (క. 66) [...]

После «पанхи» Иван Мировович поздравил меня и вах но замөтил:

-. У вас дело поддет! [...]

Сияельнихов-старшия, наверное, тохе надеялся, что В гонде хондов у менд «дело пондет».

Ни ДхессихуА, ни ЗаречнуюА у меня не отобрали, над отдельними сиенами из "Чанки" Синельников продолхал работать со мнон и после премьеры, в свободние часк. (З. 69)

The audience simply did not notice me lin the role of Jessica]. [...] (66)

After "The Seagull" Ivan Mironovič congratulated me and remarked with authority:

"Things will work out for you!" 
Probably, Sinel'nikov Sr. was also hoping that in the end things would work out for me.

They took away neither JessicaA nor ZarečnajaA from me, Sinel'nikov continued working with me on separate scenes from "The Seagull" even after the premier, in his spare time.'

Here, too, clause-level parameters strongly conflict. On the one hand, the verb 'to take away' tends to imply that the entity exists independently of the event, before being removed; proper nouns presuppose various properties which differentiate the given roles from others; on the other hand, emphatic negation 'neither..., nor...' emphasizes that neither of the two entities had the property described by the verb. Context seems to determine case selection here. Prior to the negative clause within this episode, there are references to the speaker's bad performances of Jessica and Zarecnaja. This is followed by a text about the existence of people who, to the speaker's surprise, were nonetheless supportive of her. This context, then, suggests that, the situation presented by the negative clause was an exceptional case, different from what usually would take place. The clause can thus be read as follows: 'while in similar circumstances people would take roles away from actors/actresses who perform badly, in this specific circumstance (which is marked by exceptionally strong support from several people), the people at the theater took away neither Jessica nor Zarečnaja from me.' 
The examples above suggest that, when proper object NP's occur with emphatic negation, case selection involves a high degree of contextual reinforcement for one of the two interpretations: one which distinguishes a member out of a set, and the other which refers to a set of faceless entities.

Thus far we have looked at examples in which clause-level parameters compete. Let us now examine the one environment in which the frequencies of $A$ and $G$ are almost equal.

\section{5.2. Weak Environment Which Does Not Favor One Case in}

\section{Particular}

According to my data, there is one environment in which neither $A$ nor $G$ is favored: concrete object NP's governed by individuating verbs in the imperfective past and present. Let us look at some of the examples.

(98) «Трагедию мало ситрать, -- говорил Мунэ Сюлли, -- ее надо еде и протандевать». Висодхая не «тандевала», ио пластично двигалась в велихолепно жестихулировала. Ова не извивала торсА в «трагических конвульсиях», не корчилась -- ее позы были монументальвы, выразительны, хесты прекрасны. (Кг. 73)

'It is not enough to play a tragedy, -- Mune Siulli said, -one must dance it as well". Vysockaja did not 'dance', but rhythmically moved and gesticulated magnificently. She did not twist her torso ${ }^{A}$ in "tragic convulsions", she did not 
contort herself -- her poses were monumental, expressive, her gestures were superb.'

In (98), the text preceding the negative clause suggests that there was a general notion that actresses should "dance tragedy", including twisting torsos. The negative clause, then, presents Vysockaja as a distinct member of a set of tragedy actresses in that she did not dance and did not twist her torso.

The following example is similar to the one above.

(99) Его горячо любили московские зрители, но он был «неугоден» начальству, тах как нихогда не гнул перед ним спинуА, ненавидел подхалимство, был честным и независимым человехом. (Ја. 112)

'Moscow viewers loved him vehemently, but he was "inappropriate" for the authorities, since he never bent his back $^{A}$ in front of them, hated boot-licking, he was an honest and independent person.'

Object nouns denoting body parts are said to have a tendency to appear in A (Borras and Christian 1971/79:29). Nonetheless, context, in addition to this inherent property of the object, seems to contribute to case selection here: (99) is a text about Xoxlov's special properties -- he was independen'-minded, honest, and therefore no good for the authorities; the negative clause elaborates these properties. In other words, the negative clause can be interpreted as presenting Xoxlov as a distinct individual in terms of the given property ('while it is assumed to be 
appropriate that actors bend their backs in front of the authorities, Xoxlov was inappropriate in that he did not').

The following example also has an object NP referring to a body part but has G.

(100) Ну и выдал он мне тоГда! Не повышал голоса, он вообще не повышал голоса, сел против меня и схазал, что поэзия хороша тогда, когда она полезна делу пролетариата, если же она не полезна, значит, это вредная поэзия. (Rb. 82-83)

'Well, he let me have it then! He did not raise his voiceG, he did not raise his voice $G$ in general, sat across from me and said that poetry is good when it is useful to the cause of the proletariat, but if it is not useful, then, it is harmful poetry.'

In the example above, the text preceding the negative clause indicates that the speaker was about to talk about how his brother scolded him. The negative clause then can be interpreted as responding to the addressee's expectation of an event in which the brother raised his voice in anger at some point(s) during the given period of time. The adverb вообщe 'in general' indicates that there never existed any point throughout the given temporal-aspectualmodal domain at which such an event took place.

Let us now compare negative clauses with plural object NP's.

(101) На втором курсе Яковлева сменил Александр Акимович Санин, режиссер Драматического театра. Санин не полонял наши сердуаА, хак Петровския, не 
восхищал артистизмом, подобно Яковлеву. Но мы любили и Санина. (З. 50)

'In the second year Jakovlev was replaced by Aleksandr Akimovič Sanin, director of the Drama Theater. Sanin did not captivate our hearts ${ }^{A}$, like Petrovskij did, he did not carry [us] away with his artistry, like Jakovlev. But we liked Sanin as well.'

Here, the noun phrase following the conjunction $\mathrm{x}$ a $\mathrm{x}$ Петровски 'like Petrovskij' in the negative sentence indicates that Sanin is presented as distinct from Petrovskij. The text following the negative clause refers to yet another individual Jakovlev and this further indicates that the speaker's focus is on the difference between Sanin and other instructors.

The following is an example with plural nonreferential object NP appearing in G.

(102) Мы никогда не дећствовали в одиночку, не выдвигали свой образ в ущерб остальным, не подчеркивали «выигрышных》 мест в своеи роли. Если По ходу Дейтвия начинается «моя суена», то-есть в неи доминирую я, то остальные должны мне подыгрывать, если же идет суена другого актера и он доминирует, то я лишь подыгрываю ему. (Ја. 70)

'We never acted alone, did not push our own image at the expense of the others, we did not emphasize the "flashy" places $G$ in our role. If in the course of the act there begins 
"my scene", then I become the main character, then the others should support me with their acting; if, on the contrary, there goes a scene of another actor and he becomes the main character, then I merely support him.'

In this example, the object NP is modified but nonreferential. This example thus does not form a near-minimal pair with the immediately preceding one, but it is possible to see how context yields an interpretation different from that in (101). Here, flashy places are those places which make the individual actor or actress look good but which should not be emphasized for the sake of the whole play. Since the context is about how well the actors and actresses cooperated, the negative clause is best understood to focus on the complete absence of any single flashy place which was unnecessarily emphasized.

\section{5. 3. Summary}

The examples above again confirm observations concerning the interpretations of A- and G-clauses from previous sections: Aclauses distinguish a specific member (an unusual or exceptional member) out of a set, while G-clauses report a set of members without specific property to differentiate any one of them. As in examples from 3.3 and 3.4 , these two types of interpretation operate on different levels. The examples from this section do not constitute strict pairs, but they nevertheless suggest a high degree contextual participation in invoking such interpretations. 
In the subsequent section I will describe in more detail the semantics of A- and G-clauses. I will also suggest the relationship between case selection and discourse.

\section{6. Semantics of A- and G-clauses and Their Relationship to Discourse}

The quantitative results and the analyses of individual examples have indicated that case selection may be determined on roughly two different levels: primarily on the basis of clauselevel parameters, or a combination of clause-level parameters and context. When strong clause-level parameters are present, context usually does not interfere with case selection; when strong clauselevel parameters are not present, context tends to participate in case selection. We have observed, however, that, in spite of the different degrees of contextual influence, similar semantic operations take place in case selection. The following discussion of clauses with $A$ and $G$ addresses this similarity.

\subsubsection{Semantics of A-clauses}

The analyses of my quantitative data and the individual examples indicate that the occurrence of $A$ is motivated when the negative clause presents a distinct element in context of a set of elements. This is graphically represented as follows: 


\section{Figure 7. Semantics of an A-clause}

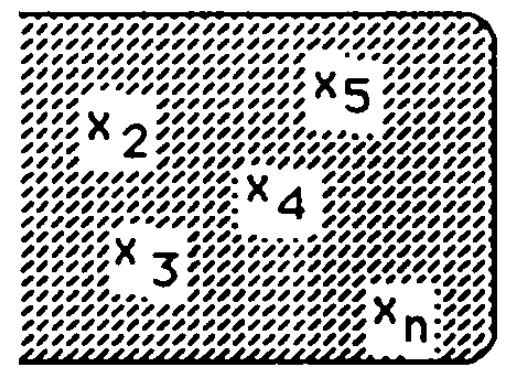

The A-clauses implicitly present the given element $x_{1}$ as exceptional or unusual from other members $\left(x_{2} \ldots n\right)$ within a set $X$; this process of presenting a specific member as distinct can be considered individuation, to use Timberlake's term. Individuation (IND) has been perceived as a property of a noun, but it can be realized on several different levels, as listed in the following table.

\section{Table 32. Individuation (IND) Operating on Different}

\section{Levels}

1. IND on the level of lexicosemantic properties of constituents

1a. IND on the level of individual or entity (INDent)

1b. IND on the level of property (INDprop)

2. IND on the level of temporal-aspectual-modal domains (INDasp)

3. IND on the level of text (IND'xt) 
When individuation operates on the level of individual or entity, the negative clause presents the given individual or entity (INDent) or the given property ((INDprop) as a member distinct from the other members of the set.

INDent contrasts the given entity and other possible entities in terms of some property or properties. It tends to operate when the object NP is referentially unique. Proper nouns typically refer to unique individuals; the properties distinguishing a particular individual or individuals from other members of the set are assumed to be known to the addressee. Individuation of an entity, however, may be realized not only by proper nouns.

The example below contrasts two kinds of people: young people and old people. The latter is differentiated from the former in that they could not possibly come up with a name like "Konstapso".

(103) Название театра «Констапсо» -- coxpaщенное «конура старых псов». Были мы все молоды. Старые такое названиеА, наверное, не придумалибы!(క. 171)

'The name of the theater is "Konstapso" -- the abbreviated "konura staryx psov [the kennel of old dogs]". We were all young. Old people probably would not come up with such a nameA !'

Individuation on the level of property (INDprop) is the other type of individuation on the level of lexico-semantic properties of constituents; in this case, a negative clause presents the given 
property as distinct from other possible properties which hold for the same individual or entity.

The negative clause below (as discussed in (77) earlier) yields the following reading: 'these people did not know more crucial and essential properties of Marina (in order to understand my view), while they might know the less important ones'; here, then, the object NP presents distinct properties of Marina -- her essential properties -- in a set of properties regarding the individual, rather than presenting Marina in contrast with other possible individuals.

(104) Эти люди не знали МаринуА. (С. 758)

'These people did not know MarinaA.'

When individuation takes place on the level of temporalaspectual-modal domain (INDasp), the given event is typically presented as a member distinct from other members of a set of comparable events conceived as possible in some world.

In the following example two conditions are contrasted: in other comparable instances, a person in Anna Egorovna's position (or even Anna Egorovna herself) might have been expected to follow the mistress's order and slam the door closed; but in this particular instance (involving the close relatives of her master), Anna Egorovna did not do so.

(105) И я понял, что Анна Моисеевна [...] нахазала не пускать в дом. [...] 
Но Анна Егоровна растерялась, не захлопнула перед нами дверьА, добрая женшина не смогла этого сделать, впустила, но провела не в комнату, а на хухню. (Rb. 122) 'And I understood that Anna Moiseevna [...] she had ordered her not to let us into the house. [...]

But Anna Egorovna did not know what to do, she did not slam the $\operatorname{door}^{A}$ closed in front of us, the kind woman could not do this, she let us in, but led us not into the room, but into the kitchen.'

When individuation operates on the level of text (IND'xt), the negative clause presents the given text as distinct from all the possible texts which may potentially occur at the given point of discourse. Below is an example of INDixt. As discussed in (74), the negative clause here can be interpreted as contrasting the texts presented by the alternative speaker (losif) and the speaker's text related to the same issue (the fate of the people in the ghetto).

(106) ЖизньА им здесь никто не сохранит, все врет схотина, думает только о своеи шкуре, а не о спасении людеи. (Rb. 232)

'No one here will preserve their life $\mathrm{A}^{\mathrm{A}}$, everything which the swine says is a lie, he is thinking only about his own skin, not about saving people.'

\subsubsection{Semantics of $\mathrm{G}$-clauses}

G-clauses invoke a set of elements without distinguishing any of the members in it. I will call this type of interpretation of a 
negative clause the existential interpretation (EI). Thus, the general graphic representation of this interpretation is the following:

Figure 8. Semantics of a G-clause

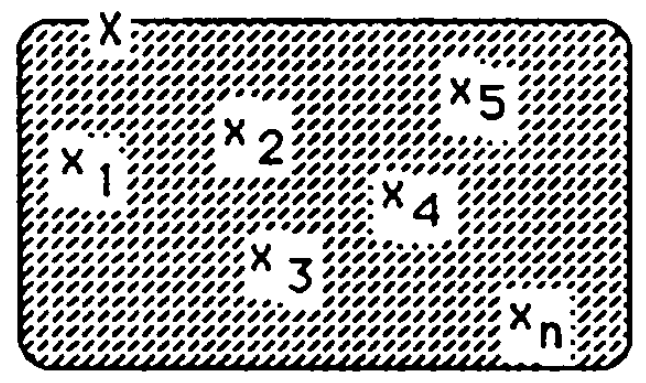

The negative clause first invokes a type or set of entities $X$ and denies or reports the existence of its members $\left(x_{1} \ldots n\right)$, without distinguishing any particular member or members from others. This type of semantic operation takes place on different levels, as shown below.

Table 33. Existential Interpretation (ED) Qperating on Different Levels

1. EI on the level of lexicosemantic properties of constituents

1a. EI on the level of individual or entity (EIcnt)

1b. EI on the level of property (EIprop)

2. EI on the level of temporal-aspectual-modal domains (EI ${ }^{\text {asp })}$

3. El on the level of text (EItxt) 
When an existential interpretation operates on the level of lexicosemantic properties of constituents, the negative clause may invoke a set of entities or individuals (EIent), or a set of properties which might hold for the given individual or entity (EIprop), without distinguishing any of them.

When an existential interpretation operates on the level of individual or entity (EIent), a negative clause with $G$ can deny the existence of any entity or individual of the type characterized by the object NP.

(107) [..] но он был служащин, ни однои копеики сверх жалованья не имел. (Rb. 46)

'[...] but he was an office worker, he did not have a single kopeck $G$ above his salary.'

This type of El may be viewed as being in direct opposition to INDent (exemplified by (103) above), in which one specific entity is presented as distinct from all the other entities within the set.

The other type of existential interpretation on the level of lexicosemantic properties of constituents, (EIprop) assumes the existence of the given individual or entity and focuses on the unavailability of any possible properties which might hold for this individual or entity in a certain domain, as in the following example (repeated from (78)). Here, the negative clause focuses on a set of properties which constitute Fedotova's acting (for example, intonation, gesture, voice, posture) rather than Fedotova as a distinct individual. The clause can thus be read as follows: 
'she had not seen any of the properties of Fedotova in "Much Ado [about Nothing]"'.

(108) Пусть Санечка не рассказывает, что не видела Гликерии Нихолаевны $G_{B}$ «Много шума [из ничего]», не верю [...]. (Ja. 102)

'Don't let Sanečka say that she has not seen Glikerija NikolaevnaG in "Much Ado [about Nothing]", I don't believe it: $[\ldots]^{\prime}$

This type of El may be viewed as being in direct opposition to IN D prop (exemplified by (104) above), in which one specific property is presented as distinct from all the other properties within the set.

When an existential interpretation operates on the level of temporal-aspectual-modal domains (EIasp), a negative clause can imply that there were many occasions within the given temporalaspectual-modal domain on which the given event could have happened, but that such an event took place on none of these possible occasions, as in the following example.

(109) Никому я своего настроенияG не показывал. И никто ничего не заметил, кроме матери. (Rb. 160)

'I did not show my moodG to anyone. And no one noticed anything, except for my mother.'

The speaker has in mind a certain stretch of time during which showing of his emotion could have taken place, but it did not at any of the possible points (or possible occasions) in the temporal- 
aspectual-modal domain. Elasp, then, can be viewed as being in direct opposition to INDasp (exemplified by (105)); the former invokes a set of occasions without distinguishing any of its members, while the latter presents one specific occasion as distinct from all the other possible occasions.

I have claimed above that negative clauses with A may yield INDixt in which the given text is presented as distinct from other possible texts which may occur at the given point of discourse. EItxt, an existential interpretation directly opposed to this interpretation, is possible when the negative clause denies the existence of any of expected texts related to some episode or theme.

In the example below, the sentence in parentheses indicates that texts related to religious education are often presented in memoirs. The negative clause can therefore be interpreted as denying any of such texts which the reader probably expects in the speaker's text.

(110) Религиозного воспитанияG мы не получали (как оно описывается во многих воспоминаниях Детства -уерковные традидии, усердное посещение уерквеи, молитвы). [...]

Зато нравственное начало, вопрос добра и зла внедрялись мамой усердно [...] (C. 56)

'We did not receive any religious education $G$ (as it is described in many memoirs of childhood -- ecclesiastical 
traditions, diligent visits [lit. diligent visit] to churches, prayers). [...]

Instead, the basis of morality, the question of good and evil, were taught by Mama diligently [...]'

It seems that existential interpretations on other levels line up with Eltxt. The Eltxt in the example above cooccurs with Elent: 'There was nothing which can be characterized as religious education that we received'. Such a cooccurrence with EI on another level seems natural; the speaker, while denying the existence of the sort of text expected by the addressee, he/she may deny the existence of various elements constituting the text which are expected by the addressee. .

To reiterate, A-clauses present a member as distinct in context of a set, while G-clauses present a set of members that are not differentiated by any specific properties and report the existence or nonexistence of any members. Both interpretations may operate on different levels: on the lexico-semantic level, on the level of temporal-aspectual-modal domains, and on the level of text.

These observations not only confirm, but also make more precise Tomson's intuition that A-clauses make implicit reference to the corresponding affirmative (1903), by showing that reference to the corresponding affirmative clause occurs on different levels of the semantics of the negative clause. Tomson's observation that G-clauses have a descriptive function has also 
been confirmed and elaborated here. G-clauses describe or characterize the type of individuals, properties, occasions, and texts. I have also shown that the notion of individuation proposed by Timberlake (1975) can be extended to account for semantic operations not only at the noun phrase level, but also at more abstract levels.

\subsubsection{Discourse Considerations and $A$ - and $G$-clauses}

To the extent that A-clauses distinguish a distinct (exceptional) member out of a set, the speaker assumes that the addressee entertains some property $P$ about a set of elements. A-clauses, then, are likely to have the function of revising the addressee's knowledge by singling out an exceptional member out of this set for which the property $\sim P$ holds. G-clauses, in contrast, may be used when the speaker assumes that the addressee might entertain the existence of a set of elements with a property $P$ in a certain domain. G-clauses may therefore report the nonexistence of any of such elements in the domain. Clearly A-clauses and Gclauses modify the addressee's prior knowledge, but they do so in different ways.

This relationship between discourse and A- and G-clauses also suggests that morphosyntactic variation reflects discourse operations which are finer than the distinction between presence and absence of "evaluation" or highlighting (Labov 1972, Polanyi 1985), or between backgrounded and foregrounded information (Hopper and Thompson 1980). Both A- and G-clauses are capable 
of presenting some unexpected situation and therefore present information "worth conveying," but they revise the addressee's knowledge in different ways. 11 


\section{Notes to Part I}

1. 522 examples were collected manually and 1210 from scanned texts.

2. Previous quantitative results show very little significance of morphological number in the object NP (Restan 1960:97, Green 1979:161, and Haka 1981). This is one of the reasons why this parameter has not been considered for testing. There was also a technical problem in testing the relevance of this parameter to the whole corpus. The chi-test requires that each example fall into one and only one category (Hatch and Farhady 1982). The opposition "singular vs. plural" exists only in a particular group of nouns (primarily concrete nouns); since the corpus includes nouns which do not have this opposition and would have to be labeled "not applicable", this property was not tested for the whole corpus.

3. I used Haka's data quoted in Mustajoki 1985: 51, 54, 58, 61, $65,75,95$.

4. Constructions with $\mathrm{R}$ К absence of any entity which fits the description of the property presented by the object NP; that is, they emphasize the absence of any member of the given type or set of entities described by the object NP. The construction ни..., ни.... may be construed as slightly different from these two constructions; ни $x$, ни у у ... may emphasize the nonexistence of any of the members within a set $\{x$, $y, \ldots z\}$ (or $\{x, y, \ldots\}$ ) which fit the property presented by the verb. 
All three types of constructions, however, are similar in that they emphasize the absence of an entity within a set.

5. Here I assume that some animate nouns are either incorporated into proper nouns or into concrete nouns.

6. This category of verbs may appear to constitute a large class, but, as Tables 22-24 indicate, the number of examples belonging to this group in my corpus was not exceedingly large to be compared with examples with other verbs.

7. As for the environment "proper NP's cooccurring with emphatic negation", the number of examples was too small to be safely considered automatic; I will treat the combination in section 3. 5. 1, together with those environments which are labeled as "other weak environments".

8. Admittedly, in this type of analysis there is no pair where every single variable is identical except for one. This is the reason why I call these examples "near-minimal".

9. One might argue that there is a possible contrast between the occasions on which Nikolaj did not skip the performances and the specific occasion on which he did. Nonetheless, what is being emphasized as unusual or exceptional (and therefore individuated) is not the former, but the latter. Clearly the given negative clause does not present the event as distinct from the others, but reports many (indistinguishable) occasions in which Nikolaj did not skip the performances. 
10. For justification for treating the examples as members of a near-minimal pair, see Janda (1985).

11. Hopper and Thompson (1980) argue that negation and objects with low degree of individuation tend to correlate with backgrounding, while highly individuated objects tend to correlate with foregrounding.

The present analysis demonstrates that negation and high degree of individuation of the object, two of the conflicting "transitivity" parameters, or more interestingly, negation and low degree of individuation of the object, which are said to correlate with background information, may line up to present informationally significant texts. Sequentially ordered events are said to be foregrounded information, and tend to be viewed as constituting the main thread of discourse and consequently as being informationally prominent, but my results seem to indicate that this might not always be the case, and that the so-called background information is heterogeneous and may carry significant or prominent information; similar observation is made also in Kalmár 1982:242. 
Appendix 1 to Part I: Existential and Individuating Verbs

1. existential verbs

1) verbs of possession and discovery встречать/встретить 'to meet, encounter' дерхать 'to hold' заставать/застать 'to find' находить/натти 'to find' нести, носить 'to carry on foot' חодLскатв 'to seek out, find'

2) verbs with an effected object внушать/внушить 'to inspire, instill' вызывать/вызвать 'to provoke, cause' говорить/схазать 'to say' готовить/приготовить 'to prepare' делать/сделать 'to make' думать 'to think' заявлять/заявить 'to announce, claim' мыслить 'to conceive, think' писать/написать 'to write' предлагать/предложить 'to offer, suggest' представлять/представить (себе) 'to imagine' придумать 'to think up' произносить/пронзнести 'to pronounce' слагать/сложить 'to compose' 
составлять/составить 'to put together'

щить/сшить 'to sew'

3) verbs of approval and tolerance

выдерживать/выдержать 'to stand, tolerate'

ВНносить/винести 'to stand, tolerate'

допускать/допустить 'to allow'

признавать/признать 'to recognize as valid'

төрпеть 'to stand, tolerate'

4) verbs of provision and acquisition

вөзти, возить 'to carry by means of transportation'

давать/дать 'to give'

доставлять/доставить 'to provide'

отдавать/отдать 'to give back'

передавать/передать 'to relay, pass'

получать/получить 'to receive'

приносить/принести 'to bring'

II. individuating verbs

гнуть/согнуть 'to bend'

задевать/задеть 'to wound, offend'

извивать/извить 'to twist'

изменять/изменить 'to change'

искупать/искупить 'to redeem'

хомхать 'to crumple'

менять 'to change' 
нарушать/нарушить 'to violate' обихать/обидеть 'to insult' оглушать/оглушить 'to deafen' ослеплять/ослепить 'to blind' останавливать/остановить 'to stop' передельвать/переделать 'to alter, do anew' повышать/повысить 'to raise' in the context of повушать/повысить голос 'to raise the voice' поднимать/поднять (в атаку) in the sense of побуждать/побудить 'to incite' подчерхивать 'to emphasize' полонять/полонить 'to take captive' посрамлять/посрамить 'to disgrace' прерывать/прервать 'to interrupt' проваливать/провалить 'to ruin, spoil' разбивать/разбить 'to break' разрушать/разрушить 'to destroy' ремонтировать/отремовтировать 'to repair' сжигать/сжечь 'to burn' сламывать/сломить 'to smash' смущать/смутить 'to embarass' смягчать/смягчить 'to soften' снижать/снизить 'to lower' топить 'to heat' 
Appendix 2 to Part I: Neutral Verbs

брать/взять 'to take'

бросать/бросить 'to throw away, abandon'

B бить 'to hammer in'

вдевать/вдеть 'to put into'

втихать/воткнуть 'to stick into'

есть/съестb 'to eat'

забывать/забыть 'to forget'

зарыть 'to bury'

захлопвуть 'to slam'

говчать/ховчить 'to finish'

любить 'to like'

oпnсквать/описать 'to describe'

осматривать/осмотреть 'to examine, inspect'

отбирать/отобрать 'to take away'

отводать/отвести 'to avert'

отхрывать/отхрыть 'to open, reveal'

отнимать/отнять 'to take away'

переменять/переменить 'to switch'

поднимать/поднять 'to raise'

позвать 'to summon'

показивать/показать 'to show'

преуменшать/преуменшить 'to underestimate'

приветствовать 'to welcome' 
принимать/принять 'to accept'

проиграть 'to lose (a competition)'

пропускать/пропустить 'to miss'

проявлять/проявить 'to show, manifest'

разбирать/разобрать 'to sort out'

pвats 'to take off

свимать/снять 'to take off

сохранять/сохранить 'to preserve'

срывать/сорвать 'to rip off

cy ARTb 'to judge'

терать/потерать 'to lose (something)'

Увосить/Увеств 'to take away on foot'

читать/прочитать 'to read'

ввлять/явить 'to show, display' 


\section{Part LI. Predicate Adjectives}

\section{Chapter 4. Preliminaries}

\section{1. Introduction}

Predicate nominals ( $\mathrm{PN}$ 's) may occur in different forms in Russian: nouns may appear either in the nominative or in the instrumental case; adjectives may appear in the long-form nominative case, in the long-form instrumental case, or in the short form. Although various works offer different conclusions and observations, many of them, just like the literature on the genitive of negation, seem to make statements which suggest tension between the influence of context and the influence of clause-level parameters. Possible connections between variation in PN forms and context can be found in discussions about the effect of parameters related to evidentiality, temporal-aspectual restrictions, and referentiality of the subject NP on the PN form selection.

Findings by Nichols (1981:163) indicate that evidentiality, or the speaker's evaluation of the validity of the given property, affects the use of PN forms. According to her findings, the nominative form is said to present "a scene as witnessed by the speaker or writer and also as seen from the hearer's or reader's perspective" (Nichols 1981:163). Short-form adjectives can imply the speaker's subjective judgments and evaluations (Isaćenko 1958:148-149). Since perspectives and points of view are not marked by any overt presence of surface morphosyntactic devices 
in Russian, it is possible that context is in part responsible for restricting the validity of the property to a particular perspective.

Another point made in a number of works and commensurate with the connection between form selection and context has to do with tense and aspect. Temporal-aspectual restrictions are said to be correlated with the use of the instrumental case (Vinogradov et al. 1960:464, Gustavsson 1976:329, Nichols 1981:154-157); more specifically, covert tense categories (the pluperfect, past iterative, and past habitual) and implicit change of state are said to trigger the instrumental case. Mrázek (1964:223-224) claims that the instrumental case is marked for resultative actualization of a property as opposed to the unmarked nominative case. Shortform adjectives are also likely to present temporally restricted states (Peškovskij 1914/1956:85, Vinogradov et al. 1960:450, Bauer et al. 1966:229-230, Ś vedova et al. 1980:295). Since restrictions of this type are not overtly expressed by the verb бить 'to be', such readings of predicate nominal clauses might be generated by contextual references to other properties of the entity in other possible temporal-aspectual domains.

A connection between context and form selection of PN's also seems apparent in observations related to referentiality of the subject referent. Such observations are made by Isačenko and Babby. According to Isačenko (1965:195-196), example (1), with a long-form nominative case, is equivalent to (2).

(1) Хитаискии язык очень трудный. 
'[lit] The Chinese language is very difficult.'

(2) Ватаиския язых очень труднин (яэых).

'The Chinese language is (a) very difficult (language [=one]).' In other words, (1) reports that Chinese belongs to a set of difficult languages. Similar observations are also made by Šaxmatov (1925, 1927/1941:192), who observes that the function of predicate adjectives of the type in (1) is similar to modification (определевие). Similarly, according to Babby's analysis (1975:203), example (1) reports that Chinese is characterized as being difficult relative to other languages. Such interaction between referentiality of the subject NP and the use of the longform nominative case is shown by Nichols (1981:303-305) as well. It is possible that such a set-membership interpretation is generated by context where sets and other members are mentioned or implied.

A more direct link between context and form selection is indicated by Gustavsson (1976:309). He states that the long-form nominative case is frequent when the subject of the sentence is previously unknown, while the short-form adjective is frequent when the subject is previously known or given.

These observations about the interaction between selection of PN forms and evidentiality, temporal-aspectual restrictions, and referentiality of the subject NP suggest that context at least in part might contribute to the generation of interpretations of the 
subject NP and the property, and therefore might have some impact on selection of PN-forms.

There are, however, observations which indicate that use of PN forms may also be determined rather automatically by clauselevel parameters. The presence of complements to predicate adjectives strongly favors the short form (Vinogradov et al. 1960:450, Gustavsson 1976:178-179, śvedova et al. 1980:295). Nichols (1981:161-162) observes that negation and overt modal categories such as imperative, conditional, and counterfactual clauses favor the instrumental case, in addition to the future tense. Inherent referential properties of the subject NP are said to affect selection of predicate adjective forms; thus, subjects without adjuncts favor the long-form nominative case, while those with adjuncts favor the short form and/or the long-form instrumental case (Gustavsson 1976:282-304).

In sum, previous investigations suggest that both context and clause-level parameters participate in selection of predicate nominal forms. Previous works which point out the correlation between different PN forms and evidentiality, tense-aspect, and referentiality also suggest that clauses with different predicate nominal forms may have different discourse functions. I will address these issues in my discussion of predicate adjectives (PA's). 1 


\section{2. The Data Base}

1457 examples were collected from 11 memoiristic texts from the twentieth century. Clauses with PA's -- the short form (AS), the long-form nominative case (AN), and the long-form instrumental case (AI) -- and overt forms of $6 \mathrm{ST} \mathrm{T}_{\mathrm{b}}$ 'to be' were counted as examples; this means that the corpus consists of examples with the past-tense forms and future-tense forms of бить. ${ }^{2}$ Consequently examples in the present tense, which never allow AI, fall outside the scope of this investigation.

Below is the list of the types of examples which were treated separately and/or excluded from the corpus. A description of each type of example follows the table.

\section{Table 1. Excluded Examples and Examples Treated Separately}

I. examples which were treated separately

1) demonstrative adjectives and headless adjectives in the neuter singular

II. excluded examples

1) adjectives with specific suffixes

2) substantivized adjectives

3) AS-only adjectives

4) comparative and superlative degree forms

5) pronominal adjectives

6) participles

7) subordinate clauses as subjects 


\subsection{Demonstrative Adjectives and Headless Adjectives in the}

\section{Neuter Singular}

I will deal primarily with examples with pronominal, proper, modified common, and unmodified common nouns with overt head nouns as their subjects. PA form selection in examples with demonstrative adjectives and adjectives in the neuter singular NP's without head nouns (e.g., это 'this', Bcë 'everything', тo 'that', что 'what/which/that', главвое 'the important thing') is tested quantitatively, but it will not be discussed in depth here; these subject NP's can be considered as NP's without gender and number specifications (Corbett 1979:8-12, 19-21), and their agreement patterns can be expected to differ from those with other subject NP's.

\section{2. 2. Adjectives with Specific Suffixes}

It is often difficult to determine whether a given adjective is able to form AS. In this paper I excluded those adjectives which, for morphological reasons, clearly do not have AS: those with specific suffixes, e.g. $\{s k\},\{e n ' k\},\{s\}, \mid$ ov $\}$ (сна hnepcxuth pertaining to sniper', маленьхия 'small', плохенькин 'baddish', большон 'big', свинщовин 'lead').

\section{2, 3. Substantivized Adjectives}

When the adjective was obviously substantivized, it was not included in the corpus.

(3) [...] он был тот же слепонAN. (Kon. 165)

' $[. .$.$] he was that same blind manAN.'$ 
In the example above the adjective is modified by a demonstrative adjective $\mathrm{T} O \mathrm{~T}$ 'that'; this is an indication of a substantivized adjective.

4. 2. 4. AS-only Adjectives

Those adjectives that appear only in AS in the following meanings were excluded. Below is the list of such adjectives from my corpus.

велик 'too big'

долxer 'should'

мал 'too small'

вамерев 'intend to'

pas 'glad'
ГОтов 'ready'

ХИВ-вдОрОВ 'safe and sound'

молод 'too young'

прав 'right'

cTap 'too old'

\section{2. 5. Comparative and Superlative Degree Forms}

I will only discuss constructions with the positive degree forms, since the occurrences of AS, AN, and AI among comparative and superlative degree forms are more restricted. Not all comparative forms can appear in all of the three forms; this opposition is irrelevant to synthetic comparative forms. Likewise, not all superlative forms appear in all of the three forms; superlative synthetic forms rarely appear in AS, and superlative analytical forms never appear in AS.

\section{2. 6. Pronominal Adjectives}

Relative and interrogative pronouns and pronominal words are excluded when they are used in isolation; they inquire about properties of the entity, or refer to previously mentioned 
properties, but, unlike other adjectives, do not by themselves present new properties regarding the entity. The following is the list of relative-interrogative pronouns and pronominal words excluded from my corpus.

$\begin{array}{llll}\text { xaxoB } & \text { 'of what sort' } & \text { TaxoB } & \text { 'of such sort' } \\ \text { xaxoBot } & \text { 'which' } & \text { TaxoBot } & \text { 'such' } \\ \text { xaxon } & \text { 'what' } & \text { Taxon } & \text { 'such' } \\ \text { xax } & \text { 'how' } & \text { Tax } & \text { 'so' }\end{array}$

\section{2. 7. Participles}

Participles differ from adjectives in that they are said to form a category marked for "verbality" in relation to adjectives (Jakobson 1932/71). Because of this property, they were excluded from the corpus unless one of the following conditions indicating adjectivalization was met: they had ne- at the beginning (e.g., H подрахаем 'inimitable'); or -nn- appeared in the nonmasculine-singular short forms (e.g., feminine singular short form изусканна, neuter singular short form изысканно, plural short form изысканкы 'refined').

\section{2. 8. Subordinate Clauses as Subjects}

Subordinate clauses, which one could argue are the subjects of the PA's (such as below), were excluded. Such subjects do not have gender or number.

(4) Удержать его било невозможноАS? (Kon. 24) 
'Keeping him back was impossibleAS?.'

(5) Вам известноАS? также, что после этого заявления поведение [...] ни в чем не изменилось. (В. 59)

'It is knownAS? to you also that after this statement the behavior [...] did not change one bit.'

\section{3. Quantitative Results}

\section{3.1. Quantitatively Documented Parameters}

The following is the list of quantitatively documented parameters.

\section{Table 2. Quantitatively Documented Parameters}

1. property of the subject NP

1) referential uniqueness of the subject NP

II. property of the predicate

1) presence of nominal and infinitival complements to the PA

2) future-tense forms of $6 \mathrm{HTb}$ 'to be'

3) past-tense forms of $6 \mathrm{WT}$

III. property of the clause

1) counterfactual and concessive clauses

The corpus was first divided into two groups: those with and without complements. Each group was then subdivided into three subgroups: counterfactual and concessive clauses, future tense, 
and past tense. By counterfactual clauses I mean those constructions with the past tense forms of $\sigma \mathrm{wTb}$ and $\sigma \mathrm{W}$, and those with the past tense forms of $\sigma_{\mathrm{K}} \mathrm{T}_{\mathrm{b}}$ and $\mathrm{Y}_{\mathrm{T}} \circ \sigma_{\mathrm{U}}$ 'so that'. By concessive clauses I specifically mean those clauses with $\mathrm{KaK}$ 'how' and $\mathrm{xax} \cap \mathrm{H}$ 'wat kind of with $\mathrm{B} \mathrm{n}$ '...ever'.

As for referential uniqueness, the parameter measures the likelihood of the subject NP to refer to unique individuals and entities. NP's can be ordered hierarchically in terms of this parameter as follows:

\section{Figure 1. Referential Uniqueness}

referentially more unique (-.......................> less unique

pronominal-proper $\geq$ modified common $\geq$ unmodified common

Pronouns and proper nouns are most likely to refer to individuals and entities that both the speaker and the addressee are able to identify; in other words, both the speaker and the addressec possess sufficient information about the individual or entity to pinpoint him-her-it out of the set. Unmodified common nouns, on the contrary, do not signal any property about the individual or entity; they can equally well refer to a generic category or a member .- arbitrary or specific -- of the set of comparable entities. These NP's are least likely to refer to unique individuals and entities. As for modified common NP's, they are different from unmodified nouns in that they signal at least one 
property attributed to the entity or individual, and thus are more likely to refer to specific entities or individuals. In other words, the amount of information which is assumed to be shared by the speaker and the addressee is likely to be the largest among pronominal and proper subjects and to be the smallest among unmodified common noun subjects.

As previously mentioned, examples with demonstrative or headless adjective neuter singular subject NP's are separated from the others.

The following table illustrates the way in which the examples were subdivided: 


\section{Table 3. The Corpus}

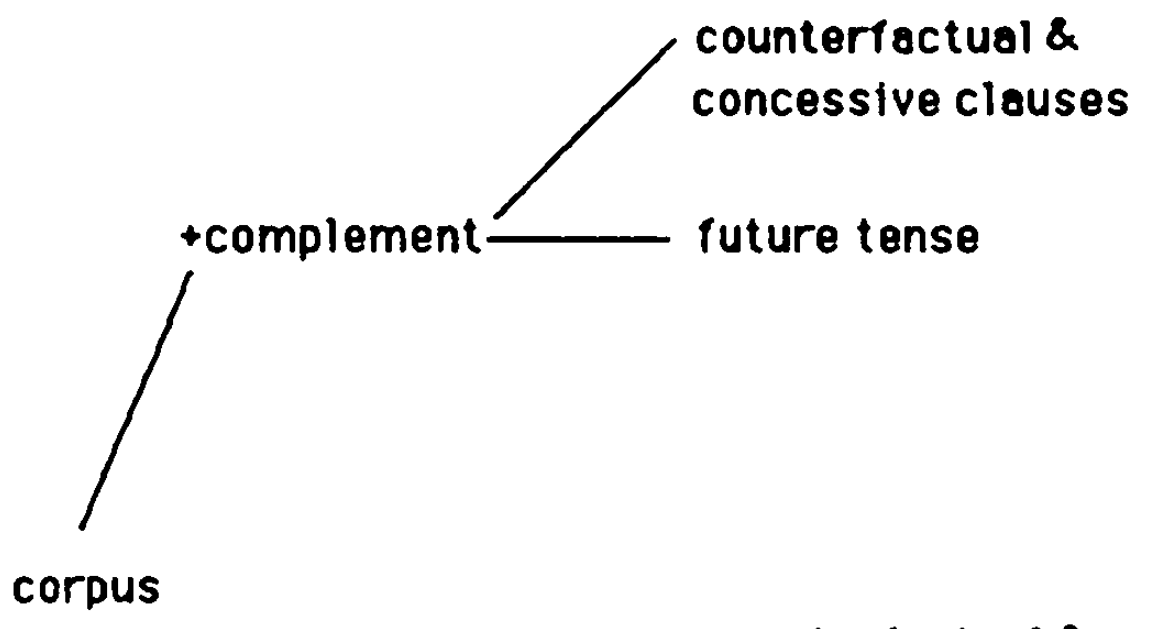

Each group of examples from (1) to (6) was tested for the degree of referential uniqueness of the subject NP.

In the following section, I will present the quantitative results of these tests.

\subsubsection{Frequencies of $A N$. AS, and $A I$}

The tables below show frequencies of $A N, A S$, and $A I$ in different environments. Discussion follows the tables. 
Table 4. Frequencies of PA-forms in the Presence of Complements

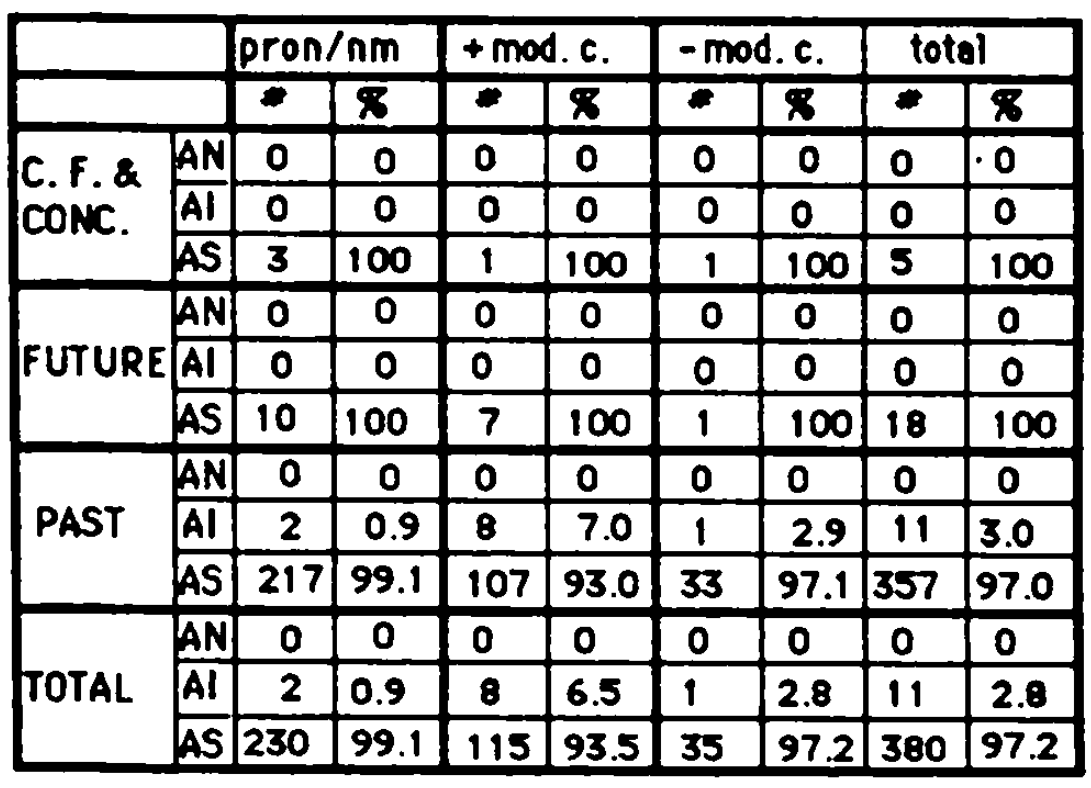

\begin{tabular}{|c|c|}
\hline \multicolumn{2}{|c|}{ éto etc. } \\
\hline- & \multicolumn{1}{|c|}{} \\
\hline- & - \\
\hline- & - \\
\hline- & - \\
\hline- & - \\
\hline- & - \\
\hline- & - \\
\hline 0 & 0 \\
\hline 1 & 3.6 \\
\hline 27 & 96.4 \\
\hline 0 & 0 \\
\hline 1 & 3.6 \\
\hline 27 & 96.4 \\
\hline
\end{tabular}

Table 5. Frequencies of PA-forms in the Absence of Complements

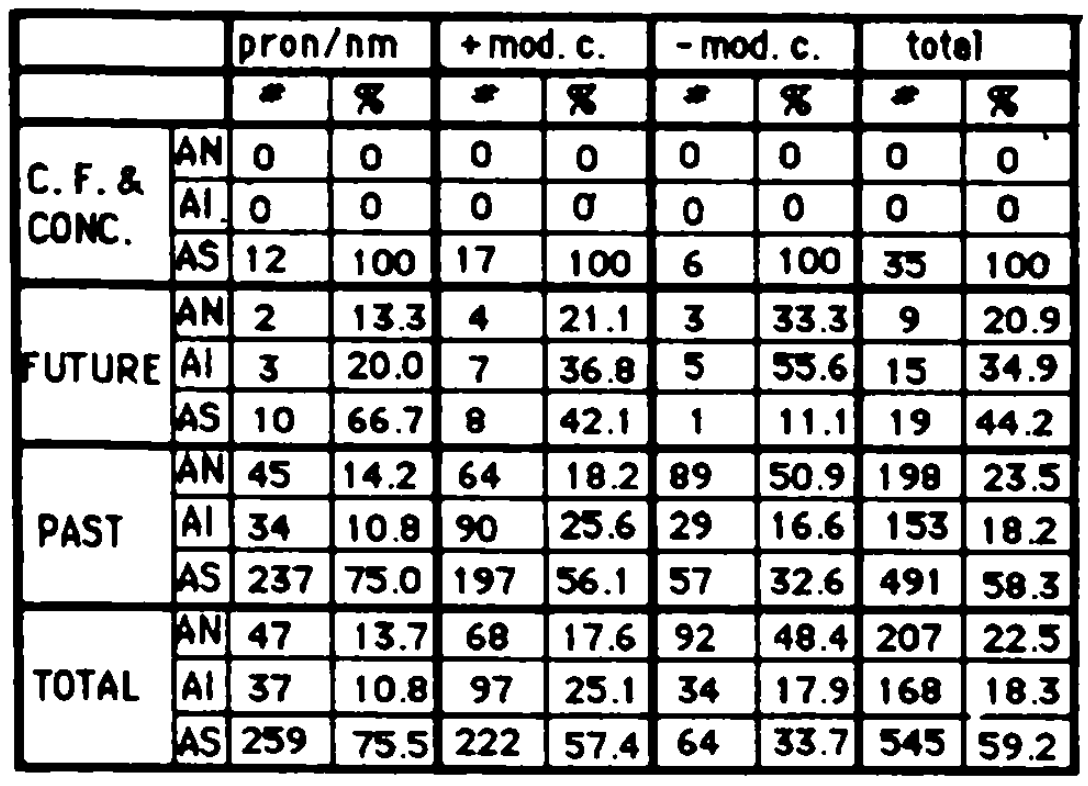

\begin{tabular}{|c|c|}
\hline \multicolumn{2}{|c|}{ ito etc. } \\
\hline 0 & $\bar{x}$ \\
\hline 0 & 0 \\
\hline 0 & 0 \\
\hline 3 & 100 \\
\hline 0 & 0 \\
\hline 2 & 40.0 \\
\hline 3 & 60.0 \\
\hline 3 & 3.6 \\
\hline 7 & 8.3 \\
\hline 74 & 88.1 \\
\hline 3 & 3.4 \\
\hline 9 & 10.1 \\
\hline 77 & 86.5 \\
\hline
\end{tabular}

The numbers in some of the cells in Table 4 are small, but overall they suggest that AS is nearly obligatory in the presence 
of complements to predicate adjectives. In the presence of complements, the total frequency of AS in examples with pronominal-proper, modified common, and unmodified common subject NP's is $97.2 \%$. The frequencies of AS in examples in the future and past tenses indicate that AS is selected regardless of referential uniqueness of the subject NP and of properties of the verb. The total frequencies of $A S$ in both the future and the past tenses are $100 \%$ or nearly $100 \%$.

In the absence of complements, form selection interacts with properties of the clause, the verb, and the subject NP to varying degrees. AS is automatically selected in counterfactual and concessive constructions; in these constructions referential uniqueness of subject NP's does not correlate with form selection. 3

In the future and past tenses (in the absence of complements), form selection is not automatic. Here, properties of the verb and the subject NP interact with form selection. The total frequency of Al in the future tense $(34.9 \%)$ is significantly higher than in the past tense (18.2\%); the likelihood of AI appearing in the future is higher than in the past tense by nearly two times (1.9 times). The difference between the total frequencies of $A S$ in the two tenses, in contrast, cannot be considered significant; AS is only 1.3 times more likely to appear in the past tense than in the future tense. As for AN, its total frequency in the past tense is practically identical to that in the future tense: $A I$ is 1.1 times more likely in the past tense than in the future tense. 
Within the future tense, the frequency of $A I$ is in inverse relationship to the degree of referential uniqueness; it is $20.0 \%$ in examples with pronominal and proper subject NP's, 36.8\% in examples with modified common subject NP's, and $55.6 \%$ in examples with unmodified common subject NP's; thus, AI is 2.8 times more likely in examples with subject NP's of the lowest referential uniqueness than in those with subject NP's of the highest referential uniqueness.

The frequency of AN in the future tense is also inversely related to the degree of referential uniqueness. The values are $13.3 \%, 21.1 \%$, and $33.3 \%$ in examples with pronominal and proper subject NP's, modified common subject NP's, and unmodified common subject NP's, respectively. AN is thus 2.5 times more likely to appear with subject NP's of the lowest referential uniqueness than with those of the highest referential uniqueness.

The frequency of AS, in contrast, is directly proportional to referential uniqueness in the future tense: it is equal to $11.1 \%$, $42.1 \%$, and $66.7 \%$ in examples with unmodified common subject NP's, with modified common subject NP's, and with pronominal and proper subject NP's, respectively. AS is thus 6.0 times more likely to appear in examples with subject NP's of the highest referential uniqueness than in examples with subject NP's of the lowest referential uniqueness.

In the past tense, $A S$ and $A N$ correlate in the same way as in the future tense with degrees of referential uniqueness of the 
subject NP. The frequency of AS is directly proportional to referential uniqueness. AS is 2.3 times more likely in examples with pronominal and proper subject NP's than in examples with unmodified common subject NP's. The frequency of $A N$ is in inverse relationship to referential uniqueness. $\mathrm{AN}$ is 3.6 times more likely in examples with unmodified common subject NP's than in examples with pronominal and proper subject NP's.

The behavior of $\mathrm{AI}$ in the past tense is different from that in the future tense. Al correlates inversely with referential uniqueness in the future tense, but there is no correlation in the past tense; the frequency of $\mathrm{AI}$ is $16.6 \%$ in the examples with unmodified common subject NP's, $25.6 \%$ in examples with modified common subject NP's, and $10.8 \%$ in the examples with pronominal and proper subject NP's. In other words, unlike AS and AN, Al does not correlate consistently with referential uniqueness in the future and the past tenses.

Tables 4 and 5 thus indicate that $A N$ and $A S$ might be directly opposed to each other, but Al might be an intermediate type between AN and AS. AN does not occur when AS is automatically selected (in counterfactual and concessive clauses, and clauses with complements). In other environments AN and AS consistently correlate with referential uniqueness in opposite ways; the former is in inverse relationship to referential uniqueness, while the latter is directly proportional to it. 
As for $\mathrm{Al}$, it does not behave as consistently in relation to the parameters to which $A N$ and $A S$ are sensitive. AI behaves somewhat differently from AS in that it, like AN, is rare in clauses with complements, and concessive and counterfactual clauses. AI, however, does not behave exactly like AN either; it does not correlate with referential uniqueness consistently. In the past tense, AI does not correlate either directly or inversely proportionally with referential uniqueness; in fact, the frequency is highest in the middle of the scale. Furthermore, AI differs from both AS and AN in that AI is favored in the future tense. The relationship between the frequencies of PA-forms and the four parameters -- the presence of complement, concessive and counterfactual clauses, referential uniqueness, and the future tense -- can be summarized as below. Here, " + " indicates that the given form is favored, "-" indicates that it is disfavored, and " $\emptyset$ " indicates absence of clear sensitivity to the parameter.

\section{Table 6. Correlation between Erequencies of PA forms and} the Clause-level Parameters
complement
c. f.\&conc. ref. unia. fulure

$\begin{array}{lllll}\text { AS } & + & + & + & \emptyset \\ \text { AN } & - & - & - & \emptyset \\ \text { A I } & - & - & \emptyset & +\end{array}$


The table above indicates that $\mathrm{AS}$ and $\mathrm{AN}$ consistently behave in two opposite ways, while AI does not.

The results from Tables 4 and 5 also indicate that the degree of automaticity in form selection of PA's varies in different environments. ${ }^{4} \mathrm{AS}$ is nearly obligatory in counterfactual and concessive clauses, and in clauses with complements. Although the number of examples in counterfactual and concessive clauses is small in Table 4, the strength of this parameter is clearly indicated by the high frequency of AS under this parameter in Table 5. Counterfactual and concessive constructions and clauses with complements can thus be considered as "strong" environments for AS.

In the past tense (in the absence of complements), AS is the most favored form in clauses with pronominal-proper subject NP's and with modified common subject NP's; these clauses can be considered "weak" environments favoring AS. In contrast, AN is the most favored in clauses with unmodified common subject NP's; such clauses can thus be considered to represent a weak environment favoring AN.

In the future tense, AS is the most favored form in clauses with pronominal and proper subject NP's; this is then a weak environment favoring AS. Clauses with unmodified common subject NP's favor AI, and is thus considered to represent a weak environment favoring $\mathrm{AI}$. In contrast, $\mathrm{AI}$ and $\mathrm{AS}$ are nearly equally possible in clauses with modified common subject NP's; in 
this environment, form selection of PA forms is the least automatic.

The differences in strength among the environments can be represented graphically in Figures 2 and 3 below. Here, the dark solid zones represent strong environments. The darkness of the patterned zones below indicates the degree to which the given form is favored; when more than one zone with an identical pattern line up. form selection in that environment is considered the least automatic.

$$
80.0<\%
$$

Fing $66.6<R<80.0$

$33.3<\pi<66.6$

$20.0<8<33.3$

$\square \leq 20.0$

T? result not cleor

(total number of examples less than 6)

Eigure 2. Strong and Weak Environments with Complements \begin{tabular}{|l|l|l|l|}
\hline & $p r n / n m$ & $+\bmod . c$. & $-\bmod . c$. \\
\hline
\end{tabular}

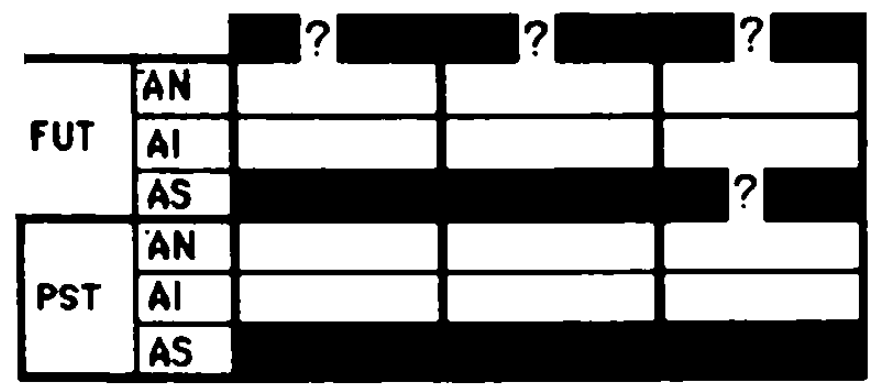


Eigure 3. Strong and Weak Environments without Complements

\begin{tabular}{|l|l|l|l|l|}
\hline \multicolumn{2}{|c|}{} & prn $/ n m$ & $+\bmod . c$. & $-\bmod . c$ \\
\hline c. f. & AN & & & \\
\cline { 2 - 5 }$\&$ & Al & & & \\
\hline
\end{tabular}

In the subsequent sections I will discuss the properties of AS-, AN-, and AI-clauses and the form selection process of PA's. Since AS and AN seem to be in a direct opposition, I will first compare examples with these two forms, and then compare AI-clauses with AS- and AN-clauses. I will limit my discussion to clauses with pronominal-proper, modified common, and unmodified common subject NP's. 
Chapter 5. AS- and AN-clauses

Discussion of differences between AS- and AN-clauses will be presented in three sections. First I will discuss examples in the environments triggering AS almost automatically, second those in the environments favoring $A S$ and those in the environments favoring AN, and third those in the environments which favor neither AS nor AN. The list below defines these environments.

\section{Table 7. AS-AN Form Selection in Various Environments}

I. strong environments triggering AS

1) concessive and counterfactual clauses

2) clauses with complements

II. weak environments favoring AS or AN

1) weak environments favoring AS

a) clauses with pronominal and proper subject NP's in the past and future tenses

b) clauses with modified common subject NP's in the past tense

2) weak environment favoring AN

a) clauses with unmodified common subject NP's in the past tense

III. other environments

1) clauses with modified and unmodified common subject NP's in the future tense 


\section{1. Strong Environments Triggering AS}

The parameters triggering AS all overtly indicate some sort of restriction on the value of the given property. This is illustrated by the examples below.

\section{1. 1. Counterfactual and Concessive Clauses}

Counterfactual clauses restrict the degree to which the property holds in the hypothetical world. In the example below the property ('being unfair') is presented as valid for the individual in the given world to the extent that the individual is fair in what the speaker considers to be the real world.

(6) Однако я била бы решительно несправедливаAS, если бы видела в Зубове тольхо эти бесспорно дорогие хачества артиста. (క. 315)

'However, I would be definitely unfairAS if I saw in Zubov only these indisputably precious qualities of an actor.'

Concessive clauses also necessarily subject the property to restrictions. They represent each of various possible hypothetical worlds in which the property may hold to a specific degree, as in the following example:

(7) Мне стало ясно, что хах бы сильноАS ни было перехивание в момент спектакля, оно дондет до зрителя со всен полнотон лишь в том случае, если кахдая деталь роли тщательно проработана и усвоена со стороны техническои . (Ја. 75) 
'It became clear to me that, no matter how strongAS the feeling is at the moment of performance, it reaches the audience with all its fullness, only provided that each detail of the role be thoroughly worked on and mastered on the technical end.'

In the example above the speaker acknowledges that the feeling may be strong to different degrees at various hypothetical moments of performance. In other words, the clause reports a possibility that the property may hold to a different degree in each hypothetical moment of performance. 5

The examples above indicate that concessive and counterfactual constructions inherently report that the given property might have different values in different worlds.

\subsubsection{Clauses with Complements}

Complements restrict the property presented by the given PA in terms of individuals and entities. When the PA is so restricted, the validity of the PA is guaranteed only for a specific individual or entity. These clauses thus automatically allow the interpretation that the PA might not hold or might hold to different degrees if restricted to other individuals or entities. Some examples follow.

(8) Относился х неи по-дружесхи, и она была со мнон приветлива AS. (Rb. 247)

I treated her in a friendly manner, and she was cordialA S with me.' 
(9) Уезд был богатAS скотом, [...] (Rb. 10)

'The district was richAS in cattle, [...]'

The first example above allows an interpretation that the woman might not have been very friendly with others; and the second example can be interpreted as 'the district was rich in cattle, but might not have been as equally rich in other respects'.

When the PA is restricted by an infinitive, validity of the PA is guaranteed only for that particular action, as in the following example.

(10) Я думаю, в эту мивуту Иосиф был способенАS убить мою мать, [...] (Rb. 60)

'I think, at this moment Iosif was capable of killing my mother, [...]'

The example above yields an interpretation that the property might hold to different degrees or might not hold at all when restricted by other types of actions. This example, again, reports a restriction on the value of the given property.

\section{1. 3. Summary}

Clearly the parameters which select AS almost automatically share a common property of reporting some kind of restriction on the value of the property presented by the PA. It might then be the case that AS-clauses in general report such restrictions; in the next section I will argue that this hypothesis is consistent with the correlation between high referential uniqueness and AS. 


\section{2. Weak Environments Favoring AS or AN}

AS is frequent among examples with referentially unique subject NP's. A referentially unique NP is likely to refer to entities and individuals known to both the speaker and the addressee. What this means is that the speaker and the addressee have sufficient information to differentiate the given entity out of a set. We have observed that the strong environments triggering AS report a restriction on the value of the given property which holds of the entity. These environments then allow the interpretation that the property may hold for the same entity to different degrees in other possible domains; in other words, the strong environments triggering AS are likely to imply the existence of other possible predications for the entity and consequently are likely to present the entity as unique. The examples in the present section will demonstrate that the correlation between referential uniqueness and AS- and AN-clauses not only confirms the property of AS-clauses to focus on restrictions on the property. but also provides further clarification of the relationship between AS- and AN-clauses.

5. 2. 1. Clauses with Pronominal and Proper Subject NP's in the Past and Future Tenses

In clauses with pronominal and proper subject NP's, AS tends to occur, but AN is not excluded. What are the differences between the clauses with expected AS-forms and those with the 
somewhat unexpected AN-forms? Let us look at some of the examples.

The three examples below have the same adjective cпохонин 'calm' and proper names as their subjects.

(11) [...] и хотв с виду Лева был спокоенаS и рассудителен AS, я видел, что он напряжен, как струна, я его хорошо знал, хах ни говорите, родной брат. (Rb. 112)

'[...] and although by appearance Leva was calmAS and sensibleAS, I noticed that he was taut like a string, I knew him well, whatever you say, [...] he is my own brother.'

(12) [...] Артеньев долохил [...] о своих сообрахениях:

Тральщихи -.. прнзнах нехорошин... Фон Киюпфер был у Анвительно спокоен AS и повел себя странно.

-- Вы ошибаетөсь, старлеит,-- сказал он.

-- Простите, я вас не понял. (Pik. 516)

'Arten'ev reported his thoughts:

Mine-sweepers are a bad sign... Von Küpfer was surprisingly calmAS and acted strangely.

"You are wrong, Senior-lieutenant," he said.

"Excuse me, I did not understand."

(13) Знаете, хак это бывает на улице, когда пятеро братьев и все друг за друга, все их боятся, и чем больше их боятся, тем они нахальнее и задиристее. Но я и Лева с ранних лет работали, нам было не до уличных драх и шалостен, Фима был споконнын АN и уравновешенны AN, а 
вот Генрих, чувствуя за собои силу старших братьев, вирос, [...] таким бандитом, что а до сих пор не понимаюо, хах ему не оторвали голову. (Rb. 106)

'You know how it is in the street, when there are five brothers and all protect one another, everybody is afraid of them, and the more people are afraid of them, the more impudent they are and eager to pick a fight. But I and Leva worked from early age, we did not have time for street fights and mischief, Fima was calmAN and levelheaded $A N$, but Henrich, feeling the power of his older brothers behind him, had grown up to be [...] such a bandit that to this very moment I don't understand how he didn't have his head torn off.'

(11) contrasts how Leva appeared on the surface and how he was in reality -- he appeared calm, but actually he was tense. This interpretation is motivated by the weak complement 'by appearance' as well as the context; there are references to the speaker's noticing Leva's tenseness. Likewise, the PA-clause in (12) presents a property of the individual from one participant's (Arten'ev's) perspective. Also, in this text Arten'ev is surprised at von Küpfer's reaction; the latter was exceedingly calm in view of the circumstances. Thus, the value of the property here is restricted to a specific perspective and to a specific circumstance. Each of the contexts in (11) and (12) with AS's, then, is 
interpreted as reporting a restriction on the value of the property in a particular world.

The context in (13) is different from those in the previous two examples; it presents the subject referent as a type. The references to the characteristics of other brothers define a set which can be called "the Raxlenko brothers". With respect to this set, there is no information regarding the individual Fima in the text prior to the PA-clause. The example can thus be rendered as follows: 'Fima was a calm and levelheaded type among the Raxlenko brothers'.

The next pair of examples involves the adjective весель 'cheerful'. The subject NP's in both examples are proper nouns.

(14) -- Вы знаете, мне тохе вначале стало не по себе, хогда увидел военные хорабли. [...] Я подал условнын сигвал и, пока ждал ответа, испытал чувство тревоги, -- сказал Рамон. -- А сенчас, друзья, даванте на продание пообедаем по нашим морским традициям.

Рамон был веселАS, шутил, благодарил за теплые слова в адрес испанскои хоманды. (В. 39)

'You know, I too hadn't got hold of myself at first when I saw the military ships. [...] I gave the pre-arranged signal and, while I waited for the answer, I had a feeling of alarm," Ramon said. "But now, friends, let us dine at parting according to our seamen's traditions." 
Ramon was cheerfulAS, cracked jokes, expressed thanks for the heart-warming words addressed to the Spanish crew.'

(15) У дади и тети Шатровых все было по-иному, [...] Мов дядя [...] торговал ховрами, схатөртями, одеялами. Тетя, Агафья Яховлевна, разумеется, нигде ве слухвла, а только рожала детеи -- [ø] была очень веселаяAN, милая АN, отлично пела руссхие песни. Мух их старшев дочери Оли, $[\ldots]$ бил ярым любителем искусства в нашим главнмм рехиссером. (క. 9)

'At uncle and aunt Satrovs' everything was different, [...] My uncle [...] sold carpets, tablecloths, blankets. My aunt Agafja Jakovlevna, of course, did not work anywhere, but simply bore children -. [she] was very cheerfulAN, sweet $A N$, sang Russian songs excellently. The husband of their oldest daughter, Olja, [...] was a passionate lover of art and our main director.'

The situation presented by the PA-clause in (14) can be understood as a result of the safe arrival of Ramon's ship; he might not have been as cheerful to such a degree or might not have been cheerful at all under different circumstances. Thus, the property can be understood as being restricted to a specific degree in a specific temporal-modal domain.

The text in (15), unlike (14), does not focus on restrictions on the property in the PA-clause. The text in (15) lists and describes 
the speaker's relatives. The PA-clause is part of this text and therefore the property can be understood to present what type of person Agafja Jakovlevna was among the given set of people. It is not clear in this context whether there were other members of the family who were also cheerful.

The following AS-clause in the future tense also reports some restriction on the value of the property in a specific world.

(16) -- Павел Ефимович, позвольте, я буду честенАS... До сих пор я не верил в боеспособность флота. Теперь я преклоняюсь перед его героиством и твердо уповаю, что никако враг нам не страшен: [...] (Pik. 606) 'Pavel Efimovič, excuse me, I will be honest ${ }^{A S}$... Until now I have not believed in the fighting capacity of the fleet. Now I bow down before its heroism and firmly trust that no enemy is frightful for us: $[$....'

The example is followed by statements about the extent to which the speaker will be honest with the addressee on the given occasion; he would be honest with the addressee to such a degree on the given occasion that the addressee would learn the immediately following information. Clearly the AS-clause can be interpreted as restricting the value of the property in a specific temporal-modal domain. 6

\section{2. 2. Modified Common Subject NP's in the Past Tense}

Modified common subject NP's carry some information about the subject referent, and therefore they are more referentially 
unique than unmodified subject NP's. AS is favored in this environment. The examples with expected AS's and with somewhat unexpected AN's indicate that context is involved in form selection. Let us compare the first set of examples involving the adjective коротхив 'short'.

(17) «[... И С кем играла-то!!! Со Стрельскон! [...] Она Удивительно симпатичная старушка. Знмон расскаху, о чем му С нен говорили...»

Разтовор со Стрельскон был коротох AS.

Стрельская, готовясь х внходу, хрестится.

-- Ухасно волнуюсь перед спектаклөм! [...] И төбө нухно волноваться! И мне! До самон смерти надо волноваться! (క̆. 57)

'"[...] And with whom did I perform!!! With Strel'skaja! [...] She is a surprisingly nice old woman. I will tell you in winter what I talked about with her..."

The conversation with Strel'skaja was short ${ }^{A S}$.

Strel'skaja, preparing for the entrance, crosses herself.

"I am terribly worried before a performance! [...] You also need to worry! And so do I! It is necessary to worry until one's death!'

(18) Первое письмо Павла было из читы [...]. Он писал, что ждет назначения, [...] и письмо его было длинным от ничегонеделания. Второе письмо было короткоеАN, 
напечатанное на мащинке и только подписанное от руки.

[...]. (S. 163)

'Pavel's first letter was from Čita [...]. He wrote that he was waiting for an assignment, $[\ldots]$ and his letter was long from idleness. The second letter was short $\mathrm{AN}$, written on a typewriter and just signed by his hand. [...]'

The text in (17) is about a conversation which the speaker had with Strel'skaja, a famous actress. The text following the PAclause illustrates the degree to which the property held, yielding the following reading of the PA-clause: 'the conversation was short to the extent that the whole thing can be presented in exactly the following quotes'. Thus, the PA-clause restricts the validity of the given property to a specific degree.

The AN-clause in (18) is similar to the AS-clause in (17) in that its subject NP is modified. The context, however, presents the entity in a different way. The text preceding the PA-clause refers to the first letter which was long. This presents the second letter (which was short) relative to the first one within a set of Pavel's letters; the former belongs to a subset characterized by being short, while the latter belongs to a subset characterized by being long.

The following pair of examples below involves the adjective храсивы 'beautiful'.

(19) Очень храсивы AS были хостюмы орловских крестьянок. Они друг перед дружкой шеголяли своими нарядами. 
Больтую часть денег, заработанных на подендине, оставляла они владимирду-коробениику, которин с большим хоробом на спине и с аршином в рухах перед празднихами появлялся в деревне, соблазняя храсавны шелховыми лентами, бусами, пуговидами и прочим. (Ryl. 80)

'The costumes of Orlov peasant women were very beautifulAS. They paraded in front of one another their costumes. They gave the larger part of the money earned on day-labor to the peddler from Vladimir, who showed up before festivities in the village with a big box on his back and with a ruler in his hands, tempting the beauties with silk ribbons, beads, buttons, and so forth.'

(20) Аругве белоруси у нас говорили по-русски, одевались по-городскому. Сташенки говорили по-белорусски: [...] одевались они с некоторои примесью белорусскон одехдн: [...] на хеншинах коротхая хофточка со шнуровхон, $[\ldots]$ снняя или храсная юбка, фартух, на голове платок. Женщины в доме Сташенха были очень храсивыеАN, и сам дом был особеннын: [...] и уклад их хизни очень отличался от дедушкнного: [...] Сташенки хили тихо, [...] (Rb. 78)

'Other Belorussians in our area spoke Russian, [and] were dressed like town-dwellers. The Stašenoks spoke Belorussian: [...] And they were dressed with some 
admixture of Belorussian apparel: $[. .$.$] women wore a short$ blouse with a string, [...] a blue or red skirt, an apron, a shawl on the head. The women in the house of Stašenok were very beautifulAN, and the house itself was special: [...] and their life-style was very different from my grandfather's: [...] the Stašenoks lived quietly, [...]'

In (19), the text following the PA-clause presents the intensity with which the peasant women in Orlov cared about their clothing. Thus, the PA-clause focuses on the specific degree to which the property held, and yields the following reading: 'if the women had not been so fussy about their costumes to such a degree, their costumes might have been beautiful to different degrees or might not have been beautiful at all'. The clause can thus be interpreted as reporting the particular value of the property in a particular temporal-modal world.

In contrast, in text (20), everything in this family, including the given group of women can be viewed as being contrasted with women in other Belorussian families. Thus, unlike (19), the focus is not on any specific value of the property, but rather on the women as belonging to a subset characterized by the given property within the more general set of women in Belorussian families.

The last set of examples involves the adjective горячи 'hot, passionate'. 
(21) Все, что она играла, она играла хорошо. Южнже, огромние глаза были горячиАS, молоды AS, но фигура ухе тяхела. Кроме того, совершенствуясь в миниатюрах, Баскахова отвыкла от ролен масштабных. (క. 165) 'Everything she performed, she performed well. Her southern, huge eyes were passionate $A S$, young $A S$, but her figure was already heavy set. Besides, mastering skills in small plays, Baskakova had grown unaccustomed to largescale roles.'

(22) -- Здоро́во! -- сгазал Возырев, приподнимаясь на лохтях и отривая от подушки пилавшую жаром голову. Руха, которую он протянул Артемьеву, била горячаяАN в слабая АN.-- Услышал, что старын знакомй появился на нашем горизонте,--- велел тебя позвать. Сам бы пришел туда, х вам, да малярия одолела. Не в обиде? (S. 117)

"Greetings!" said Kozyrev, getting up on his elbows and tearing his head, which was burning with fever, off the pillow. The hand which he stretched towards Artem'er was hot AN and weakAN. "I heard that my old acquaintance appeared on our horizon, -- I ordered [my subordinates] to bring you. I would have come over myself, to you, but malaria overcame [me]. You are not angry?"

In example (21), the context focuses on the degree to which the given property held on the given occasion. In her performances, 
Baskakova's huge southern eyes were passionate, young to such an extent that the speaker had positive things to say about her performance, but the references to the speaker's dissatisfaction with the actress' performance also suggest that the eyes were not overwhelmingly passionate and young to the extent that they managed to compensate for the other shortcomings in the actress's performance. The context thus focuses on the restriction on the property to a particular degree in a specific temporal-modal world.

(22) is unlike (21) in that there is no indication of focus on the intensity at which the hand was hot and weak. The context thus does not suggest a possibility that the property of the hand might have different values on different occasions. In the absence of any information about the hand other than the PA, the clause presents the given hand as a type of hand which belongs to a set of hands which might have been extended.

Analyses of individual examples indicate that those clauses with AS correlate with referentially unique subject NP's, but the form is selected only if the context reinforces an interpretation focusing on the specific domain in which the property holds to a specific degree. In contrast, AN is selected when the entity is viewed as a type in the given context: AN-clauses therefore can be said to presuppose a general set of entities and to locate the given entity (the subject of the sentence) within a subset inside this general set. The examples from above also indicate that AN- 
clauses at the same time remain ambiguous about whether there are other entities belonging to the subset defined by the PA within the general set.

The semantic property of AN-clauses proposed here is consistent with Šaxmatov 1925, 1927/1941 and Isač enko 1965, in which AN-clauses are said to present the entity as a member of a set of entities characterized by the given property. My analysis is also in agreement with Babby $(1975: 200)$ who states that ANclauses occur when there is an implicit reference to set membership.

Thus, observations from this section not only confirm what we observed in AS-clauses in the strong environments, but also suggest that $A S$ - and AN-clauses might consistently yield two different interpretations of the subject and the property. Let us look at examples in other environments and test this hypothesis.

5. 2. 3. Clauses with Unmodified Common Subject NP's in the Past Tense

Clauses with unmodified common subject NP's tend to cooccur with AN, but AS can also occur. Both the expected $A N-$ and somewhat unexpected AS-forms seem to be motivated by specific interpretations of the clause which were proposed in section 5. 2 . 2. The first set of examples involves the adjective $э \Phi \phi е х т н ы ~$ 'effective, striking'. The subject NP's in both examples are unmodified common NP's, and carry little information about the given entities. 
(23) Я наскоро оделся, выбежал на озаренныи пламенем двор. В усадьбе у нас горели [...] рига и [...] молотильнын саран. Винулся помогать тушить пожар, но хозянха предложила мне идтв $к$ дому и наблюдать необходимы мне для печенегов фон, а хстати в покараулить дом, тах хах там никто не остался. Деиствительно, зрелише было зффектноеАN и хуткоеAN, как раз то, что мне надо. Клочки горяще соломы, висохо поднимаясь в воздух, летели далеко в поле. [...]. (Ryl. 79)

'I got dressed in a hurry, ran out to the courtyard illuminated by the flames. In our farmstead the drying barn and the threshing barn [...] were burning. I rushed to help extinguish the fire, but the landlady suggested that I go to the house and observe the background necessary for me for [painting] the Pečenegs, and at the same time watch the house, since no one had remained there. Indeed, the scene was striking $A N$ and eerie $A N$, just the kind of thing that flit. that which] was necessary for me. Shreds of burning straw, rising high in the air, flew far into the field. [...]'

(24) Колчаху было тогда 43 года -- не только в Россин, но даже за рубежом не было такого молодого хомандуюшего флотом! 
Пресса бурхуазних газет работала ва вего. Адмирал бил зффехтен AS, как герон авантюрвого ромава, и газеты подняли Колчаха на пит славы... Севастополь встретил его оркөстрамд, [...] (Pik. 262)

'Kolčak was then 43 years old -. not only in Russia, but even abroad, there had never been such a young commander of the fleet.

The press of bourgeois newspapers worked on him. The admiral was impressiveAS [=looked good], like a hero of an adventure novel, and the newspapers eulogized Koľak... Sevastopol' met him with orchestras, [...]'

The text preceding the AN-clause in (23) introduces a scene of fire. The speaker wakes up after hearing the noises and sees the drying barn and the threshing barn on fire. The text implies the existence of the scene of fire, but does not provide any information about it. Thus, эффехтное в $\times$ × Txоo 'striking and eerie' are the first properties which specify the given member within the possible scenes of the fire. The given scene, in other words, is presented as a type, as a member belonging to a subset of striking and terrifying fires within a general set of fires.

The context preceding the PA-clause in (24), unlike in (23), does not present the individual as a type. It suggests that the evaluation of the admiral had been exaggerated by the press and that he was not as impressive as people thought he was. 
Furthermore, the text immediately following the PA-clause restricts the validity of the PA with the conjunction $\mathrm{Kax}$; the property holds of the individual as much as it holds of a hero in an adventure novel. All this indicates that in this clause the focus is on the restriction on the value of the property; the property is true only to the extent that the individual is viewed from that particular perspective. Also, in this context, the common noun адмирал 'the admiral' alternates with the proper name Волчах and is used like a pronoun; this indicates that the subject NP is presented as a unique individual.

The following three PA-clauses involve the adjective xopom 'good'. All have unmodified common subject NP's.

(25) В те времена, І... массовое производство еще ве било тах развито и многие предпочитали шить обувь на захаз, (...) Дедушха поставил дело обдуманно, (...) он шил и вил мухсхую обувь и дамскую, от начала до конда, от мерки до готового ботинха. Сам был мастер, и подмастерья были хорошиеАN, и снновья, хотя и не все, тохе потли по canox ноम части, и внуки: [...] (Rb. 49)

'In those days, [...] mass production had not been so developed and many preferred to make shoes on order, $[\ldots]$ Grandfather organized his work with careful consideration, [...] he sewed and wove men's and women's shoes from beginning to end, starting with the measurement and ending with the finished shoe. He himself was a master-craftsman. 
and the apprentices were $\operatorname{good} \mathrm{AN}$, and his sons, although not all of them, also took up shoemaking, as did his grandsons: [...]'

(26) Дирехдия вкпустила храсивую афишу. На афише било написано: «Ударные веqера Борисовскои и Тарахно». Все представления прошли успешно, и сбори били xopomreAN. (T. 163)

The management produced a beautiful poster. On the poster was written: "The Striking Evenings of Borisovskaja and Taraxno". All the presentations went successfully and the box-office returns were $\operatorname{good} A N$.

(27) Перелистан хурналы тех лет - в внqего страшного, опасвого для родины не обнарухвшь. Казалось, что этот мир нерушим...

[...] По Невскому неслись огненние рхсахи, вөривая гомья пушистого снега, а в витрине у Елисеева лехала свехая хлубниха. Последним капризом моды стало дамское манто из шхур леопардов -- и дорого и хутко...

Жнзнь была чертовски хоротаAS! (Pik. S. 6)

Turn the pages of the magazines of those years -. and one cannot find anything frightening, dangerous for the motherland. It seemed that this world was inviolable...

[...] Along Nevskij fiery trotters were running, blowing up lumps of fluffy snow, while in the show-window at Eliseev there were fresh strawberries. A women's coat made 
of leopard's fur became the latest whim of fashion, -- both expensive and eerie...

Life was devilishly goodAS!'

In example (25) the text preceding the PA-clause mentions the speaker's father's shoe store. The text therefore implies the existence of apprentices at this store, but does not present any information about them prior to the PA-clause. The property here is the first available information about them. The AN-clause thus can be interpreted as specifying the subset to which the individuals belong, within the general set of apprentices.

Likewise, the AN-clause in (26) is preceded by a context implying the existence of box-office returns. There is, however, no information about what is special about these particular box-office returns. The AN-clause, then, presents the box-office returns as a type, like (25) -- as belonging to a subset ('good box-office returns') within a more general set of possible box-office returns.

Example (27) is different from the previous two. The text preceding the PA-clause also implies the existence of people's life, but the description of the people's life which was materially rich has already been suggested. Thus, the property presented by AS is not the first property presented to specify the particular member within the set. Furthermore, against the background of the description of the seemingly peaceful state in the imperial Russia when actually the Revolution and the subsequent turmoil were about to take place, the PA-clause can be interpreted as 
implying a contrast between the speaker's perspective and the perspective of the people then -- the danger and uneasiness which were actually present in the life of the people and the seeming peacefulness of the life in Russia. Thus, the validity of the property presented by $A S$ is restricted to a particular perspective.

The examples above indicate that an AN-clause consistently presents the subject referent as belonging to a subset within a larger set -- as a member of a subset characterized by the PA. An AS-clause, in contrast, reports a restriction on the value of the property in a specific world. Thus, these examples support the hypothesis that AN- and AS-clauses yield different types of interpretations of the subject and the property.

The analyses of the examples above also demonstrate that AN is favored in clauses with unmodified common subject NP's which are likely to yield a set-membership interpretation, but that AN is selected when the set membership of the subject referent is reinforced by the context. As for AS, it is selected when context focuses on the restriction on the value of the property in a specific domain. We will now turn to other environments in which neither AN nor AS is favored, and examine whether AN- and AS-clauses yield the respective interpretations I have suggested to this point.

\section{3. Other Environments}

In clauses with modified and unmodified common subject NP's in the future, neither AN nor AS is more favored. The examples 
presented below will demonstrate, however, that general semantic properties of AS- and AN-clauses suggested thus far hold for clauses in these environments as well.

(28) -- [...] Оставь теорню -- гляди в прахтиху: будь я на месте немдев, я бы батареи наши с землеи перемешал, и тогда...

-- Тогда -- да! -- подтвердил Артеньев. --- тогда флот выну хаен првнять бон от немда на Rассарском плесе. И бой этот будет хестохАS. Посуди сам: за хассарами все наши главные маневренные базы. (Pik. 472)

'"[...] Leave theory out of it -- look at the practical side: if I were in the Germans' place, I would confuse our batteries with soil, and then...

"Then -- yes! -- confirmed Arten'ev. -- then the fleet will be forced to accept the battle from the Germans on the Kassar stretch [of river]. And that battle will be fierceAs. Judge for yourself: behind the Kassars there are all our major manœurre bases.'

The AS-clause in (28) is followed by a text indicating the importance of the location of a possible battle. It is also preceded by a text indicating that the location of the battle would be disadvantageous for the Russians; this is supported by the expression вынужден принать бо 'being forced to accept the battle. The speaker thus concludes that the Russians would have to fight off the Germans at any cost, no matter how difficult it 
might be. In this context, then, the AS-clause can be viewed as focusing on the intensity of the battle under the given circumstance. The following AS-clause with unmodified common subject NP's yields a similar interpretation.

(29) Рабочне-путиловры с трудом добились аудненыии Керевского. Они предупредили его, что Путиловскин бастует и забастовка их мохет стать осново для потрясени страви. Потрясения будут гранднозныАS -. ни с чем ранее не сравнимы... Керенскин их не повял, а ведь они огазались пророхами! (Pik. 303)

'The Putilov factory workers managed to see Kerenskij with difficulty. They warned him that the Putilov factory was on strike and that the strike might become the basis for shocks to the country. The shocks will be grandioseAS -. incomparable with anything before... Kerenskij did not understand them, but, in fact they turned out to be prophets!'

The text in (29) is about the workers who came to warn Kerenskij not only of the strike, but of its intensity and its subsequent effects on the rest of the country; the emphasis is on the intensity of the strike is supported by the text но с чем ранеe несравними 'incomparable with anything before'. The PA-clause, then, can be interpreted as restricting the value of the property in a hypothetical world. 
Examples with $A N$ in the future tense yield interpretations different from examples with AS above.

(30) По хаким причинам роль Полины Семеновни осталась за мнон? [...] не знаю, но меня вызвали на хиностудию вторкино. [...] ('́. 306)

Моя Полина Семеновна сама читает газети, она хөвщина вполне грамотная, но она будет похоха на мать начальниха аэропорта. На свон волосу я налоху седую нахладху, общй тов лида будет темнияAN, l...) (క. 308)

'For what reasons Polina Semenovna's role stayed with me? [...] I don't know, but I was summoned to the movie studio for the second time. [...]

My Polina Semenovna reads newspapers by herself, she is a completely literate woman, but she will resemble the mother of the chief of the airport. On my hair I will put a gray hair piece, the general tone of face will be darkAN, [...]'

In (30) the text prior to this paragraph suggests that there had been other potential candidates for the role of Polina Semenovna. Thus, in this case, the speaker is implicitly contrasting her own way to play the role versus other actresses' ways. Since the ANclause is part of the text contrasting the given Polina Semenovna with other possible Polina Semenovnas, the subject of this clause can be interpreted as a member of a set of the tones of P. S.'s face made by actresses in general. The PA-clause thus locates the 
entity within a subset of this general set, and, unlike (28) and (29), does not focus on the intensity at which the property holds of the entity in the given world.

In the following example with an unmodified common subject NP the set-membership interpretation is very clear.

(31) Если декорадии и гостюмы черезмерно архве, они мешают говорить просто. Необходимо едннство всех элементов. Вогда ахтер будет говорить просто, а дехорадия будет яркая АN, она его поглотит. (Ја. 70)

'If sets and costumes are excessively loud, they prevent [actors] from speaking in a simple fashion. Unity of all the elements is necessary. When an actor speaks [lit. will speak] in a simple manner, while the set is [lit. will be] loudAN, it will swallow him up.'

In the text preceding the PA-clause above, the speaker is talking about various stage sets and their interaction with other elements on stage; the PA-clause presents a general statement about the outcome of using a loud stage set when an actor speaks in a simple manner. The subject NP of the PA-clause is thus interpreted as a type: as a member of a subset (characterized as being loud), among all the possible stage sets.

As in examples from sections 5. 2.1 through 5. 2. 2, AS-clauses in this section restrict the validity of the given property; ANclauses, in contrast, present the given entity as a member of a subset characterized by the PA within a more general set. These 
examples also confirm the earlier observations that context participates in invoking these two distinct interpretations and consequently in selection of PA-forms.

In the following section I will make an interim conclusion to the form-selection process of $A S$ and $A N$ and propose semantic representations for AS- and AN-clauses.

\section{4. Properties of $\mathrm{AS}$ - and $\mathrm{AN}$-clauses}

The individual examples given above indicate that an ASclause reports the given world $w_{1}$ in which the property $P$ holds of $x$ to a specific degree $y 1$ as a member of a set of worlds $W$; $W$ may be an open or a closed set of worlds. The figure below shows that $P$ holds of $x$ in worlds $w_{1}, w_{2}, \ldots w_{m}$ to degrees $y 1, y 2, \ldots y m$ respectively. The parentheses indicate that there may exist a world $w_{n-1}$ and $w_{n}$ in which $P$ does not hold at all ( $P$ ). As shown below, there is no clear boundary between the worlds in which the property $P$ holds of $x$ and the worlds in which it does not, since the set $W$ is viewed as forming a continuum of worlds in which $P$ holds to different degrees. 


\section{Eigure 4. Semantics of an AS-clause}

$$
\begin{aligned}
& p^{1 . . . m}(x) w_{1} \ldots m \\
& P \text { yn-1,yn }(x) w_{n-1, n} \\
& =\sim P(x) w_{n-1, n}
\end{aligned}
$$

Since the given predication $\mathrm{Py}^{1} \mathrm{w}_{1}$ may be presented as one of many possible predications which are assumed to exist (Py $\mathbf{l}_{\mathbf{w}_{1}}, \ldots$ $P{ }^{n} w_{n}$ ), the subject referent is likely to be presented as a unique entity about which much information is assumed to be available to the addressee in order for him or her to identify it. The subject NP of an AS-clause is therefore likely to present the subject NP as unique.

As for AN-clauses, individual examples suggest that AN is used when the PA-clause reports that a member $x_{1}$ (of the set $X$ ) belongs to the subset defined by the property $P$. The members $x_{m}$, $x_{n}$ are those of which $P$ does not hold; $x_{2}$ in parentheses indicates that $X$ may also contain members of which $P$ holds. ${ }^{7}$ The clearly marked boundary between $P$ and $\sim P$ indicates that $A N$-clauses do not present the property $P$ as potentially valid to different degrees. 


\section{Biance 5. Semantics of an AN-cinnse}

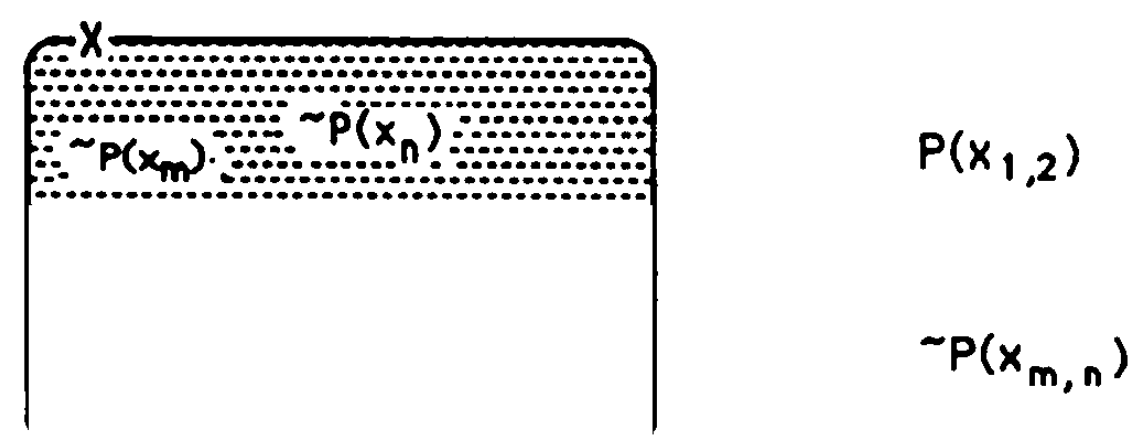

This analysis of the semantic property of AN-clauses is consistent with the observations by Śaxmatov (1925, 27/41), Isačenko (1965), and Babby (1975).

Since AN-clauses do not focus on different values of the property, and report that there may be other members of the set which are characterized by property $P$, the subject referent in ANclauses is less likely to be presented as unique (as distinct from all the other members of the set) than the subject referent in ASclauses.

My analysis of AS-clauses is commensurate with Isač enko and other scholars who claim that AS may imply evaluative judgments and/or temporary states. AS-clauses restrict the value of the property; this restriction may be related to tense or perspective. My analysis, however, differs slightly from the previous works. The previous works state or imply that the difference in referentiality of the subject NP is built into the two PA-forms or the syntactic structures of AS- and AN-clauses. In contrast, I have proposed two basic semantic models for AS- and AN-clauses and 
have claimed that the difference in referentiality of the subject NP results from the difference between these semantic models.

In addition to constructing semantic models for AS- and ANclauses, I have also demonstrated how these properties are generated by context and clause-level parameters in different environments. The data from my corpus suggest that form selection of PA's might be made at different levels. This is illustrated in Figure 6 below. Here, examples with complements nearly automatically select AS; thus, form selection is determined on the predicate level when complements to the PA are present. Concessive and counterfactual clauses select AS as well; when these parameters are present, form selection is thus determined on the level of overt modality. The solid area extending from AS indicates that the above mentioned clause-level parameters override other considerations.

In the absence of these automatic parameters, namely in the past and future tenses, form selection between $A S$ and $A N$ is not automatic; there is a high degree of contextual influence on the interpretation of the PA-clause. This is indicated by dotted areas extending both from AS and from AN. 
Burnte 6. Desrees of Antomsticity in AN-AS form selection

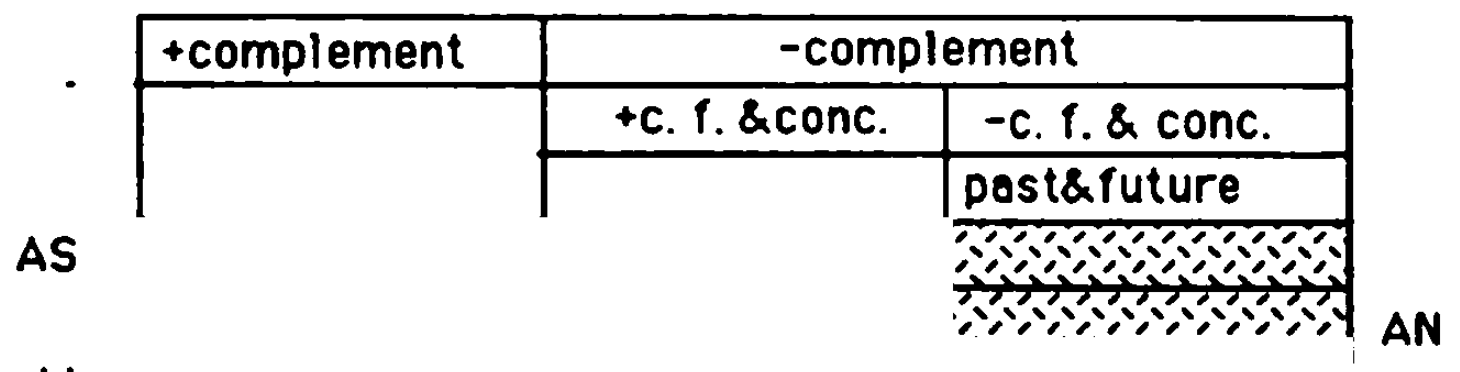

The connection between the referential uniqueness of the entity and the occurrences of $\mathrm{AN}$ and $\mathrm{AS}$ raises another problem: what are discourse functions of AS- and AN-clauses? Unique entities are those entities about which the speaker and the addressee have sufficient information to distinguish them from all the other comparable entities. If an AS-clause is likely to present its subject NP as unique, then it follows that a considerable amount of information about the subject referent is likely to be located in what the speaker considers to be the addressee's preexisting knowledge. This is consistent with Gustavsson's observation (1976:309) that discourse definiteness favors AS. A property presented by AS, then, adds further information to the addressee's knowledge about the already known entity. An ANclause, in contrast, is less likely to present the subject NP as unique. Hence little information about the subject referent of an AN-clause is likely to be located in what the speaker considers to be the addressee's preexisting knowledge than the subject 
referent of an AS-clause.

To recapitulate, the analyses of the quantitative data and the individual examples thus far have further elaborated the descriptions of the semantic properties of $\mathrm{AN}$ - and AS-clauses in some of the literature, have demonstrated that these properties are generated under different degrees of contextual influence, and have proposed the discourse functions which the two types of PAclauses are likely to have. In the following chapter I will examine the status of Al-clauses. 


\section{Chapter 6. Status of Al-clauses}

Previous literature is unclear about the properties of AIclauses relative to AN- and AS-clauses. On the one hand, Al-forms are represented as being in direct opposition only to AN (Babby 1975:154). In other words, PA forms are described in terms of two binary oppositions; long forms vs. short forms constitute the primary opposition, and AN vs. AI the secondary opposition. On the other hand, there are observations that AI, like AS, implies restrictions on the property; this relationship between $\mathrm{AI}$ and temporal or temporal-aspectual-modal restrictions has been pointed out in the literature (Gustavsson 1976:329, Nichols 1981:154-157, 161-162). The data in Tables 4 and 5 are not very clear about the status of AI either, but the relatively high frequency of $\mathrm{AI}$ in the future tense suggests that the semantics of Al-clauses might involve tense, aspect, and modality. In fact, according to Chvany (1975:90), the future forms of the verb 6 к т b may "behave like a perfective, its acquired future meaning being compatible with contexts of perfectives". Also, according to Forsyth (1970:129), the verb бы ть used in the imperfective future can have a function similar to an auxiliary. He observes that the ability of the future tense forms of $6 \mathrm{HTb}$ to express mood is particularly explicit when the speaker "rejects the very idea of the action named," and cites, among others, the following example:

(32) -- Я рабочин, -- говорил Валет... -- За что я тебя буду убивать? Беги! -- 
"I'm a worker," said Valet... "Why should I kill you? Run for it!"' (Forsyth 1970:129)

Here, the sentence reports a contrast between the reality and what the speaker considers to be the addressee's belief. 8

Individual examples with $\mathrm{AI}$ in the environments listed below indicate more specifically that the semantic model for AI-clauses involves two distinct worlds and a semantic primitive similar to one used to describe the perfective aspect in Russian.

\section{Table 8. Occurrence of $\mathrm{AL}$ and Various Environments}

I. weak environment favoring $\mathrm{AI}$

1) clauses with unmodified common subject NP's in the future tense

II. other environments

1) clauses in the future tense with pronominal and proper subject NP's and modified common subject NP's

2) clauses in the past tense

\section{L. Weak Environment Favoring AI}

AI is favored in clauses with unmodified common subject NP's in the future tense. Let us compare some examples with AS, AN, and $\mathrm{AI}$.

As discussed above in (29), the AS-clause in (33) focuses on the specific degree to which the given property holds in a specific temporal-modal world. The AN-clause in (34) (repeated from 
(31)), in contrast, presents the subject NP as belonging to a subset characterized the PA within a more general set.

(33) Потрасения будут грандиозны AS .- ни с чем ранее не сравнимы... (Pik. 303)

The shocks will be grandioseAS -- incomparable with anything before...

(34) Вогда ахтер будет говорить просто, а дехорафия будет вркая AN, ова өго поглотит. (Ја. 70)

'When an actor speaks [lit. will speak] in a simple manner, while the stage set is [lit. will be] loudAN, it swallows [lit. will swallow] him up.'

The AI-clause below is different from the AS- and AN-clauses above.

(35) Неухели ми, дети подполья, хивудие веправдоподобнов хизньюо застенхов, увндим сенчас

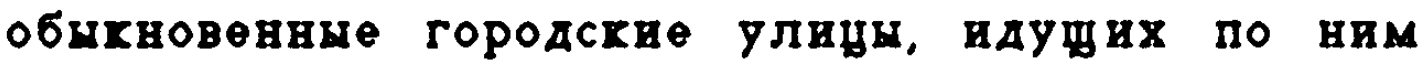
CBOбOAHUX Люден?

Юля торопливо делится своими весьма оптимистическими прогнозами: раз везут в отхритон машине, значит, рехим будет легкимАІ. Значит, все бутырские слухи о резком усилении тюремного рехима були «парашамн». (G. 192)

'Is it really the case that we, children of the underground, who are leading an implausible life of torture chambers, will 
now get to see ordinary city streets and free people walking along them?

Julia shares her rather optimistic prognoses [with others] right away: if they transport us in an open vehicle, this means that the conditions will be light $\mathrm{Al}$. This means all the rumors in Butyrskaja Prison about the sharp aggravation of the prison conditions were "crap".'

In (35) the validity of Julia's prognoses is contingent on another condition. Thus, if the prisoners were not being transported in an open car, Julia would not come up with the given prognosis.

The following example with AI can also be considered distinct from the AS- and AN-clauses above.

(36) В 10.45 орудия отхроют с того берега огонь по яповско переправе, правда, на предельнов диставдии, добавлял начальних штаба, предупрехдая төм самкм, что огонь будет мало денственним.AI (S. 135)

'And at 10:45 the guns will open fire from that shore to the passage of the Japanese, admittedly, at a maximum distance, the chief of the headquarters added, warning by this that the fire would be barely effectiveAI.'

In the text above, the staff-captain reports to a commander positioned on one side of the river that the weapons will open fire on the enemy on the other shore, but under a very severe condition. In other words, the Al-clause can be understood as 
contrasting the given condition (firing at a maximum distance) which causes the fire to be barely effective and the more desirable condition (firing at a closer range) which would cause the fire to be effective.

Examples (35) and (36), then, suggest that an AI-clause in the future tense involves two distinct conditions, $Q$ and $\sim Q$ : condition $Q$ triggers property $P$ to hold of entity $x$, and condition $\sim Q$ triggers $\sim P$ to hold of entity $x$. Since the given situation $P(x)$ comes into being provided that a specific condition holds, AI-clauses in the future tense can be considered as having a resultative meaning, as Mrázek observes (1964:223-224).

\section{2. Other Environments}

In other environments $\mathrm{AI}$ is not the most favored form. We will examine the samples in the future tense and those in the past tense separately.

\section{2. 1. Clauses with Pronominal and Proper Subject NP's and}

\section{Modified Common Subject NP's in the Future Tense}

The AS-clause in (37) below (repeated from (28)) focuses on the specific intensity of the property. The AN-clause in (38) (repeated from (30)) presents the entity as belonging to a subset within a more general set of 'general tones [of face]'.

(37) И бон этот будет жестохAS. (Pik. 472)

'And that battle will be fierceAS.' 
(38) На свон волосы я наложу сөдую нахладху, общй тон лида будет темнын AN, [...] (క. 308)

'On my hair I will put a gray hair piece, the general tone of face will be dark ${ }^{A N},[\ldots]^{\prime}$

The following Al-clause yields a different interpretation of the property.

(39) Балтйским флотом стал хомандовать Василин Алехсандрович Канин -- неприметныи вире-адмирал с лиром разочарованвого в хизни учителя вз провиндин. В хают-гомпаниях кораблеи (...) қарило всеобщее ункние [...]

Офидери негромхо переговарнвались:

-- С хончиною Эссена флот осиротел, му потеряли опитного стратега. Нихолай Оттововнч не виноват, что хайзер отодвинул нас $\mathbf{x}$ Ирбенам. В любом случае вторая военная навигафия будет слохнон AI... (Pik. 96)

'Vasilij Aleksandrovič Kanin started commanding the Baltic fleet -- an undistinguished vice-admiral with a face of a teacher from the province disappointed in life. In the wardrooms [...] general depression reigned. [...]

The officers quietly exchanged remarks:

"With the death of Essen the fleet has become orphaned, we have lost an experienced strategist. Nikolaj Ottonovič is not guilty in the fact that the Kaiser moved us aside to 
Irbeny. In any case the second military navigation will be complicated AI....'

In (39), the Al-clause is uttered by the officers who had just lost their excellent commander. Just like (35) and (36), the clause can be interpreted as contrasting two conditions and two situations contingent upon them: with Kanin the navigation will be complicated, while with Essen it might not have been complicated.

The following example also focuses on a contrast between two conditions.

(40) А в те ГОди ивогда отең, видя, что д не понимал чөГонибудь в роли, питался передать мне интонаџию «с голоса», это всөГда вивывало во мне сильнин протест, и в крнчала: «я сама, сама нафду, не мешанте мне |»

Bедь вернонAl 6удет тольхо та внтонаяия, хоторая согрөта изнутри чувством, мислью человеха, чен образ я долхна воссоздать. Значит, главное -- это пронихнуть в глубь харахтера, влезть «в хоху денствующего лища». [...) А подрахание чухим интондиям даст лишь внешнюю pacкраску роли. (Ja. 57)

'But during those years my father, noticing that I had not understood something in the role, sometimes tried to convey to me the intonation "from the voice", this always aroused a strong protest in me, and I shouted: "I will find it by myself, by myself, don't bother me!" 
After all, only the intonation which has been made real [lit. warmed up] from within -. through the feeling, through the thought of the person whose image I should create -will be genuineAI. That is, the important thing is to penetrate the depths of the personality, to get into "the skin of the character". And an imitation of other people's intonations would only give an external coloring of the role.'

In (40) the first paragraph suggests a condition for generating an intonation -- learning from "the voice". The second paragraph, which includes the Al-clause, presents another condition for generating an intonation -- building intonation through the feeling. The Al-clause can thus be understood as contrasting two possible conditions and reports that only one of them generates a situation in which the resulting intonation is genuine.

Examples (41) and (42) below both have pronominal subject NP's. The AS-clause in (41) (repeated from (16)) implicitly refers to a specific individual ('with you') with which the property held. (41) -- Павел Ефимович, позвольте, я буду честен АS ... До сих пор я не верил в боеспособность флота. (Pik. 606) 'Pavel Efimovič, excuse me, I will be honest ${ }^{A S}$... Until now I have not believed in the fighting efficiency of the fleet.'

The Al-clause in (42) yields a different interpretation.

(42) Встреча с Лазаренко имела для меня большое значение еще и потому, что он убедил меня, взрослого 
чөловеха, а мне било тогда ухе триддать лет, поступить в школу.

-- Не будешь по-настоящему грамотнимAI, не смохешь бить и настояшим артистом, -- убехдал ов. И я пообедал ему, что в этом хе году поступлю в шхолу. (T. 117)

The encounter with Lazarenko had a great significance for me also because he convinced me, a grown-up person, incidentally I was then 30 years old, to start school.

"If you are not [lit. will not be] truly literateAI, you will not be able to become [lit. be] a genuine performer either," he argued. And I promised him that I would start school that year.'

The AI-clause above can be read as follows: 'if you do not become literate in the real sense, you will not be able to become a real comedian; if you do become literate, however, you might be able to become a real comedian'. The focus of the AI-clause is on the contrast between two conditions which yield two possible consequences.

We will now turn to examples in the past tense, an environment in which $A I$ is less favored than in the future tense. 6. 2. 2. Clauses in the Past Tense

The following AS- and AN-clauses with the adjective веселы 'cheerful' are repeated from (14) and (15). In (43) the property is 
restricted to a specific degree in the given domain, while in (44) the individual is viewed as a type within a set.

(43) Рамов бил веселАS, шутил, благодарил за теплме слова в адрес испавской хоманды. (В. 39)

'Ramon was cheerfulAS, cracked jokes, expressed thanks for the heart-warming words addressed to the Spanish crew.'

(44) Тетя, Агафья Яховлевна, [...] [ø] была очень веселаяАN, милая AN, отлично пела русские песни. (ड். 9)

'My aunt, Agafja Jakovlevna, [...] [she] was very cheerfulAN, sweet $A N$, excellently sang Russian songs.'

Example (45) contains AI of the same adjective.

(45) -- Мохет быть, вц хотите что-нибудь схазать, Е. С.? -хриплмм голосом спрашивает Бихташев, не подннмая глаз, опушенных на лехашее перед ним «дело». [...]

Паува. Теперь ми с Бикташевым смотрим друга другу в глаза. Перед вами вознихают одни в те хе хартину прошлого... Десять лет тому назад я, молоденькая начинаюшая преподавательнида, учу его, [...) пришедшего из деревни. (...] Столько их било -трудностеи, радостей преодоления, исправленных тетраден. Кахими ови била веселимиА и любовнательнымиАІ, эти узкие монгольские глазхи! и хакие они тусхлые и покрасневшие сеичас... (G. 44) 
"Maybe you want to say something, E. S.?" Biktašev asks in a hoarse voice, not raising his eyes directed down at the "case" which was lying in front of him. [...]

Pause. Now I and Biktašev are looking into each other's eyes. In front of us the same scenes from the past arise... Ten years ago, I, a young beginning instructor, am teaching him, [...] who has come from a village. [...] How many were there -- difficulties, joys of conquering, corrected notebooks. How they were cheerfulAI and curious ${ }^{A I}$, those narrow Mongol eyes! And how dull and red they are now...'

The context contrasts the given properties which held in one temporal domain and the properties of the same individual which held in another temporal domain.

The following set of examples all have modified common subject NP's and the adjective огромны 'huge'.

(46) И на хах до [харчевне) висела вувеска: «Только у нас настояџй борџ. Бонтесь подАелки, будут болеть животҢ》

Еще нздали охоло харчевен виднелись длинные столь, застланвые белон тханью. На столе стояли глиняные махнтры, нехоторые были огромны AS, до пяти ведер емхостью. [...] охоло хаждон махитры стояли глубокие глинянше чашхи и деревянные расхрашенные ложки. Молодые хазачки в национальных хостюмах $[. .$. 
воорухеннуе длиннмми Половнихами, стояли в полнон бOEBOA ГОТОВНОСТи.

(...) Борт был тахон сытнын, что редко хто просвл вторую порџию. (Т. 91)

'And at every [eating-house] there was a sign: "Only we have the genuine boršc. Beware of fakes, your stomach will hurt."

Already from afar, near the eating-houses, one could see long tables covered with white cloth. On the table there were clay containers, some of them were hugeAS, up to five buckets in capacity. [...] Near each of the containers there were deep clay cups and painted wooden spoons. Young Cossack women in their national costumes [...], armed with long serving spoons, stood fully ready for action.

The boršc was so filling that hardly anyone asked for a second helping.'

(47) В тридвати Авух городах побнвали ми с «Лохьго летом 1929 года. Сиграли семьдесят спектаклен. Интерес х спектаклю всюду был огромнынАN. (5். 212) 'In the summer of 1929 we played "The Lie" in thirty-two cities. We performed 70 times. Everywhere the interest in the performance was enormous ${ }^{A N}$.'

The AS-clause in (46) presents the property as being graded. The property in this clause holds true to the extent specified by the immediately following prepositional phrase. The whole text is about the taste of the famous Kuban borš $c$ and its large quantity. 
The size of the some of the pots containing bors $\check{c}$ is one of the items used to emphasize these two points. Thus, the AS-clause is best interpreted as focusing on the degree to which the property held.

In (47) the PA-clause is preceded by a text which refers to different places where the speaker's theater performed the same play. The subject does not refer to a unique entity, but rather to the audience's interest in the performance given by the theater in general. In other words, this $\mathrm{AN}$-clause presents the subject as a type within a general set of interest in the performance; it belongs to the subset characterized by being enormous.

The Al-clause below yields an interpretation distinct from both the AS and AN.

(48) О Махшеөве совсем ничего не написано, а гахо это яркии реалистически талант! Он был предельно прост и исхренен на сдене, у него был юмор какон-то особон мягхости, что отличало его от остальных хомихов. Но эта мягхость была обманчива -- разоблачительная сила өго юмора была огромнонАІ. Особенно проявлялось это в роли городничего. [...] никогда я не видела столь в ы см я я н ог г городничего, как городничй Махшеева. (Ja. 130)

'About Makšeev there is nothing written at all, but what a bright realistic talent he is! He was simple to the extreme and sincere on stage, he had humor of some special softness, 
which made him distinct from the other comic actors. But this softness was misleading -- the power of his humor to expose was hugeAl. This became apparent especially in the role of the governor. [...] I have never seen a ridiculed governor such as the one played by Makšeev.'

The AI-clause in (48) is preceded by a text about Makšeev's 'soft' sense of humor and a potential misunderstanding of the addressee arising from it. The Al-clause, then, can be understood as correcting such a misguided assumption; it negates the assumption that Makšeev's humor lacked the ability to expose evils due to its softness and that Makšeev therefore failed to be a realist. This Al-clause can thus be interpreted as contrasting the addressee's possible assumption and what the speaker considers to be the real situation.

The following set of examples involves the adjective привлехательни 'attractive'.

(49) Кроме Нини Внардо мне понравился дуэт Лидии и Нихолая Коварских, исполнявших провэведения Чехова, Беранже, Аверченко и сденки, написанные самим Коварским. ПривлекателенAS был и шуточнын лубох с тавнами и qастушхами Матрени в Анатолия Бог дановича. (Т. 92)

'Besides Nina Viardo I liked the duet of Lidija and Nikolaj Kovarskij, who performed works by Čexov, Beranže. Averčenko, and skits written by Kovarskij himself. The 
comic play with dances and verses of Matrena and Anatolij Bogdanovič was also attractive ${ }^{A S}$.'

(50) Мне он предлохил ездить вместе с ним и выступать после сеансов. В общем-то это дело було не очень привлехательноеАN, но Аполлонскин соблазнил меня... рехламон. (Т. 121)

'He suggested to me that I travel with him and perform after his shows. In general this work was not very attractiveAN, but Apollonskij tempted me... with the advertisement.'

The PA-clause in (49) is presented from the speaker's viewpoint; it is a statement made as a result of his observation. The property is restricted to a specific perspective.

In example (50) the PA-clause is preceded by a characterization of what type of work Apollonskij offered to the speaker. The subject NP in the AN-clause can thus be understood as a type in this context: 'this work .- the kind of work which he described to me -. was not attractive': the work belongs to a subset defined by the PA.

The following example with AI is distinct from the AS- and AN-counterparts.

(51) Оскудевшая Гредия в 1912 году уже не владела своими природными богатствами. Каменоломни Пентеликона принадлежали англичанам. У этих новых хозяев мы и покупали пентеликонскии мрамор. Отобрали несколько 
хрупных блохов и взяли вдобавок Груду мраморних обломков с самородками. ЭТи обломки были необычно привлехательнымиАІ хах по форме, тах и по своен оригинальнон структуре. Они были усеяны друзами и хрупними христаллами. (Kon. 177-178)

'Greece in 1912, which had become decimated [in resources], no longer possessed its natural riches. The quarries at Pentelikon belonged to the English. From these new owners we bought Pentelikon marble. We picked out some big blocks and took, in addition, a pile of marble fragments with native metals. These fragments were unusually attractiveA 1 both in form and in original structure. They were studded with holes and big crystals.'

Example (51) is preceded by a text describing a situation in Greece, which no longer possessed good marble for sculpture. The discovery of these unusually attractive fragments is therefore an unexpected surprise for the speakers. The Al-clause, in other words, can be interpreted as contrasting the speakers' prior expectation and the newly affirmed reality: they had not expected much good material for sculpture in the quarry, but they unexpectedly came upon these fragments which turned out to be very attractive.

The PA-clause below also contrasts the individual's prior expectation and the newly discovered reality. 
(52) Работал над спехтахлем Пельтдер по-ахтерсхи. Интөресное решение отдельних сден не всегда слагалось В интересное велое. НАед спектакля оставалась тумавнов.

НеудачнонAl била ивсденировка. Знахомясь с ролью, д с Удивлением выяснила: Марфинька -- водевильнин персовах ? Смеется, ваввничает, влюбляется, а мислев в голове никахих? (S. 87)

'Pel'tcer worked on the play like an actor. His interesting treatment of individual scenes did not always yield an interesting whole. The idea of the play remained nebulous.

The adaptation was unsuccessfulAI. While studying the role, I found out: Marfinka is a vaudeville personage? She laughs, acts naive, falls in love, and there are no thoughts in her head?'

The interpretation is supported by the text following the PAclause; it describes, from the individual's internal perspective, the speaker's surprise when she encountered Pel'tcer's adaptation.

The examples in the past tense above, like the examples in the future tense, indicate that an AI-clause involves two distinct worlds. Like the examples in the future tense, many of the examples in the past tense can also be considered as resultative; they report a newly discovered reality (the property $P$ came to hold of the entity $x$ at a specific modal-temporal point, prior to which $\sim P$ had been or might have been expected to hold of $x$ ). 
These examples, then, may be equivalent to the constructions with the verb охазаться 'to turn out to be' and a PA. Example (45), however, indicates that some AI-clauses in the past tense may not be resultative; they may report cancellation of the given state, contrasting the temporal world in which the property used to hold of the entity and the temporal world (simultaneous with the speech event) in which the property no longer holds. What is common to all the Al-clauses presented above is that they all involve contrast between two distinct worlds: the given world in which the property holds and the alternative world in which the property does not hold.

In the subsequent section I will summarize the relationship among the three PA forms.

\section{3. Conclusions to Part II}

The individual examples with $A S, A N$, and $A I$ above indicate that AS-, AN-, and AI-clauses consistently yield specific interpretations. AN-clauses report that $x_{1}$, a member of a set of entities $X$, belongs to a subset defined by the property $P$. ASclauses report that, in $w_{1}$, in a member of a set of possible worlds $W$, the property $P$ holds of the entity $x$ to a specific degree $y 1$.

The individual examples suggest that AI-clauses are different from both AS- and AN-clauses. AI-clauses, unlike AN-clauses, contrast the given world and another world. 
Al-clauses may seem similar to AS-clauses in that they report restriction on the property, but AS- and AI-clauses are different in two respects. First, AS- and Al-clauses can be differentiated with respect to the presence of a clear boundary between the world in which $P$ holds and the world in which $\sim P$ holds. ASclauses simply report that there is a restriction on the property in a specific world. They therefore allow an interpretation that the property might hold to different degrees or might not hold at all in other worlds; the given world belongs to a set of worlds which form a continuum in which the property holds from the minimum (= zero) to the maximum degree. In this sense, the given world $w_{1}$ in which the property $P$ holds can be viewed as "open", since there is no clear boundary between the world in which $P$ holds and the world in which $P$ does not hold. AI-clauses, in contrast, specify two distinct worlds or conditions: one in which $P$ holds and the other one in which $P$ does not hold. In other words, the world in which $\mathrm{P}$ holds in an AI-clause can be viewed as "closed".

The second difference between AI- and AS-clauses is connected with the presence and absence of "closure"; it has to do with difference in the point of perspective from which the property is viewed. An AS-clause views the situation from within the given world $w_{1}$ in which the property holds to a specific degree, and therefore remains unclear about whether $P$ holds outside of $w_{1}$, namely in other worlds which also belong to the set W. An Al-clause, in contrast, views the situation from outside of 
the given world; thus, the given world, viewed in this manner, is presented as enclosed by a clear boundary, beyond which the property does not hold. The models for AS- and AI-clauses, then, are similar to those used in Timberlake 1982:311-313 in which the imperfective and perfective aspects are characterized as "open" and "closed" with respect to the "aspect locus". The need for a semantic element similar to aspect locus in describing AIclauses is supported by Mrázek's description of AI-clauses as having resultative aspectuality (1964:223-224) and Chvany's observation that the future forms of $6 \mathrm{WTb}$ (which correlates with Al) may have a perfective meaning (1975:90).

The semantics of an AI-clause can be graphically represented as follows:

\section{Eigure 7. Semantics of an Al-clause}

In the future tense, the contrast involves two conditions; under one of them $P(x)$ holds. In the past tense it involves a contrast between the prior expectation and the newly discovered reality, or a contrast between a situation in the past and a situation in the present. 9 
This property of AI-clauses perhaps explains why AI does not correlate with referential uniqueness of the subject NP as consistently as AN. In my analysis of AS-clauses in section 5. 4, I argued that the subject NP of the clause is likely to, but does not necessarily, invoke an interpretation that the subject NP be viewed as unique, because AS-clauses present the given property Py 1 as one of the many possible properties Py $1 \ldots y$ which might hold of entity $x$ in the possible worlds $w_{1} \ldots n$. Unlike AS-clauses, AI-clauses contrast two and not more than two worlds; this, then, suggests that the given property is viewed as one of the only two properties of the entity $x$. Consequently, AI-clauses are more likely to present the subject referent as a unique entity than ANclauses, for which contrast with alternative properties is irrelevant; AI-clauses, however, are less likely to present the subject referent as unique than AS-clauses, which present the property as one of an unspecified number of alternative properties of the subject. This explains why Al-clauses do not correlate with referential uniqueness as consistently as AS- or AN-clauses.

The semantics of AS-, AN-, and AI-clauses is summarized below. Here, " + " indicates the presence of the given semantic property (represented in square brackets [ ]), while "-" indicates its absence. As shown below, AS-, AN-, and AI-clauses all have positive values. 


\section{Table 9. Semantic Properties of AS-Al-_and AN-clauses}

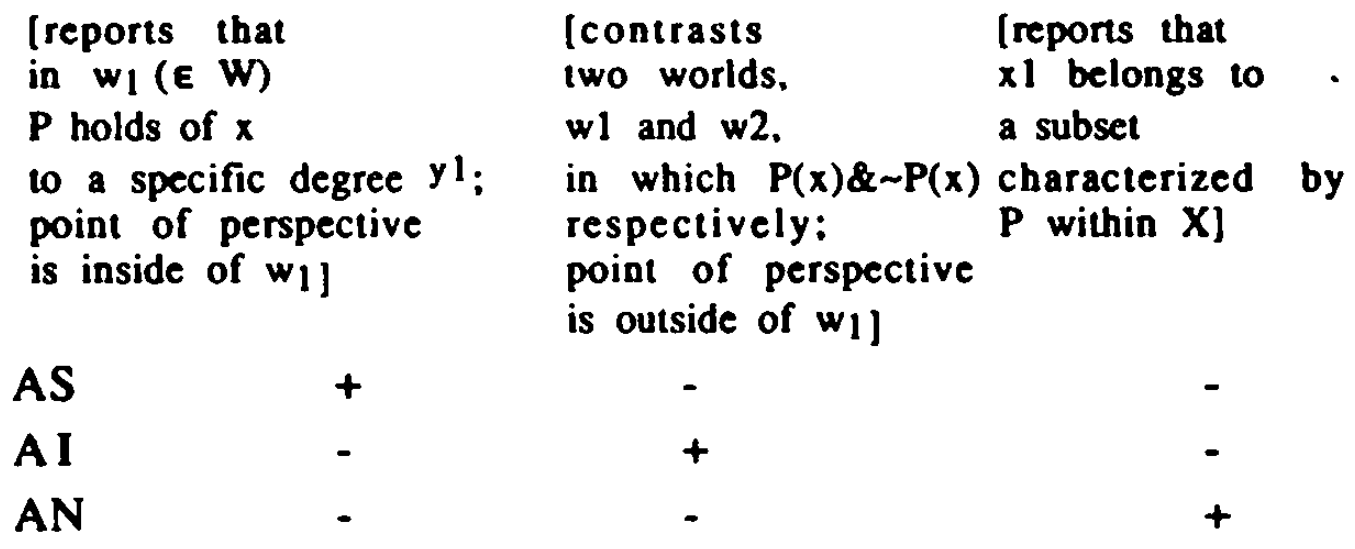

Let us now attempt to formulate the necessary conditions for the three PA forms. Figure 8 below shows the levels at which PA forms are selected. A solid line parallel to a form indicates that the given form is nearly automatically selected in the given environment, while a dotted line parallel to a form indicates that the given form is selected with less automaticity. Constructions with complements and counterfactual and concessive clauses almost automatically focus on the specific world in which the property holds to a specific degree. These parameters, regardless of context, nearly automatically trigger AS. In contrast, in the future and past tenses, form selection is not as automatic as the two aforementioned strong environments, but is heavily dependent on the contextual interpretation of the clause. When context presents the given world as a member of a set of worlds - with the point of perspective internal to the world -- and presents the property as being valid to a specific degree, AS is selected. Future tense forms of быть, which may behave like a 
perfective verb, favors AI, but the occurrence of $\mathrm{AI}$ is heavily dependent on a context implying contrast between two possible worlds. AN is favored by low referential uniqueness of the subject NP, but the form is selected when context presents the subject NP as a member of a set.

\section{Figure 8. PA Form Selection}

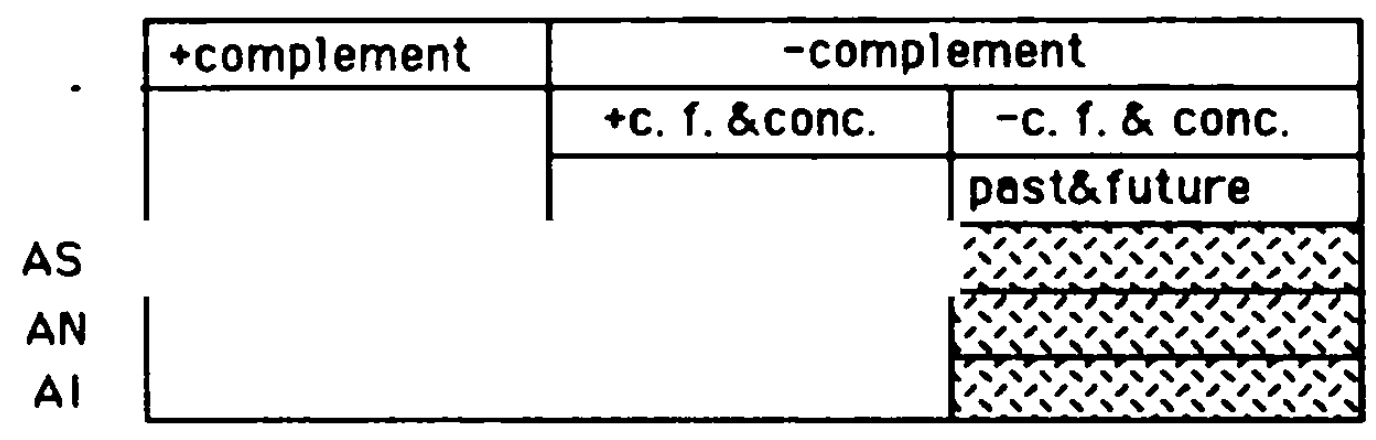

The semantics of AS-, AI-, and AN-clauses suggests differences among the PA-clauses in terms of informational structure. I have argued in section 5. 4 that much information about the subject NP of AS-clauses is likely in the addressee's preexisting knowledge, while the opposite is true of AN-clauses. AI-clauses, in contrast, can be considered as having an intermediate informational structure. As discussed above, the property in an Al-clause is presented as one of only two possible properties of the subject referent. Consequently, the subject referent of an AI-clause is less likely to be viewed as unique than that of an AS-clause, but it is more likely to be viewed as unique than that of an AN-clause. 
This seems to be commensurate with Potebnja's observation (1888/1958:504) that AI form implies the presence of an alternative property which "is about to come into the speaker's consciousness"; this suggests that the subject referent of an AIclause is moderately activated in the discourse.

The informational structures of AS-, AI-, and AN-clauses can thus be graphically presented in Figure 9. 
perfective verb, favors AI, but the occurrence of AI is heavily dependent on a context implying contrast between two possible worlds. AN is favored by low referential uniqueness of the subject NP, but the form is selected when context presents the subject NP as a member of a set.

\section{Fiqure 8. PA Form Selection}

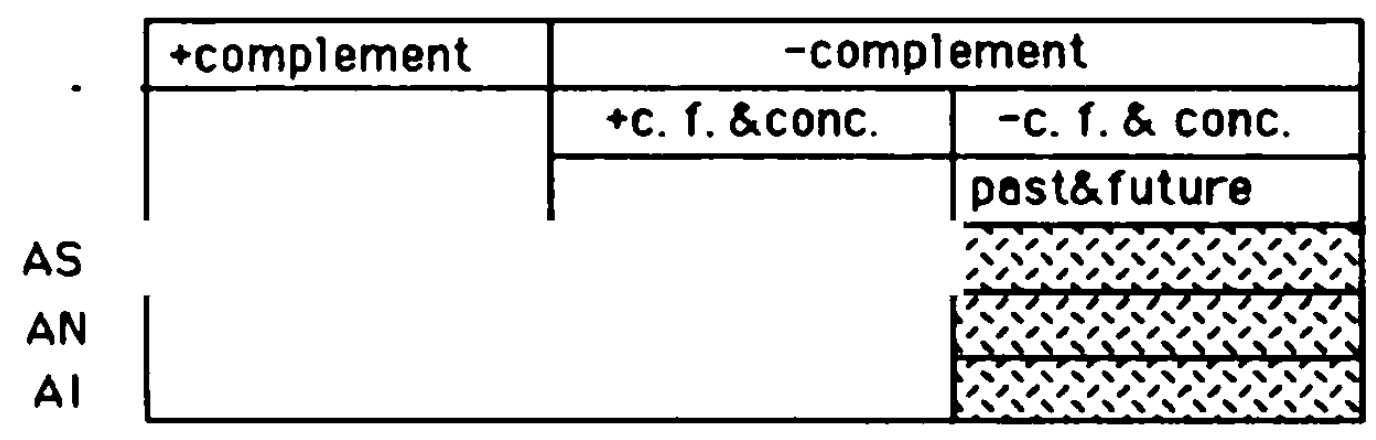

The semantics of AS-, AI-, and AN-clauses suggests differences among the PA-clauses in terms of informational structure. I have argued in section 5. 4 that much information about the subject NP of AS-clauses is likely in the addressee's preexisting knowledge, while the opposite is true of AN-clauses. Al-clauses, in contrast, can be considered as having an intermediate informational structure. As discussed above, the property in an AI-clause is presented as one of only two possible properties of the subject referent. Consequently, the subject referent of an AI-clause is less likely to be viewed as unique than that of an AS-clause, but it is more likely to be viewed as unique than that of an AN-clause. 
This seems to be commensurate with Potebnja's observation (1888/1958:504) that AI form implies the presence of an alternative property which "is about to come into the speaker's consciousness"; this suggests that the subject referent of an AIclause is moderately activated in the discourse.

The informational structures of AS-, AI-, and AN-clauses can thus be graphically presented in Figure 9. 


\section{Figure 2. Addressee's Knowledge about the Subject Referent in}

\section{PA-clauses}

$\square$ oddressee's knolwedge unreloted to

the subject referent

properties of the subject referent

unknown to the oddressee

properties of the subject referent

known to the addressee

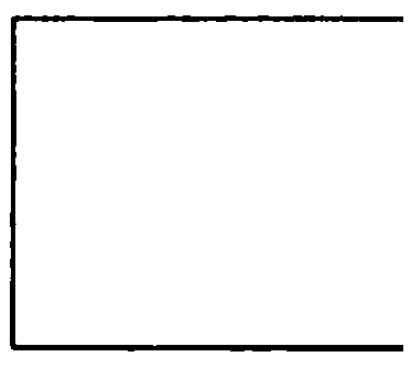

subject referent

of on AN-clouse

subject referent

of an Al-clouse

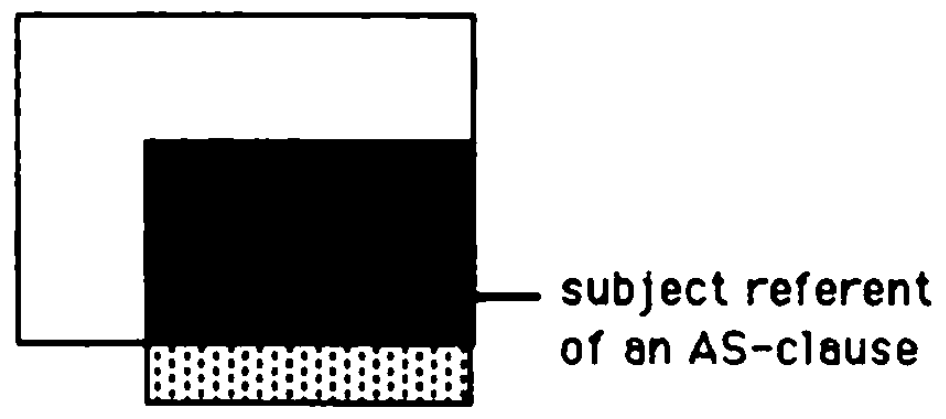


The relationship between the subject NP and the amount of information the speaker assumes the addressee has about the subject referent is illustrated by the dark portion of the area representing the subject referent.

As shown below, the differences in discourse function among AS-, AN-, and AI-clauses can be represented in terms of their informational structures: the speaker's evaluation of the amount of knowledge which the addressee is likely to have concerning the subject referent. 
description (1966:285). In the example used by Donnelan below, it is irrelevant whether the speaker knew who killed Smith (or even how many people killed Smith). The definite expression "Smith's murderer" reports whoever that fits the description of having killed Smith.

(i) Smith's murderer is insane.

In other words, the definite subject NP presents the individual as belonging to the subset of "Smith's murderer" within a general set of people.

8. Support for the speculation that the semantics of a certain type of PA-clause might involve tense-aspect-modality can also be found in other languages. In Polish the instrumental case is said to denote temporalized, modalized, and aspectualized properties as opposed to the nominative, which is descriptive (Rothstein 1986). Similar phenomena can be seen in non-Slavic languages, such as Finnish (Elliot 1890), Turkish (Underhill 1976), Thai (Kuno and Wongkhomthong 1980), and Lithuanian (Timberlake 1987).

9. This observation might lead one to a question why AS correlates with counterfactuals more significantly than AI in my data. The meaning of conditionals, however, does not seem to strictly boil down to a contrast between two conditions. Rather, it seems more likely that conditionals (including counterfactuals) express various degrees of hypotheticality (Comrie 1986:88) or 
the spezker's uncertainty or uncontrollability of the given situation (Akatsuka 1986:344). 
General Conclusions

In the discussion above, I presented specific conclusions on case selection in the object of negated transitive verbs and on form selection of predicate adjectives. It is, however, possible to state three general points which unify the thesis as a whole. First, I have identified strong and weak environments in which the two instances of morphosyntactic variation are determined to varying degrees of automaticity. Second, I have employed a similar strategy in the description of the two morphosyntactic processes, which made more precise some of the intuitions and notions which have been previously used. And third, I have pointed out the correlation between these morphosyntactic processes and discourse considerations.

The first general point which 1 made in this thesis is that there are different environments in which context exerts influence on the morphosyntactic processes to different degrees. In what I labeled as "strong" environments, selection of the appropriate form is more automatic than in "weak" environments. The degrees of automaticity in the two morphosyntactic processes are presented in Figures 4, 5, and 6 from Part $I$ and Figure 8 from Part II.

In strong environments the clause-level parameters nearly automatically impose one specific interpretation of the clause, and consequently they consistently assign a specific form correlated with this interpretation. In weak environments the clause-level 
parameters tend to assign one specific interpretation, but the interpretation of the clause is also dependent on the context. The two instances of morphosyntactic variation examined here are then results of the tension between clause-level parameters and context; these compete with each other to impose a certain interpretation on the given clause.

The second point which I made in this thesis is that clauses with a variant from each of the morphosyntactic processes can be reduced to a specific abstract semantic model involving a limited number of semantic primitives. This strategy presents a clearer picture of the difference between the two types of negative clauses (A- and G-clauses) and of the difference among the three types of PA-clauses (AS-, AN-, and AI-clauses).

Thus, in clauses with negated transitive verbs, A-clauses can be said to individuate a distinct element $\left(x_{1}\right)$ out of a set $(X)$ of comparable elements. In contrast, G-clauses invoke a type or set of entities $X$ and reports the existence or nonexistence of any of its members $\left(x_{1} \ldots n\right)$, without distinguishing any particular member or members from others. In this sense G-clauses can be said to yield existential interpretation of some element. I have argued that individuation as well as existential interpretition may operate on different levels: on the lexicosemantic level, on the temporalaspectual-modal level, or on the textual level.

These set representations offer a more precise account of the intuitions about A- and G-clauses in Tomson 1903, in which A- 
clauses are said to imply the corresponding affirmative situation, while G-clauses are said to present a state of nonexistence of some entity resulting from the given negative situation. Also, the models above extend the notions of individuation and existential interpretation, which tend to be used for individuation or existentiality of entities, to more abstract levels such as properties, temporal-aspectual-modal domains, and texts.

The set-member model can be applied to the semantics of the three types of PA-clauses as well. AN-clauses report that a member $x_{1}$ of a set of entities $X$ belongs to a subset defined by the property $P$. AS-clauses report that in a specific member $w_{1}$ of a set of worlds $W$ the property $P$ holds of the given entity $x$ to $a$ specific degree $\mathrm{y}^{1}$. Al-clauses contrast two distinct worlds: one in which the property $P$ holds of the entity $x$, and another in which it does not. In addition to sets and members, I also introduced another primitive, point of perspective, to differentiate AS- and Al-clauses; in the former the point of perspective is internal to the given world, while in the latter it is external to the given world.

The fact that the two types of morphosyntactic variation can be described in terms of similar set of primitives, namely sets and members, suggests that these may belong to the basic semantic components utilized by native speakers of Russian in resolving morphosyntactic fluctuations. Also, by using a primitive called point of perspective in my analysis of AS- and Al-clauses, I 
suggested the third semantic component which might operate in morphosyntactic variation in Russian. Timberlake's notion of "aspect locus" in aspectual selection in Russian (1982), a semantic primitive similar to the point of perspective, seems to justify this possibility.

The final point which can be drawn from the current thesis is that the two morphosyntacic processes are correlated with discourse.

Under negation, both A-clauses and G-clauses tend to modify the addressee's assumption, but they modify it in slightly different manners. A-clauses are likely when the speaker assumes that the addressee entertains some property $P$ about a set of elements; the negative clause singles out an entity out of the set as distinct or exceptional in that it does not share the same property $P$ with the other members of the set. G-clauses, in contrast, are likely when the speaker assumes that the addressee presupposes the existence of a set of elements with a certain property $P$ in a certain domain; G-clauses modify this assumption by denying the existence of any of such elements in the domain.

PA-clauses are correlated with discourse somewhat differently from negative clauses. True, Al-clauses may be similar to A- and G-clauses in that they can involve modification of the addressee's prior knowledge, since they may report a newly discovered reality, but the major distinction in discourse function among the 
PA-clauses lies in the amount of (what the speaker evaluates to be) the addressee's preexisting knowledge.

AN-clauses report that the given entity belongs to a subset chararacterized by the given property, within a more general set of comparable entities; these clauses allow an interpretation that there might be other members of the set which are characterized by the same property. It follows that $\mathrm{AN}$, in comparison to the other two PA-forms, is more likely to be correlated with a context in which very little information about the subject referent (which would identify the entity as distinct from all the other members of the set) is available in the addressee's preexisting knowledge.

AS-clauses report that in a member of set of worlds the property holds of the subject referent to a specific degree. Thus, AS-clauses are likely to present the predication as one of the possible properties of the entity. Consequently, the subject NP is likely to be viewed as unique and is likely to be in a context in which considerable information about the subject referent is available in the addressee's preexisting knowledge.

As for Al-clauses, they report two worlds -- one in which the property holds for the entity and the other in which it does not. AI is then likely when some information about the subject referent is available to the addressee prior to the PA-clause. In this sense, AI-clauses are like AS-clauses. AI-clauses, however, differ from AS-clauses in that they focus strictly on two distinct worlds. AI-clauses are therefore less likely to present the entity 
as unique than AS-clauses; rather, they are likely to correlate with a context in which the addressee entertains only one alternative property about the subject referent. As a consequence, Al-clauses can be considered as an intermediate type with respect to the amount of information which is likely to be available to the addressee. The relationship between the addressee's preexisting knowledge and the three types of PA-clauses is illustrated in Figure 9 in Part II.

The investigation of the semantics of negative and predicate adjective clauses thus not only accounts for the occurrences of variants, but also supports the hypothesis put forth by many discourse-oriented studies that morphosyntactic processes interact with discourse. Furthermore, the present thesis has indicated two different manners in which morphosyntactic variation may interact with discourse: A/G selection correlates with different ways in which the addressee's knowledge is modified, while PA-clauses correlate with the amount of information available in the addressee's preexisting knowledge.

To conclude, the contribution of the present thesis can be summarized as follows: I have observed that the two instances of morphosyntactic variation are conditioned by tension between clause-level parameters and context competing to impose an interpretation on the clause; I have adopted a similar set of primitives to account for both types of variation and suggested that they might belong to the general set of basic semantic 
components which operate in morphosyntactic variation in
Russian; and I have pointed out different manners in which

components which operate in morphosyntactic variation in
Russian; and I have pointed out different manners in which morphosyntactic variation may correlate with discourse. morphosynactic variation may correlate with discourse. 


\section{Sources}

B = Botin, M. P. 1976. S toboj. Ispanija. Moscow: Voennoe izdatel'stvo ministerstva oborony SSSR.

C = Cvetaeva, A. 1983. Vospominaniia. 3rd ed. Moscow: Sovetskij pisatel'.

G = Ginsberg, E. 1985. Krutoj_maršrul, vol. 2. 2nd ed. New York: Possev-USA

$\mathrm{Ja}=$ Jabločkina, A. 1953. Ľizn' v teatre. Moscow: Iskusstvo.

Kon $=$ Konenkov, S. T. 1971. Moj vek. Moscow: Politizdat.

Kr = Kryžickij, G. K. 1976. Dorogi teatral'nye. Moscow:

Vserossijskoe teatral'noe obščestvo.

Pik = Pikul', V. S. 1973. Moonzund. Leningrad: Sovetskij pisatel'.

Rb = Rybakov, Anatolij. 1979. Tiażelyi pesok. Moscow: Sovetskij pisatel'.

Ryl = Rylov, A.. 1977. Vospominanija. Leningrad: Xudožnik RSFSR.

$S=$ Simonov, Konstantin. Tovarišči po onı̇iill, Moscow:

Sovetskij pisatel'.

$\grave{S}=$ Śatrova, E. M. 1975. ל̇izn' moja .. teatr. Moscow: Iskusstvo.

$T=$ Taraxno, Peter. 1976. L̇izn' otdannaja cirku. Moscow: Iskusstvo. 


\section{References}

Akatsuka, Noriko. 1986. "Conditionals are Discourse-bound," in On Conditionals, ed. Elizabeth Closs Traugott, Alice ter Meulen, Judy Snitzer Reilly, and Charles A. Ferguson. Cambridge: Cambridge University Press, 333-351.

Babby, Leonard H. 1975. A Transformational Grammar of Russian Adjectives. Janua Linguarum, Series Practica 234. The Hague-Paris: Mouton.

1980. Existential Sentences and Negation in Russian

Linguistica Extranea, Studia 8. Ann Arbor: Karoma.

Bauer, Jaroslav, et al. 1966. Přiruční mluenice ruštink pro そ̌echk. vol. 2. Prague: Státní pedagogické nakladatelství.

Borras, F. M., and R. F. Christian. 1971/79. Russian Syntax: Aspects of Modern Russian Syntax and Vocabulary, 2nd ed. Oxford: Oxford University Press.

Chaput, Patricia R. 1985. "On the Question of Aspectual Selection in Denials," in The Scope of Slavic Aspect, ed. Michael S. Flier and Alan Timberlake. UCLA Slavic Studies, vol. 12. Columbus, Ohio: Slavica, 224-233.

Chvany, Catherine V. 1975. On the Syntax of BE-sentences in Russian. Cambridge, Mass: Slavica.

Comrie, Bernard. 1986. "Conditionals: A Typology," in $\underline{\mathrm{O}}$ Conditionals, ed. Elizabeth Closs Traugott, Alice ter 
Meulen, Judy Snitzer Reilly, and Charles A. Ferguson. Cambridge: Cambridge University Press, 77-99.

Corbett, Greville. 1979. Predicate Agreement in Russian. Birmingham Slavonic Monographs 7. Birmingham: University of Birmingham.

Donnellan, Keith, S. 1966. "Reference and Descriptions," Philosophical Review 75, 281-304.

Elliot, C. N. F. 1890. A Finnish Grammar. Oxford: Oxford University Press.

Forsyth, J. 1970. A Grammar of Aspect: Usage and Meaning in the Russian Verb. Cambridge: University Press.

Fox. Barbara A., and Sandra A. Thompson. 1990. "A Discourse Explanation of the Grammar of Relative Clauses in English Conversation," Language 66, 297-316.

Fuchs, Anna. 1973. "Zur Wahl des Objektkasus bei Verneinung im Russischen," in Slavistische Studien zum VU Internationalen Slavistenkongress in Warschau 1973, ed. Johannes Holthusen, Erwin Koschmieder, Reinhold Olesch and Erwin Wedel. Munich: Trofenik, 81-91.

García, Erica. 1979. "Discourse without Syntax," in Discourse and Syntax, ed. Talmy Givón. Syntax alid Semantics, vol. 12. New York: Academic Press, 23-49.

Givón, Talmy. 1976. "Topic, Pronoun, and Grammatical Agreement," in Subject and Topic, ed. Charles N. Li. New York: Academic Press, 149-188. 
. 1983. "Topic Continuity in Discourse: An Introduction," in Topic Continuity in Discourse: A Quantitative Cross , ed. Talmy Givon. Typological Studies in Language, vol. 3. Amsterdam-Philadelphia: John Benjamins, 3-41.

Green, B. D. 1979. "Factors in the Choice of the Case of Direct Objects after Negated Transitive Verbs in Russian," The Slavonic and East European Review 57, 161-186.

Gustavsson, Sven. 1976. Predicative Adjectives with the Copula byt ${ }^{\prime}$ in Modern Russian. Acta Universitatis Stockholmiensis 10 . Translated by Charles Rougle.

Stockholm: Almqwist \& Wiksell International.

Hajič ová, Eva. 1973. "Negation and Topic vs. Comment," Philologica Pragensia 90, 81-93.

Halliday, M. A. K., and Ruqaiya Hasan. 1976. Cohesion in English.

London and New York: Longman.

Hatch, Evelyn, and Hossein Farhady. 1982. Research

Statistics. Rowley, Mass: Newbury House.

Hopper, Paul J., and Sandra A. Thompson. 1980. "Transitivity in Grammar and Discourse," Language 56, 251-299.

Isač enko, A. V. 1958. Die russische Sprache der Gegenwart: Eormenlehre. Munich: Max Hueber.

1965. Grammatičeskij stroj russkogo jazyka v sopostavlenii s slovackim; vol. 1: Morfologija. Bratislava: Slovenská akadémia vied. 
Jakobson, Roman. 1932/71. "Zur Struktur des russischen Verbums," in Selected Writings; vol. 2: Word and Language. The Hague-Paris: Mouton, 3-15.

____. 1936/71. "Beitrag zur allgemeinen Kasuslehre," in Selected Writings: vol. 2: Word and Language. The HagueParis: Mouton, 23-71.

Janda, Laura. 1985. "The Meanings of Russian Verbal Prefixes: Semantics and Grammar," in The Scope of Slavic Aspect, ed. Michael S. Flier and Alan Timberlake. UCLA Slavic Studies, vol. 12. Columbus: Slavica, 26-40.

Klenin, Emily. 1978. "Quantification, Partitivity, and the Genitive of Negation in Russian," in Classification of Grammatical Categories, ed. Bernard Comrie. International Review of Slavic Linguistics, vol. 3. Edmonton: Linguistic Research Inc., 163-182.

Korn, David. 1967. "Case Selection: Genitive or Accusative after Negation in Contemporary Russian?," Modern Language Review 62, 486-497.

Kuno, Susumu, and Preya Wongkhomthong. 1980. "Two Copulative Verbs in Thai," in Harvard Studies in Syntax and Semantics, no. 3, ed. Susumu Kuno. Cambridge, Mass.: Harvard University, 243-316.

Labov, William. 1972. Language in the Inner City: Studies in the Black English Vernacular. University of Pennsylvania 
Publications in Conduct and Communication 3 .

Philadelphia: University of Pennsylvania Press.

Lyons, John. 1977/1988. Semantics, vol. 2, 2nd ed. Cambridge:

Cambridge University Press.

Magner, Thomas F. 1955. "Negation and Case Selection in Russian," Word 11, 531-511.

Morison, W. A. 1964. "Logical Stress and Grammatical Form in Russian," Slavonic and East European Review 42, 292 311.

Mrázek, Roman. 1964. Sintaksis russkege troritel'nego (strukturno-sravnitel'noe issledovanie). Prague: Státní pedagogické nakladatelství.

Mustajoki, Arto. 1985. Padez dopolnenija y russkix otricatel'nyx predloženijax, vol. 1: Izyskanija novyx metodov $v$ izučenii staroj problemy, Slavica Helsingiensia, no. 2. Helsinki: University Press.

Nichols, Johanna. 1981. Predicate Nominals: A Partial Surface Syntax of Russian. University of California Publications in Linguistics, no. 97. Berkeley-Los Angeles-London: University of California Press.

Peś kovskij, A. M. 1914/1956. Russkij sintaksis v naučn om osveščenii, 7th ed. Moscow: Ućpedgiz.

Polanyi, Livia. 1985. Telling the American Story: A Structural and Cultural Analysis of Conversational Storytelling. Language and Being. Ablex: Norwood. 
Potebnja, A. A. 1888/1958. Iz zapisok po russkoj grnmmatike, vols. 1-2, 2nd ed. Moscow: UČpedgiz.

Restan, Per A. 1960. "The Objective Case in Negative Clauses in Russian: the Genitive or the Accusative?," Scando-Slavica 6. $92-112$.

Rothstein, Robert A. 1986. "Equation vs. Ascription: The Nominative/Instrumental Opposition in West Slavic," in Case in Slavic, ed. Richard D. Brecht and James S. Levine. Columbus: Slavica, 312-322.

Røed, Ragnar. 1966. Zwei Studien ïber den prädikaten Instrumental im Russischen. Oslo: Universitotsforlaget.

Safarewiczowa, Halina. 1960. "Forma dopełnienia blizszego w rosyjskim zdaniu zaprzeczonym: Czȩś́ II," Slavia Orientalis 4.

Simmons, Cynthia. 1981. "Cohesion in Russian: A Model for Discourse Analysis," Slavic and East_European Journal 2. 65-79.

Šaxmatov, A. A. 1925, 1927/1941. Sintaksis russkoge jazyka, 2nd ed. Leningrad: Učpedgiz.

Švedova N. Ju., et al. 1970. Grammatika sovremennoge russkoge literaturnoge jazyka. Moscow: Nauka.

Švedova N. Ju., et al. 1980. Russkaia grammatika, vol. 2. Moscow: Nauka.

Timberlake, Alan. 1975. "Hierarchies in the Genitive of Negation," Slavic and East European Journal, 19, 123-138. 
- 1982. "Invariance and the Syntax of Russian Aspect," in Tense-Asepcti between Semantics and Pragmatics, ed. Paul J. Hopper. Typological Studies in Language, vol. 1. Amsterdam-Philadelphia: John Benjamins, 305-331.

- 1987. "The Aspectual Case of Predicative Nouns in Lithuanian Texts," Unpublished manuscript, University of California, Berkeley.

Tomson, A. I. 1903. "Vinitel'nyj padež prjamogo dopolnenija v otricatel'nyx predlożenijax v russkom jazyke," Russkij filologičeskij vestnik $49,192-234$.

Underhill, Robert. 1976. Turkish Grammar. Cambridge, Mass.: MIT Press.

Vinogradov, V. V., et al. 1960. Grammatika russkege jazyka, vol. 2: Sintaksis. Moscow: Akademija Nauk.

Yokoyama, Olga. 1986. Discourse and Word Order. Pragmatics and Beyond Companion Series 6. AmsterdamPhiladelphia: John Benjamins. 